\author{
Universidade de São Paulo \\ Instituto de Física
}

\title{
Estudo e desenvolvimento de simuladores de tecido humano para utilização em fototerapia
}

\author{
Marcelo Victor Pires de Sousa
}

Banca Examinadora:

Prof. Doutora Elisabeth Mateus Yoshimura.

- Orientadora

Instituto de Física, Universidade de São Paulo.

Prof. Doutora Rosangela Itri.

Instituto de Física, Universidade de São Paulo.

Prof. Doutora Maria Cristina Chavantes.

Instituto do Coração, Faculdade de Medicina, Universidade de São Paulo.

Orientador: Prof. Dra. Elisabeth Mateus Yoshimura

Dissertação de mestrado apresentada ao Instituto de Física para a obtenção do título de Mestre em Ciências 
Dedico esse trabalho aos meus pais,

Antônio Pires de Sousa e Rosângela Maria de Sousa,

início e o fim de tudo que há de bom em mim e na minha vida. 
Como dizia Vovó Cleonice:

"Te junta aos bons e será um deles."

Por isso vim.

Como dizia Vovó Hilda:

"Fazei o bem, sem olhar a quem."

Por isso voltarei. 


\section{Agradecimentos:}

Aos meus pais e ao meu irmão, pelo amor, carinho, dedicação, apoio e por fazerem minha vida mais tranquila e feliz.

À professora doutora Elisabeth Mateus Yoshimura, não apenas por me orientar e ensinar Física, mas principalmente por ser um exemplo de cientista.

À Beth, pela dedicação, compreensão e amizade.

À toda família Sousa.

À Aninha, pelo amor e paciência dedicados a mim.

Aos meus amigos da SLC, do ATS e da UFC, por me ouvirem falar sobre Física.

Aos amigos que conheci em São Paulo, por me ouvirem falar sobre laser.

À Vivi, Kaka, Dii, Tati, Carolzinha, Clô, Kátia, Lê, Normando, Matheus, Raoni, Fabrício e demais amigos da pensão, por serem minha família em São Paulo.

À professora Emico Okuno, por ter escrito o livro que me fez vir a São Paulo e pelas várias conversas que me ensinaram muito sobre muitas coisas.

Aos colegas e amigos da Dosimetria, por tornarem o ambiente de trabalho um local de paz e tranquilidade.

Ao André, Ana Carolina, Márcia, Bruno, Lilian, por compartilharem comigo muitas horas felizes de trabalho no laboratório.

À todos do grupo de laser, por compartilharem comigo suas idéias.

Aos professores Mikiya Muramatsu e Rosângela Itri, por disponibilizarem os laboratórios.

À doutora Maria Cristina Chavantes, por dividir comigo seus conhecimentos sobre medicina, laser, a vida e tudo mais.

E finalmente, agradeço a todos que me "emprestaram" seus dedos... 


\section{SUMÁRIO}

Lista de abreviações e símbolos..............................................................

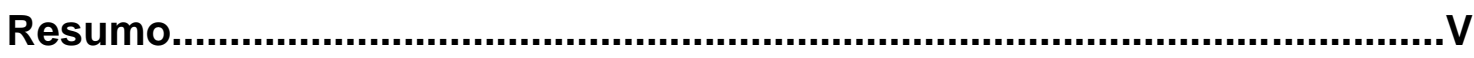

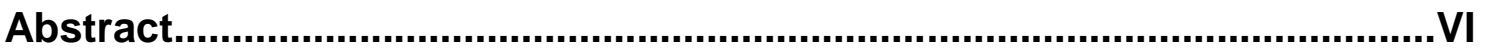

0. APRESENTAÇÃO

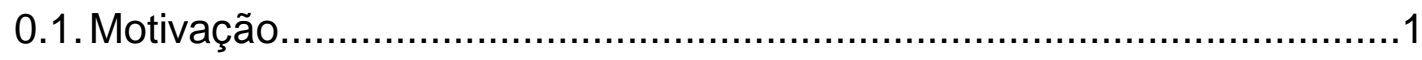

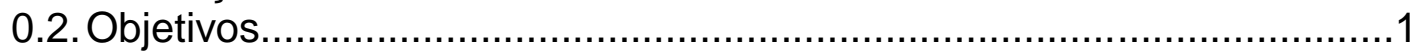

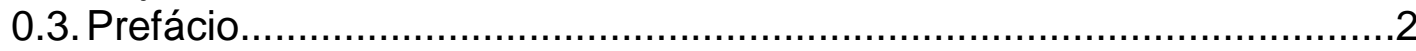

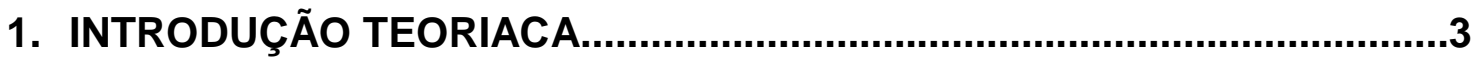

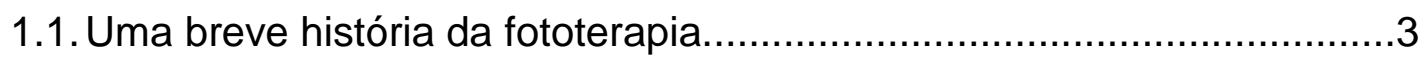

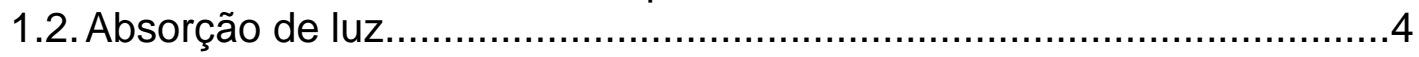

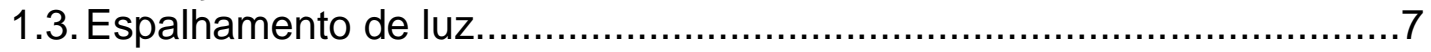

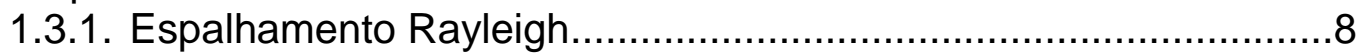

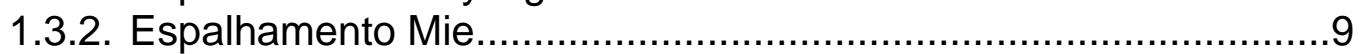

1.4. Teoria do transporte de fótons em meios turvos..................................10

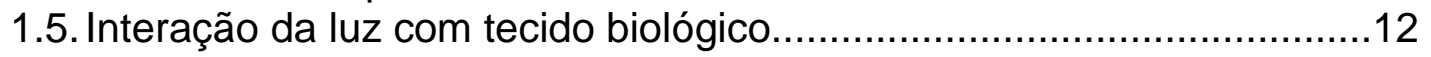

1.5.1. Biomodulação......................................................................14

1.5.2. Terapia Fotodinâmica.........................................................15

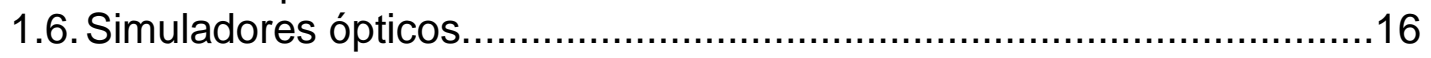

1.7. Aplicações do laser na área da saúde....................................................18

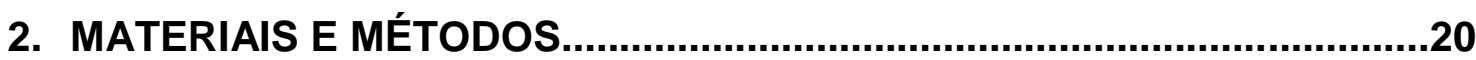

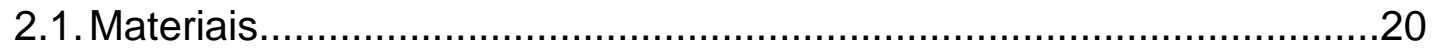

2.2. Características dos lasers, câmeras e equipamentos de medida...........21

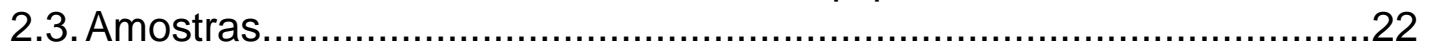

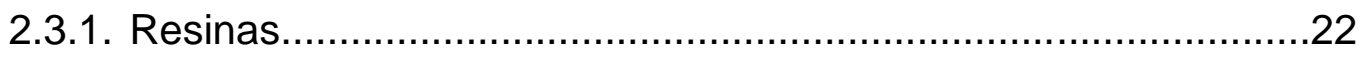

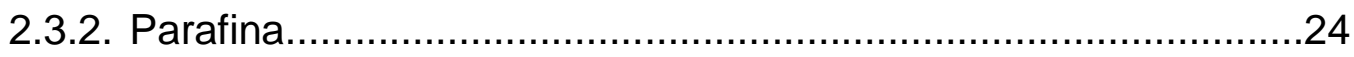

2.3.3. Melanina diluída em água.....................................................24

2.3.4. Procedimentos de manufatura das amostras.............................25

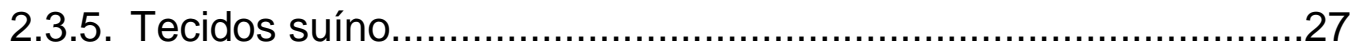

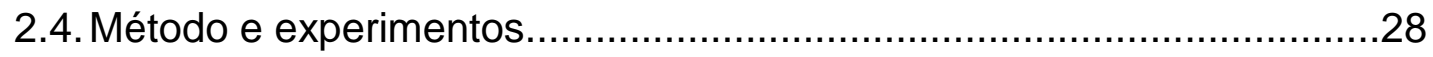

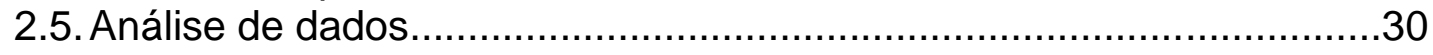

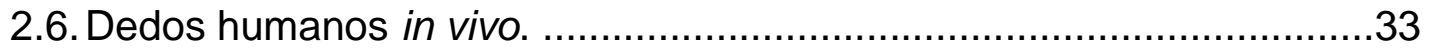

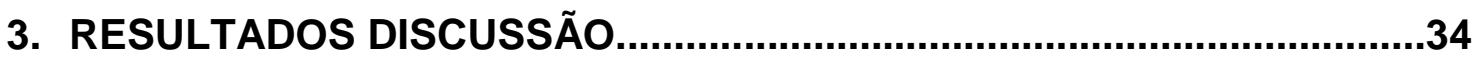

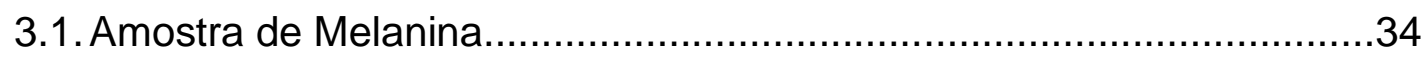

3.2. Amostras de resina com $\mathrm{Al}_{2} \mathrm{O}_{3}$ alfa como espalhador...........................36

3.2.1. Transmissão.................................................................... 


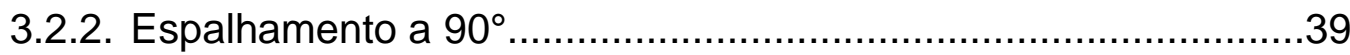

3.3. Amostras de resina com $\mathrm{Al}_{2} \mathrm{O}_{3}$ gama como espalhador........................41

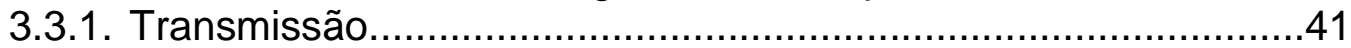

3.4. Amostras de resina com Microesferas de Vidro.................................44

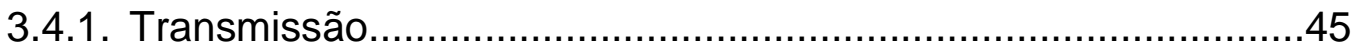

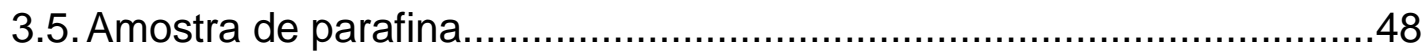

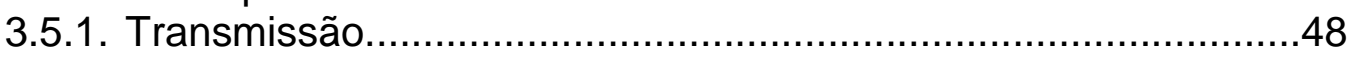

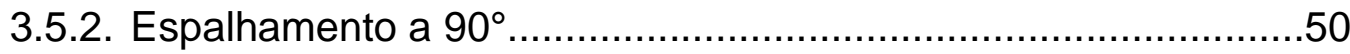

3.6. Tecido Suíno.............................................................................

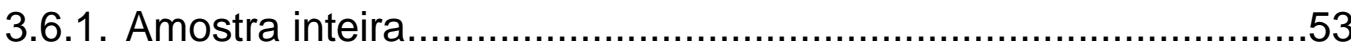

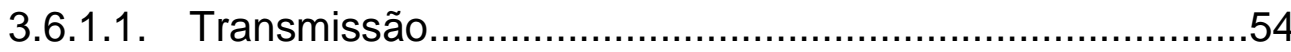

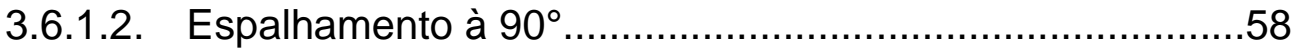

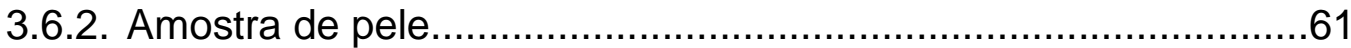

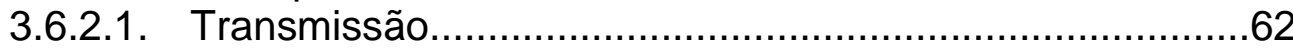

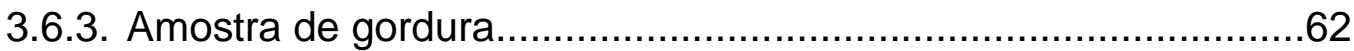

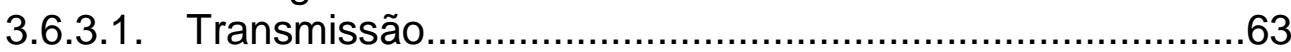

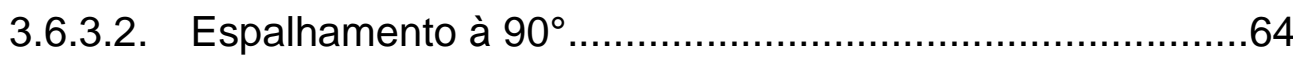

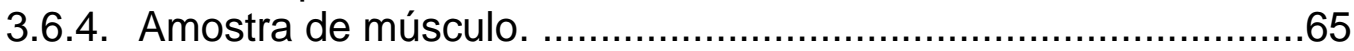

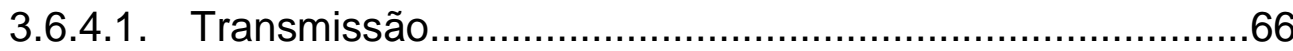

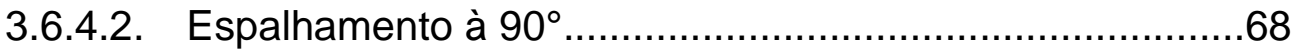

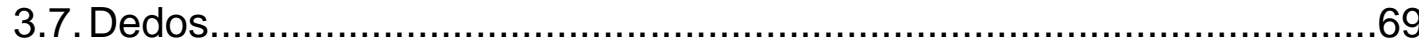

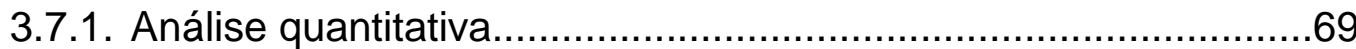

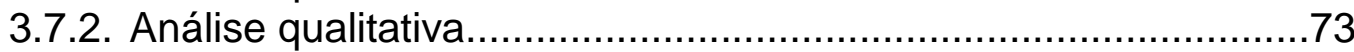

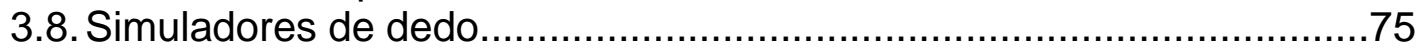

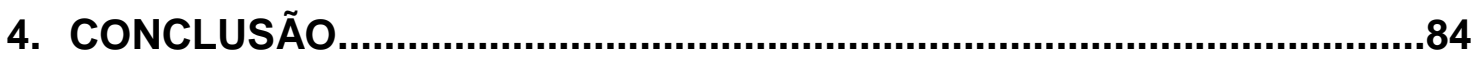

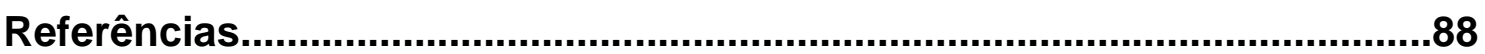




\section{Resumo:}

Uma das dificuldades da dosimetria na área de Terapia com Laser de Baixa Intensidade (TLBI) é conhecer a distribuição da luz nos tecidos biológicos. Esse conhecimento pode ser obtido com o uso de materiais que simulem as características ópticas dos tecidos. O objetivo desse trabalho é produzir e avaliar simuladores (phantoms) sólidos em formato semelhante a dedos. Para construí-los as partículas espalhadoras testadas foram $\mathrm{Al}_{2} \mathrm{O}_{3}$ alfa, $\mathrm{Al}_{2} \mathrm{O}_{3}$ gama e microesferas de vidro, e diversas tintas foram avaliadas como absorvedores. As partículas e tintas foram adicionadas a resinas transparentes e parafina. Tecidos de suíno foram experimentados e foi possível avaliar qualitativamente as características de absorção e espalhamento de pele, músculo e tecido adiposo. Objetivando estudar in vivo a distribuição da luz, dedos de 48 voluntários foram iluminados e o padrão da luz que atravessa esses dedos foi quantificado levando em consideração os tons de pele e as espessuras. Comparando as amostras não biológicas estudadas com os tecidos suínos, concluímos que a parafina tingida simula bem a difusão causada por pele e que a resina com $10 \%$ de nano partículas de $\mathrm{Al}_{2} \mathrm{O}_{3}$ simula 0 espalhamento gerado por tecido adiposo. A partir desses dados foram confeccionados seis simuladores de dedos: três pequenos $(14 \mathrm{~mm})$ e três grandes $(18 \mathrm{~mm})$, em três tons de pele. Concluímos que os dedos e os simuladores apresentaram características de absorção e espalhamento semelhantes. Esses simuladores poderão ser usados na prática clínica com a finalidade de otimizar tratamentos em LBI e PDT. 


\section{Abstract:}

One of difficulties on dosimetry for Low Level Laser Therapy is to know the light distribution inside the illuminated tissue. This knowledge can be obtained with the use of materials that simulate the optical properties of tissues. The aim of this work is to produce and evaluate solid finger shaped phantoms. To build the phantoms, the scattering particles tested were alpha and gamma $\mathrm{Al}_{2} \mathrm{O}_{3}$ and glass microspheres. Various inks were evaluated as absorbers. The particles and inks were added to transparent resins and paraffin. Swine tissues were tested and it was possible to qualitatively evaluate the scattering and absorption characteristics of skin, muscle and adipose tissue. To study light distribution in vivo, fingers of 48 volunteers were illuminated and the pattern of light transmitted through these fingers was quantified taking into accounts the skin tones and thicknesses. Comparing the non-biological samples with the swine tissues one can conclude that the dyed paraffin simulates the diffusion and absorption caused by skin and that the resin with alpha $\mathrm{Al}_{2} \mathrm{O}_{3}$ nanoparticles $(10 \%)$ simulates the scattering generated by fat. According to this information, six finger simulators were made, three of them of small size $(14 \mathrm{~mm})$ and three of them of large size $(18 \mathrm{~mm})$; for each size, each simulator has a different skin tone. The fingers and simulators showed similar absorption and scattering characteristics. These simulators can be used in clinical practice in order to optimize LLLT and PDT treatments. 


\section{APRESENTAÇÃO:}

\subsection{Motivação.}

O laser na Medicina vem sendo utilizado com eficácia comprovada há anos. No entanto, as Terapias com Laser de Baixa Intensidade (TLBI) e terapia fotodinâmica (PDT) ainda carecem de protocolos dosimétricos bem estabelecidos. Está claro para pesquisadores e clínicos que utilizam laser que características individuais, como cor da pele e espessura de tecidos biológicos, podem influenciar nos parâmetros dosimétricos para TLBI e PDT. Em decorrência disso muitos tratamentos que funcionam para algumas pessoas têm sua eficácia diminuída ou até mesmo anulada para outras.

A principal motivação para esse trabalho é a busca da solução, ou pelo menos, da redução desses problemas. Para isso foram desenvolvidos simuladores que poderão auxiliar os pesquisadores e clínicos a desenvolver, otimizar e adaptar fototerapias. Os simuladores possibilitam testes mais controláveis e reprodutíveis.

\subsection{Objetivos.}

O objetivo desse trabalho é desenvolver, avaliar e comparar simuladores (phantoms) sólidos em formato semelhante a dedos. Para isso é necessário:

1) Estudar a difusão da luz em meios turvos, como os tecidos biológicos.

2) Testar partículas que espalhem a luz tais como $\mathrm{Al}_{2} \mathrm{O}_{3}$ alfa, $\mathrm{Al}_{2} \mathrm{O}_{3}$ gama e microesferas de vidro. 
3) Avaliar diversas tintas para servirem como absorvedores ou simuladores de melanina.

4) Avaliar qualitativamente tecidos biológicos, para isso será utilizado tecido suíno.

5) Iluminar dedos humanos in vivo levando em consideração os tons de pele e as diversas espessuras dos dedos.

6) Confeccionar o simulador e compará-lo aos dedos.

\subsection{Prefácio.}

Essa dissertação pretende ser fonte de pesquisa para os que querem saber mais sobre laser em Biomedicina, interação da luz com meios turvos (principalmente tecidos biológicos), e desenvolvimento de simuladores ópticos para laserterapia.

No capitulo 1, são apresentadas as bases teóricas nas quais esse trabalho se fundamenta.

No capitulo 2, discorre-se sobre os materiais que compõem as amostras ensaiadas, bem como sobre os experimentos feitos com essas amostras e a forma de avaliar os resultados obtidos.

No capitulo 3, são exibidos os resultados e as ponderações relativas a eles.

No capitulo 4, formulam-se de forma sucinta as conclusões. 


\section{INTRODUÇÃO TEÓRICA:}

\subsection{Uma breve história da fototerapia.}

Qual o primeiro ser humano a utilizar luz para curar? Em qual momento de nossa história foi dada a partida na tão moderna laserterapia? Pensando de forma simples poderíamos dizer que essa é uma história que começa com Theodore H. Maiman e o primeiro laser (Perkowitz, 2010). Mas, vendo de forma mais profunda, a luz para ajudar a curar enfermidades foi utilizada desde tempos imemoriais. Em textos antigos podem-se encontrar referências à utilização da luz para melhorar a saúde e o ânimo das pessoas. Sun Tzu (Sun Tzu, IV a.C.) em A Arte da Guerra recomenda expor-se ao sol após as batalhas para ajudar na cicatrização das feridas; na Grécia antiga, bem como no Egito e na China, a exposição ao sol era tida como benéfica à saúde (Roelandts, 2002).

Durante a Idade Média tais conhecimentos ficaram esquecidos, mas no fim do século XIX essas idéias foram retomadas e eram comuns, na Europa, os banhos de sol terapêuticos. Na segunda metade do século XIX, experimentos in vivo foram largamente realizados na fotomedicina, e descobriu-se que diferentes cores levam a diferentes estímulos biológicos (Gorbachewich, 1883; Jung, 1878). No início do século XX, Finsen tratou várias enfermidades dermatológicas utilizando luz (Finsen, 1899); Raab fez os primeiros experimentos em Terapia Fotodinâmica (PDT, do inglês Photodynamic Therapy) (Chavantes, 2009); e Von Tappeiner e Jesionek usaram PDT para tratamento de câncer de pele (Tappeiner, 1900). 
As bases teóricas do LASER (Light Amplification by Stimulated Emission of Radiation) foram postuladas por Albert Einstein em 1916 (Einstein, 1916), no entanto, só em 1960, Theodore Maiman (Maiman, 1960) desenvolveu o primeiro laser. Ainda nos anos 1960 o laser de alta potência (LAP) foi usado em cirurgias possibilitando ressecções mais precisas e menos invasivas.

Os primeiros efeitos cicatriciais do Laser de Baixa Intensidade (LBI) foram observados por Mester no fim da década de 1960, por isso ele é considerado o Pai da Laserterapia (Mester, 1973). Por mais de 20 anos os efeitos do LBI foram desacreditados por grande parte da comunidade científica até que os trabalhos in vivo e in vitro realizados por Karu e colaboradores (Karu et al, 1988)decifraram e descreveram o efeito fotofisicoquímico do LBI em termos celulares e moleculares, por isso Karu é considerada a Mãe da Laserterapia.

Atualmente, tanto o LAP quanto o LBI são ferramentas comuns em muitas áreas da Medicina; por isso torna-se cada vez mais importante 0 desenvolvimento da dosimetria para esses tipos de tratamentos (Yoshimura e Itri, 2007).

Ainda não existe consenso sobre qual grandeza é a mais apropriada para quantificar a dose em laserterapia. No entanto, a grandeza mais utilizada para isso é a fluência, que é definida como a energia por unidade de área que incide de todas as direções sobre a superfície de uma esfera de tamanho infinitesimal (Sliney, 2007). 
1.2 Absorção de luz. (Niemz, 2004)

Ao atravessar um meio material as ondas eletromagnéticas interagem com as moléculas sendo, portanto, atenuadas. Uma das formas de interação é a absorção, na qual um fóton é usado para levar a molécula a um nível energético mais elevado. Quando um fóton incide no meio, ele pode ser absorvido por uma molécula ou átomo e ter sua energia transformada em energia cinética da molécula ou do átomo; gerar mudança conformacional da molécula ou ainda ionizar o meio com a retirada de um elétron.

O processo de absorção é evidenciado experimentalmente pela diminuição na intensidade da Onda Eletromagnética (OEM). Em um meio material idealizado, no qual só há o processo de absorção, a intensidade luminosa decresce exponencialmente, essa é a lei de Lambert-Beer, que é expressa na equação (1.1).

$$
I=I_{0} e^{-\mu_{a} z}=I_{0} e^{-k c z}
$$

Em (1.1), $\mu_{a}\left(\mathrm{~cm}^{-1}\right)$ é o coeficiente de absorção do material, $c$ a concentração de cromóforos no meio, $z$ é o caminho óptico da luz e $k$ é um coeficiente que depende do material e de $\lambda$.

A Transmitância $(T)$ de um meio é definida como a razão da intensidade luminosa transmitida através desse meio e a intensidade incidente.

$$
T=\frac{I}{I_{0}} \text { e, para um meio absorvedor, } T=e^{-k c z}
$$

A absorbância $(A)$ do meio material depende fortemente, e de forma complexa, do comprimento de onda incidente, e é definida como: 
$A=\log \left(\frac{1}{T}\right)=-\log (T)$, e, para um meio absorvedor, $A=k c z \log (e)$

Quando a absorbância é pequena em um dado comprimento de onda dizemos que o material é transparente nessa faixa do espectro, do contrário dizemos que ele é opaco para essa dada frequência. Não é conhecido material que seja ou opaco ou transparente para todo o espectro eletromagnético. Tecidos biológicos apresentam uma grande variedade quanto ao espectro de absorção i.e. para um mesmo comprimento de onda os tecidos apresentam absorbâncias diferentes, dependo da composição molecular do tecido. A córnea é muito transparente para a faixa visível e opaca para o infravermelho (IV) o que é explicado pela grande quantidade de água em sua composição. Já a pele apresenta alta absorbância na faixa do visível devido à melanina (Niemz, 2004).

A maior parte da absorção, nos tecidos biológicos, é ocasionada pela água ou por macromoléculas, como proteínas e melanina. A água é a principal responsável pela absorção no infravermelho e as proteínas pela faixa UV do espectro. Os espectros de absorção de algumas substâncias de interesse clínico estão na figura 1.1. 


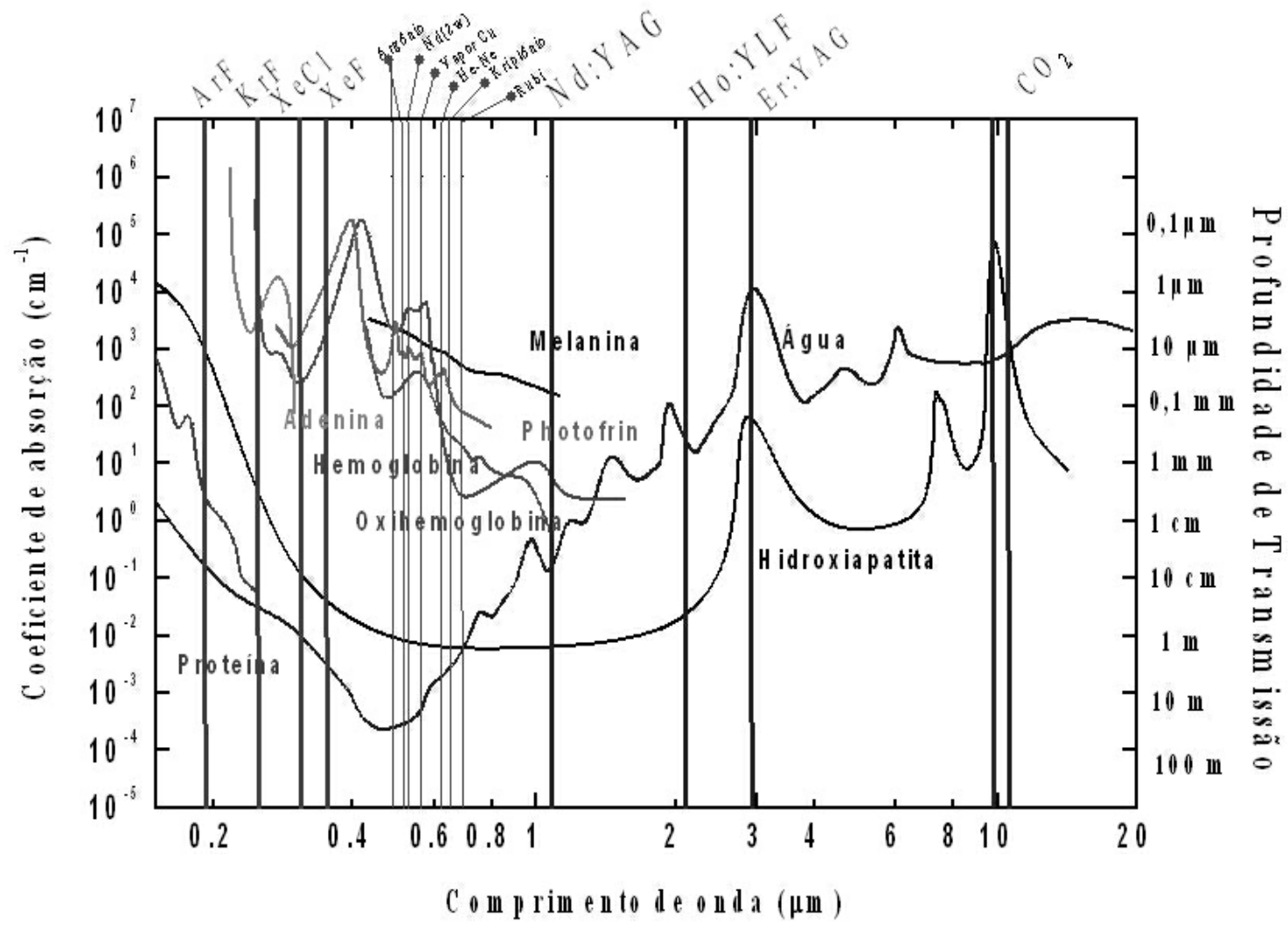

Figura 1.1: Variação de $\mu_{\mathrm{a}}$ e a profundidade de transmissão para proteína, adenina, hemoglobina, oxihemoglobina, photofrin, melanina, água e hidroxiapatita em função de $\lambda$. No eixo superior estão indicados comprimentos de onda de alguns lasers de uso médico.

$\mathrm{Na}$ faixa do vermelho e IV próximo tanto a água quanto as macromoléculas absorvem relativamente pouco, possibilitando uma maior penetração da luz nos tecidos. Por isso, a faixa de $600 \mathrm{~nm}$ a $1200 \mathrm{~nm}$ é bastante empregada para tratamentos em tecidos mais profundos e é, portanto, considerada como uma "janela terapêutica". (figura 1.2) 


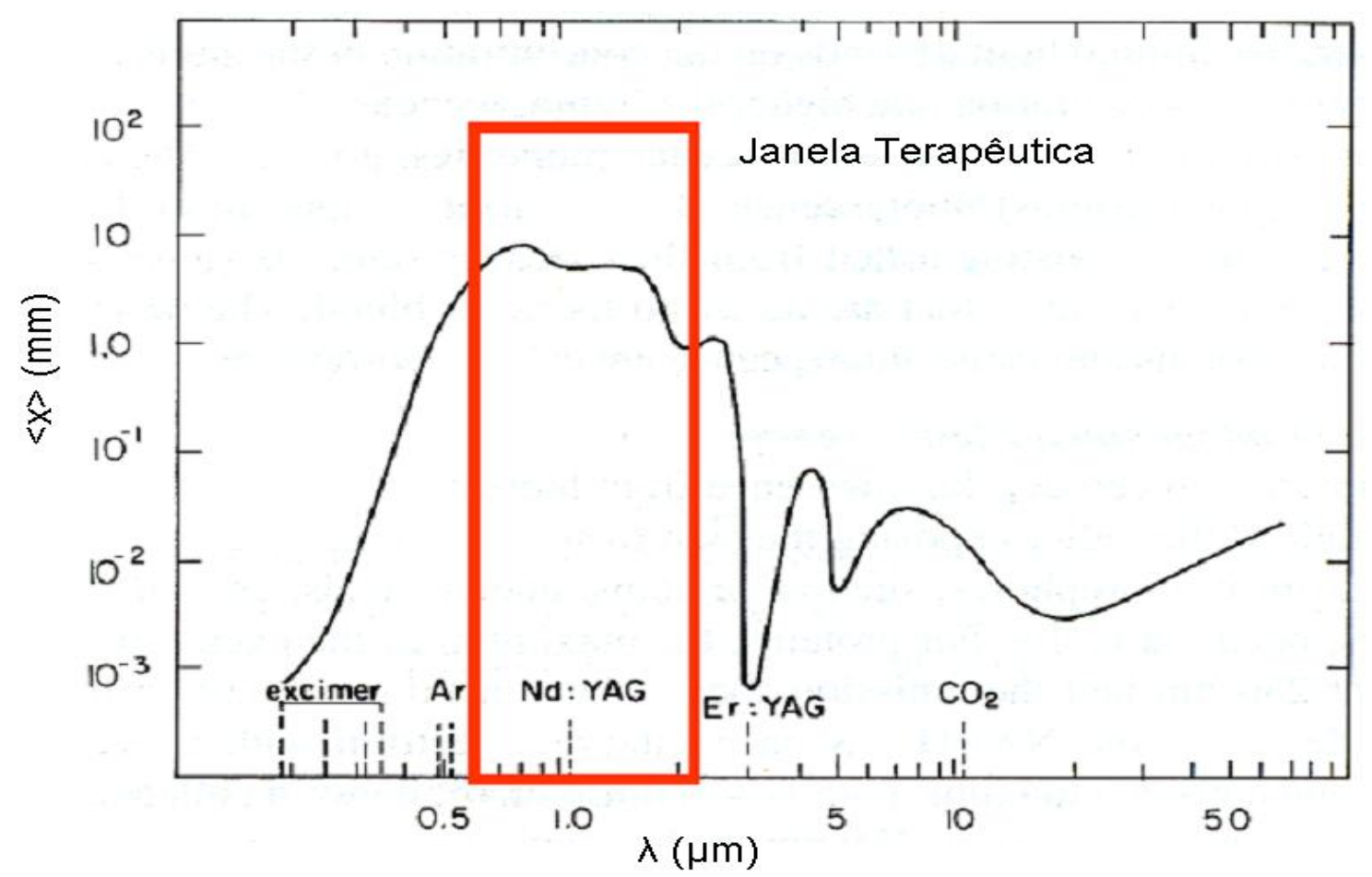

Figura 1.2: Estimativa da média de profundidade que os fótons atingem em tecidos biológicos, $<x>$.

1.3 Espalhamento de luz. (Johnson, 1974)

Para a maioria dos tecidos biológicos o principal fator de atenuação da intensidade do feixe é o espalhamento dos fótons (Cheong, 1990). Esse espalhamento é devido às moléculas do material e às superfícies de diferentes estruturas alvo. O espalhamento pode ser dividido basicamente em dois tipos: elástico, no qual o fóton apenas muda de direção, e inelástico, onde há mudança de energia do fóton. Dois modelos podem ser usados para explicar o espalhamento elástico: espalhamentos Rayleigh e Mie.

\subsubsection{Espalhamento Rayleigh:}

O espalhamento Rayleigh acontece quando o tamanho (d) do centro espalhador é muito menor que o comprimento de onda $(\lambda)$ incidente. Para esse 
tipo de espalhamento a razão entre as médias temporais da intensidade espalhada e incidente, esta é obtida pela equação de espalhamento Rayleigh e independe da forma do centro espalhador.

$$
\frac{\left\langle I_{s}\right\rangle}{\left\langle I_{0}\right\rangle} \propto \frac{\operatorname{sen}^{2}(\theta)}{\lambda^{4} r^{2}}
$$

Em (1.4), $\theta$ é o ângulo entre a direção de oscilação do campo elétrico e o vetor posição $\boldsymbol{r}$ (figura 1.3). A variação $\operatorname{com} \operatorname{sen}^{2}(\theta)$ deixa clara a tendência de espalhamento frontal e retroespalhamento, e a baixa probabilidade de luz espalhada em direções perpendiculares à direção de propagação (figura 1.4). Como era de se esperar a intensidade diminui quadraticamente com a distância do observador à fonte $(r)$. Para esse tipo de interação o espalhamento depende do inverso da quarta potência de $\lambda$. Esse é o espalhamento predominante na atmosfera terrestre e explica a cor azul do céu, pois a luz azul é a mais espalhada do espectro visível (Rayleigh, 1871).

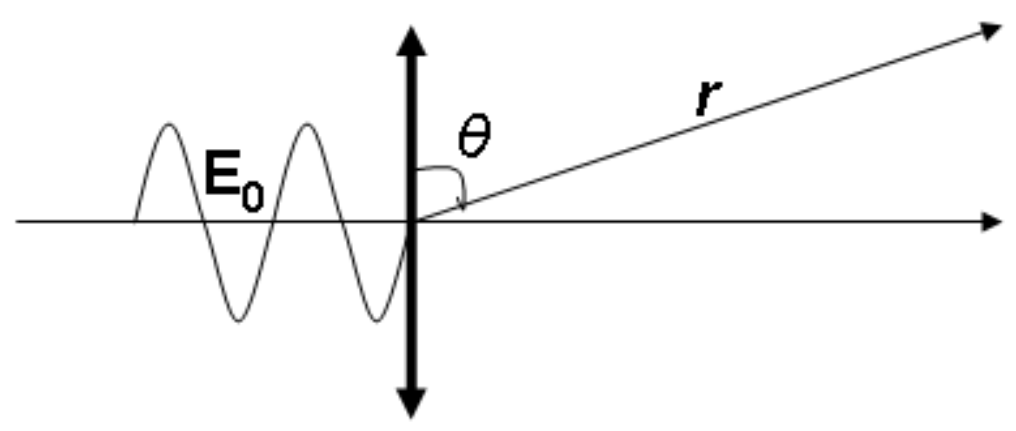

Figura 1.3: Propagação da OEM e ângulo de espalhamento.

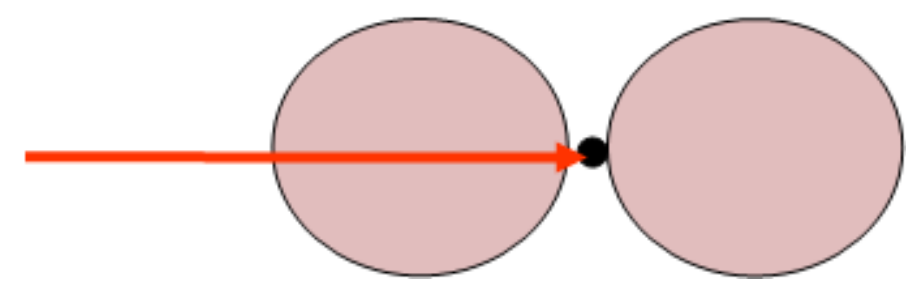

Figura 1.4: Padrão do espalhamento no modelo Rayleigh. A seta representa a direção de incidência dos fótons. 


\subsubsection{Espalhamento Mie:}

As interações elásticas dependem de tamanho e forma dos centros espalhadores. A solução para o espalhamento de uma OEM plana por uma esfera uniforme e isotrópica foi obtida por Mie em 1908 (Mie, 1908). O problema do espalhamento da luz é muito complexo por isso uma solução analítica só é possível para poucas geometrias dos centros espalhadores (Kerker, 1969).

A principal consequência da interação da luz com uma partícula com $d \sim \lambda$ é a atenuação da intensidade espalhada devido à interferência entre ondas parciais de luz espalhada por diferentes pontos da partícula (Johnson, 1974). O espalhamento Mie depende fracamente do comprimento de onda $\left(\lambda^{-x} \operatorname{com} 0,4<x<0,5\right)$ e é predominantemente frontal (figura 1.5).

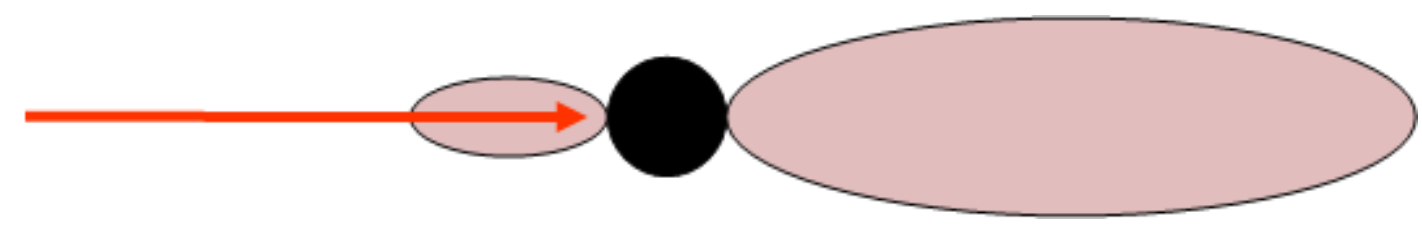

Figura 1.5: Padrão do espalhamento no modelo Mie.

1.4 Teoria do transporte de fótons em meios turvos. (Ishimaru, 1978)

Os meios em que tanto a absorção quanto o espalhamento são relevantes são chamados de meios turvos. Uma abordagem analítica, da interação da OEM com esse meio usando as leis de Maxwell é inviável devido à extrema complexidade do problema. E até mesmo uma solução por métodos 
numéricos não é desejável devido ao imenso número de vezes que as equações teriam que ser empregadas (Prahl, 1988).

Para resolver o problema da propagação da luz através de meios turvos foi desenvolvida a teoria do transporte de fótons (Ishimaru, 1978). Essa abordagem explicita a conservação do número de fótons e por trás disso está o princípio de conservação da energia.

A radiância $(L)$ é a intensidade luminosa em uma dada direção.

$$
d L=\frac{d I}{d \Omega}
$$

De acordo com a teoria do transporte de fótons a radiância no ponto definido pelo vetor posição $\mathbf{r}$, na direção $\mathbf{s}, L(\mathbf{r}, \mathbf{s})$ é atenuada devido à absorção e ao espalhamento, e sendo aumentada devido aos fótons que se propagavam em uma direção qualquer s', os quais tiveram sua direção alterada por espalhamento para a direção s.

$$
\frac{d L(\mathbf{r}, \mathbf{s})}{d s}=-\left(\mu_{t}\right) L(\mathbf{r}, \mathbf{s})+\mu_{s} \int_{4 \pi} p\left(\mathbf{s}, \mathbf{s}^{\prime}\right) L(\mathbf{r}, \mathbf{s}) d \Omega^{\prime}
$$

Onde, $\mu_{\mathrm{s}}\left(\mathrm{cm}^{-1}\right)$ é o coeficiente de espalhamento, $\mu_{\mathrm{t}}\left(\mathrm{cm}^{-1}\right)$ é o coeficiente de atenuação total, $\left(\mu_{t}=\mu_{\mathrm{a}}+\mu_{\mathrm{s}}\right) ; p\left(\mathbf{s}, \mathbf{s}^{\prime}\right)$ é o fator de fase, que quando normalizado é tal que:

$$
\int_{4 \pi} p\left(\mathrm{~s}, \mathrm{~s}^{\prime}\right) d \Omega^{\prime}=1
$$

se torna a função densidade de probabilidade do espalhamento da direção s' para a direção s. Para tornar o problema tratável admitimos que $p\left(\mathbf{s}, \mathbf{s}^{\prime}\right)$ depende apenas do ângulo entre $\mathbf{s}$ e s' que denotaremos por $\psi$. 
Normalmente $p\left(\mathbf{s}, \mathbf{s}^{\prime}\right)$ não é conhecido, e trabalhamos com o fator de anisotropia (g), dado por:

$$
g=\int_{4 \pi} p(\psi) \cos \psi d \Omega^{\prime}
$$

Da equação (1.8) vemos que $g$ tende para 1,0 ou -1 quando 0 espalhamento é frontal, isotrópico ou retroespalhado, respectivamente (figura 1.6). Para a maioria dos tecidos biológicos $0,70<\mathrm{g}<0,99$. (Cheong, 1990; Niemz, 2004)
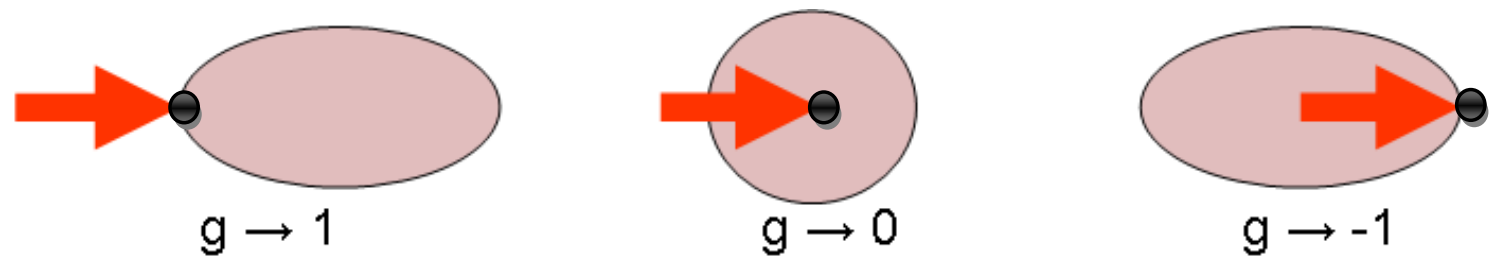

Figura 1.6: Padrão de espalhamento para $g$ tendendo a 1 , 0 e -1 , respectivamente.

\subsection{Interação da luz com tecido biológico.}

Os lasers são considerados de alta potência quando operam com uma potência acima de $1 \mathrm{~W}$. O LAP é usado principalmente em cirurgias por isso também recebe o nome de laser cirúrgico. Os lasers são considerados de baixa intensidade quando operam com uma potência inferior a $1 \mathrm{~W}$ e não geram aumento de temperatura no tecido superior a $1^{\circ} \mathrm{C}$. Logo, a ação terapêutica desse tipo de laser não se deve a um efeito fototérmico e sim a efeitos biomoleculares (Chavantes, 2009).

A enorme variedade de tecidos bem como a imensa variedade de intensidades, comprimentos de onda e formas de emissão dos diversos tipos 
de laser propiciam muitos efeitos e consequências para a interação lasertecido, como pode ser visto na tabela 1.1 (Chavantes, 2009).

Tabela 1.1: Efeito e consequências da interação laser-tecido..

\begin{tabular}{|c|c|c|}
\hline Tipo de Laser & $\begin{array}{c}\text { Efeito do Laser no Tecido } \\
\text { Biológico }\end{array}$ & Alterações observadas \\
\hline & Fototérmico & Coagula, Carboniza \\
LAP & $\begin{array}{c}\text { Fotomecanicoacústico } \\
\text { Fotoablativo }\end{array}$ & $\begin{array}{c}\text { Corta com Precisão } \\
\text { Remove Tecido com Precisão } \\
\end{array}$ \\
Fotoionizante & Retira elétrons \\
\hline LBI & Fotofisicoquímico & Biomodulação, PDT \\
\hline
\end{tabular}

Os efeitos térmicos da interação laser-tecido e as temperaturas que os tecidos chegam a atingir no momento da interação, no local da interação estão listados na tabela 1.2.

Tabela 1.2: Efeitos fototérmicos da interação laser-tecido. (Niemz, 2004)

\begin{tabular}{|l|l|l|}
\hline Efeito Térmico & Temperatura & Aplicação na área clínica \\
\hline Hipertermia & $<45^{\circ} \mathrm{C}$ & Analgesia \\
Soldadura & $45^{\circ} \mathrm{C}-60^{\circ} \mathrm{C}$ & Selamento da Retina \\
Coagulação & $60^{\circ} \mathrm{C}-100^{\circ} \mathrm{C}$ & Redução de Hemorragias \\
Vaporização & $>100^{\circ} \mathrm{C}$ & Geralmente Indesejado \\
Carbonização & $100^{\circ} \mathrm{C}$ & Remoção de tecido \\
Ablação & $\sim 100^{\circ} \mathrm{C}$ & Cirurgias \\
Corte & $\sim 1500^{\circ} \mathrm{C}$ & Microcirurgias \\
\hline
\end{tabular}

As densidades de potência e os tempos de duração dos pulsos para os diversos tipos de laser chegam a variar 18 ordens de grandeza, no entanto as densidades de energia variam relativamente pouco, como pode ser visto na figura 1.7, na qual as condições em que ocorrem os efeitos estão apenas aproximadamente delimitadas pelos círculos. 


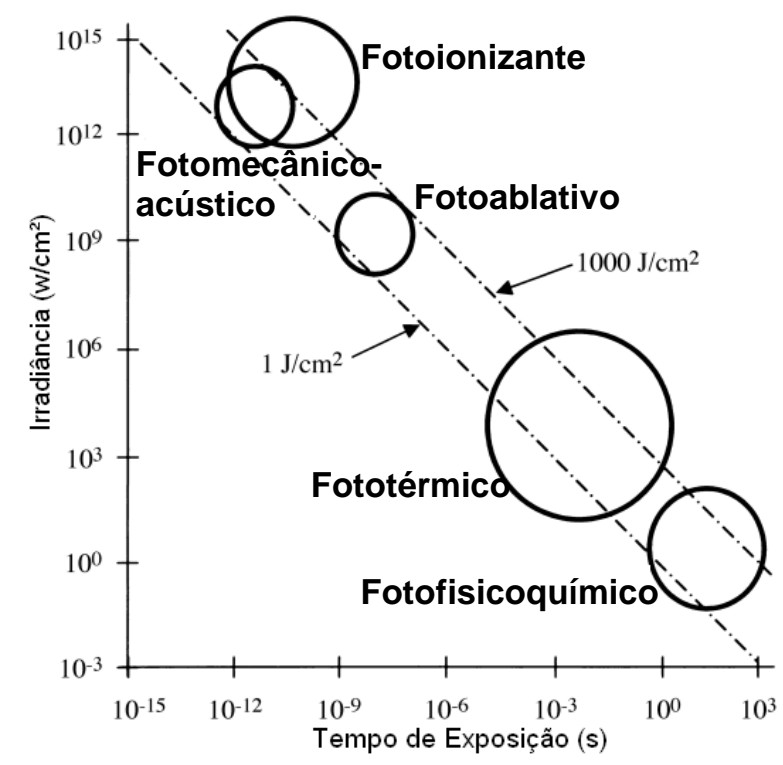

Figura 1.7: Mapa das interações laser-tecido. Modificado de Boulnois, 1986.

\subsubsection{Biomodulação.}

Atualmente os tratamentos com laser, principalmente $\mathrm{LBI}$, têm se difundido entre as mais diversas áreas da Medicina. Desde sua invenção, em 1960, o laser é considerado um equipamento com grande potencial em tratamentos médicos. A bioestimulação é muito utilizada para reduzir a inflamação e edemas, melhorando cicatrização e reparação tecidual; reduzir inflamação, edemas e propiciar a drenagem linfática. A bioinibição é eficaz no tratamento de dores agudas e crônicas bem como na contenção da hipertrofia celular (Chavantes, 2009).

O mecanismo biomolecular que ocorre no interior das células foi explicado por Karu em 1989 (Karu, 1989). Os processos celulares estimulados pelo laser acontecem quando os fótons são absorvidos pela membrana celular e/ou mitocondrial, ou pelo cromóforo endógeno citocromo-C oxidase. Os fótons absorvidos por componentes da cadeia respiratória desencadeiam uma 
sucessão de reações bioquímicas que aumentam o gradiente de prótons e o potencial elétrico de membrana. Há um aumento da concentração de ATP e do potencial redox, em seguida ocorre oxidação de NADH mitocondrial, levando a mudança no NADH citoplasmático. Então, enzimas do canal de sódio da membrana aumentam a relação entre sódio e hidrogênio, com crescimento da concentração da enzima sódio potássio ATPase, ocasionando a diminuição da concentração de íons de hidrogênio. Consequentemente, ocorrem variações na concentração de cálcio intracelular e AMPc, que são marcadores para a síntese de ácidos nucléicos. Logo é possível concluir que o LBI pode acelera o processo metabólico celular, podendo ativar a proliferação celular e melhorar a cicatrização.

Os fotoaceptores primários do LBI são componentes da cadeia respiratória, isso explica a universalidade das aplicações desse tipo de laser. Os efeitos de bioestimulação acorrem com doses muito baixas, já que o estímulo luminoso é apenas o gatilho para levar a célula à homeostase. Segundo Basford (Basford, 1989), da TLBI também resultam efeitos sistêmicos, sobretudo aumento da imunidade do organismo.

\subsubsection{Terapia Fotodinâmica:}

A Terapia Fotodinâmica parte do princípio de que a interação de luz de comprimento de onda adequado com um composto não tóxico, fotosensitizador (FS), e na presença de oxigênio molecular resultam em Espécies Reativas de Oxigênio (ROS) capazes de inviabilizar células (Machado, 2000). 
A principal aplicação da PDT é a destruição de células tumorais ou neoplásicas, como também é usado para tratar infecções bacterianas e fúngicas. O FS pode ser aplicado de forma tópica, ingerido, inalado ou injetado na corrente sanguínea. As propriedades desejáveis de um FS são:

1) Baixa toxidade quando inativado.

2) Retenção muito maior em células malignas que em células sadias.

3) Ativação por um comprimento de onda particular.

4) O FS ativado causa a destruição celular. (Katzir, 1993)

Os principais tipos de FS são os Derivados de Hematoporfirinas (HpD) e as clorinas, que apresentam picos de absorção entre $(350-400 \mathrm{~nm})$ e (630 - $700 \mathrm{~nm}$ ), respectivamente.

Há dois mecanismos de ação da PDT: no tipo 1 há formação de radicais livres que levam a morte celular. No tipo 2 há formação de oxigênio singleto excitado, que é altamente reativo, e leva à oxidação e consequentemente a morte da célula.

A PDT pode ser dividida, para um melhor entendimento, em 5 etapas: adição de FS; acúmulo de FS nas células tumorais; irradiação; produção de radicais livres; e morte celular, como pode ser visto na figura 1.8 para o $\mathrm{HpD}$.

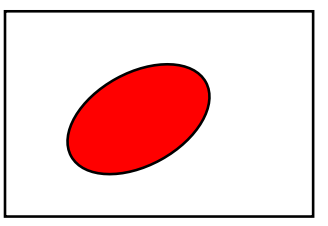

Tumor

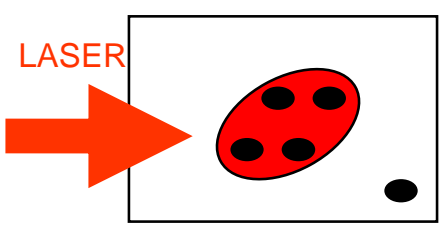

Irradiação

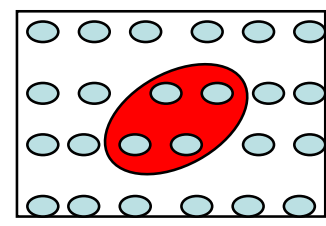

Adição de $\mathrm{HpD}, \mathrm{t}=0$

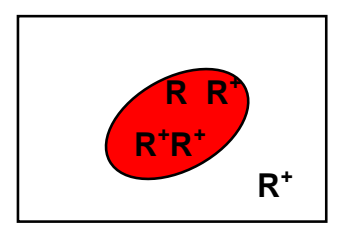

Formação de Radicais livres, minutos a dias após irradiação

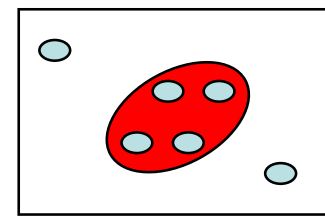

Acúmulo, $\mathrm{t}=$ horas

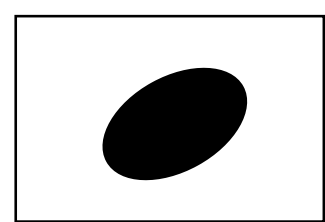

Apoptose, horas a dias após irradiação

Figura 1.8: Etapas da PDT. Adaptado de Niemz, 2004. 


\subsection{Simuladores ópticos.}

Os simuladores ópticos de tecidos biológicos têm uma série de finalidades, entre elas podemos destacar:

1. Testes iniciais de tratamentos (Pogue, 2006).

Um dos problemas enfrentados por clínicos ao iniciar um novo tipo de tratamento é saber quais regiões e tecidos estão sendo iluminados e com qual intensidade. Portanto, os simuladores de tecido são úteis para avaliar a fluência através de um dado tecido.

2. Modificação ou adaptação de tratamentos.

Um simulador de pele pode ser usado para auxiliar a conversão de um tratamento de um dado grupo de pacientes a outro com outro fenótipo.

3. Fazer controle de qualidade de equipamentos.

O simulador é usado para comparar outros equipamentos em teste com um equipamento padrão. Esses equipamentos podem ser o próprio laser, ou algum componente do sistema de detecção.

4. Comparar performances entre equipamentos.

O simulador é usado para avaliar qual equipamento é mais viável para cada aplicação ou tratamento. É, portanto, interessante usar o simulador para avaliar qual deverá ser o laser usado em uma nova terapia.

O desenvolvimento de simuladores ópticos (visível e infravermelho próximo) teve início nos anos 1980 e foi impulsionado pela técnica de imageamento do seio para detecção de tumores chamada de diafanográfia (Watmough, 1982). Com o avanço da terapia fotodinâmica (PDT) se tornou necessário o desenvolvimento de simuladores com características de absorção 
tanto dos tecidos, fluoróforos endógenos (NADH e FAD), como dos fluoróforos exógenos, tais como porfirinas e cianinas (Pogue, 2006). Os simuladores têm um papel central no planejamento das terapias usando laser. A utilização da luz na Medicina aumentou e se diversificou consideravelmente nos últimos anos, portanto a otimização dos diversos tratamentos tem importância cada vez maior.

\subsection{Aplicações do laser na área da saúde.}

A primeira aplicabilidade Medica do laser foi na Oftalmologia, e, ainda hoje, a maior parte dos lasers é usada nessa área. Logo em seguida a Odontologia adotou essa tecnologia. Vários tipos de tumores são combatidos com PDT ou tratamentos fototérmicos induzidos por laser. Com o desenvolvimento da instrumentação para cirurgias minimamente invasivas, a utilização do laser em cirurgias de coração e pulmão se torna cada vez mais comum (Chavantes, 2009).

Os tratamentos com LBI são frequentemente usados para redução da inflamação e da dor; e aceleração do processo de cicatrização. A biomodulação é um processo celular, tissular e sistêmico, por isso pode ser usada nos mais variados casos clínicos.

A contribuição da TLBI tem sido divulgada na literatura médica para 0 tratamento de inúmeras enfermidades. É um método relativamente novo que vem sendo empregado em diversas áreas de Ciências da Saúde, como mostra a tabela 1.3. 
Tabela 1.3: Exemplos de enfermidades ou condições patológicas nas quais a TLBI foi usado com sucesso.

\begin{tabular}{|l|l|}
\hline \multicolumn{1}{|c|}{ Enfermidade ou condição } & \multicolumn{1}{c|}{ Referência } \\
\hline $\begin{array}{l}\text { prevenção de complicações pós- } \\
\text { cirúrgica de mielomeningocele em } \\
\text { neonato }\end{array}$ & PINTO et al., 2008 \\
\hline $\begin{array}{l}\text { processo cicatricial exacerbado em } \\
\text { estenose traqueal severa - ação } \\
\text { bioinibitória }\end{array}$ & MAGACHO, 2005 \\
\hline asma brônquica & $\begin{array}{l}\text { AIMBIRE, 2005; LANDYSCHEV et al., } \\
\text { 2002 }\end{array}$ \\
\hline $\begin{array}{l}\text { prevenção de complicações pós- } \\
\text { cirurgias cardíacas e pulmonares }\end{array}$ & CHAVANTES \& TOMIMURA, 2004 \\
\hline $\begin{array}{l}\text { prevenção de deiscência pós- } \\
\text { revascularização do miocárdio }\end{array}$ & BAPTISTA et al., 2003 \\
\hline $\begin{array}{l}\text { tratamento de linfedema pós- } \\
\text { mastectomia }\end{array}$ & CARATI et al., 2003 \\
\hline \begin{tabular}{l} 
lombalgia crônica \\
\hline doenças articulares crônicas
\end{tabular} & GUR et al. 2003 \\
\hline $\begin{array}{l}\text { doença vascular obstrutiva arterial por } \\
\text { aterosclerose de membros inferiores }\end{array}$ & KLIMENKO et al., 2002 \\
\hline $\begin{array}{l}\text { úlceras diabéticas, neurites de várias } \\
\text { etiologias, cicatrizes hipertróficas, } \\
\text { queloides }\end{array}$ & BOWES et al., 2002 \\
\hline regeneração óssea em animais & $\begin{array}{l}\text { DORTBUDAK, 2002; TRELLES, 1987; } \\
\text { OZAWA, 1995; SAITO et al., 1997; } \\
\text { GUZZARDELLA, 2001 }\end{array}$ \\
\hline $\begin{array}{l}\text { hipertensão arterial complicada por } \\
\text { doença isquêmica do coração }\end{array}$ & SHULAKOVA et al., 2001 \\
\hline $\begin{array}{l}\text { osteoartrite e artrite reumatoide } \\
\text { úlceras cutâneas }\end{array}$ & $\begin{array}{l}\text { BROSSEAU et al., 2000; BASFORD, } \\
\text { 1989 }\end{array}$ \\
\hline $\begin{array}{l}\text { pós-operatório das cirurgias plásticas } \\
\text { e reparadoras (redução da dor e de } \\
\text { melhora da circulação local); } \\
\text { possibilidade para doenças } \\
\text { imunológicas e alérgicas }\end{array}$ & $\begin{array}{l}\text { OHSHIRO \& CALDERHEAD, 1993; } \\
\text { tonsilite crônica }\end{array}$ \\
\hline úlceras venosas & $\begin{array}{l}\text { PETREK, 1991 } \\
\text { SUGRUE et al., 1990; MESTER \& }\end{array}$ \\
\hline herpes simplex & BASFORD, 1989 \\
\hline & \\
\hline
\end{tabular}




\section{Materiais e Métodos:}

\subsection{Materiais:}

Existem vários materiais que podem ser úteis como matrizes na produção de simuladores ópticos. Para escolher qual será, de fato, utilizado é preciso levar em conta a finalidade do mesmo. É importante analisar a estabilidade química, o estado físico, a compatibilidade biológica, ajustabilidade dos parâmetros de absorção e espalhamento entre outros. Tais características dos materiais ensaiados nesse trabalho estão listadas na tabela 2.1.

Tabela 2.1 Matrizes dos simuladores ópticos.

\begin{tabular}{|c|c|c|c|c|c|c|c|}
\hline Matriz & $\begin{array}{c}\text { Durabi } \\
\text { lidade }\end{array}$ & $\begin{array}{c}\text { Estado } \\
\text { Físico } \\
\left(\mathrm{T}_{\text {amb }}\right)\end{array}$ & $\begin{array}{c}\text { Biocom- } \\
\text { patibilidade }\end{array}$ & $\begin{array}{c}\text { Inclusões } \\
\text { são } \\
\text { possíveis? }\end{array}$ & $\begin{array}{c}\text { Absorção } \\
\text { Ajustável? }\end{array}$ & $\begin{array}{c}\text { Espalha- } \\
\text { mento } \\
\text { Ajustável? }\end{array}$ & $\mathrm{n}$ \\
\hline Água & Dias & $\mathrm{L}$ & Sim & Sim & Sim & Sim & 1,35 \\
\hline Resinas & Anos & S & Não & Sim & Sim & Sim & 1,54 \\
\hline Parafina & Anos & S & Não & Sim & Sim & Sim & 1,42 \\
\hline
\end{tabular}

As resinas ensaiadas (epóxi e poliéster) foram escolhidas inicialmente por sua transparência, pois o objetivo dos experimentos com simuladores feitos a partir dessa matriz era analisar como a alteração na concentração de espalhadores altera as fluências transmitida e espalhada do simulador. Já a parafina foi ensaiada por ser um alcano com cadeia longa (20 - 40 carbonos) e essas moléculas por si só difundirem bastante a luz que interage com elas. Água funciona muito bem como matriz para moléculas biológicas, tais como melanina e colágeno, por isso sua importância nesse trabalho. Para melhor simular os vários tecidos biológicos é necessária a utilização de diversos materiais cujas características se complementam. 


\subsection{Características dos lasers, câmeras e equipamentos de medida:}

Foram usados três tipos de laser nesse trabalho. As principais características que devem ser levadas em conta são o comprimento de onda, e o diâmetro do feixe (tabela 2.2).

Tabela 2.2: Características dos Lasers.

\begin{tabular}{|c|c|c|c|c|}
\hline Tipo de Laser & $\lambda(\mathrm{nm})$ & $\begin{array}{c}\text { Potência } \\
(\mathrm{mW})\end{array}$ & Perfil do feixe & $\begin{array}{c}\text { Diâmetro }^{\text {a }} \\
(\mathrm{mm})\end{array}$ \\
\hline HeNe & 632,8 & 7,3 & $\begin{array}{c}\text { Gaussiano } \sigma= \\
0,5 \mathrm{~mm}\end{array}$ & 2,0 \\
\hline $\begin{array}{c}\text { Diodo } \\
\text { vermelho }\end{array}$ & 635 & 17,5 & Constante & 1,2 \\
\hline $\begin{array}{c}\text { Diodo } \\
\text { infravermelho }\end{array}$ & 820 & $6,4-17,7$ & $\begin{array}{c}\text { Gaussiano eliptico } \\
\sigma_{1}=3 \mathrm{~mm}, \sigma_{2}=4 \mathrm{~mm}\end{array}$ & 1,2 \\
\hline
\end{tabular}

a. É usado um obturador circular para garantir o diâmetro.

As câmeras utilizadas nos experimentos desse trabalho são do tipo CCD com lentes acopladas de tal forma que o foco da imagem seja sempre na superfície da amostra e possuem associadas a elas programas de captura e análise de imagens. A imagem é dada em níveis de cinza (nc) que variam de zero (nenhum fóton detectado em um dado pixel) a 255, detecção máxima da câmera e valor dado a todas as intensidades acima desta. A intensidade do feixe deve ser controlada de tal forma que esse limite de detecção não seja atingido. No outro extremo, a intensidade da medida não pode ser muito baixa, pois poderá ser confundida com a flutuação estatística dos valores ou com a intensidade de fundo detectada. Para evitar esses limites é necessária a utilização de filtros ópticos com diferentes percentuais de transmissão. Esses filtros fazem com que a intensidade que atinge a amostra não seja a mesma em todos os casos, sendo necessário normalizar a intensidade medida na câmera pela intensidade incidente na amostra. A intensidade luminosa 
incidente na amostra, depois de ultrapassar os filtros é medida por um power meter rever formatação (Newport Power Meter da marca Ophir, modelo 1918C). O medidor, para esses experimentos, foi operado no modo contínuo onde eram feitas 10.000 medidas a cada segundo. As médias e os desvios-padrão dessas medidas foram utilizados. O aparelho apresentou boa precisão, pois, nessas medidas, o desvio-padrão relativo ficou por volta de $4 \times 10^{-3}$. A versatilidade desse aparelho deve ser ressaltada, pois ele é capaz de medir potências de $10^{-9}$ até $10^{4} \mathrm{~mW}$. A intensidade luminosa de fundo do laboratório é de $10^{-6} \mathrm{~mW}$ e a potência nominal máxima entre todos os laser é de $50 \mathrm{~mW}$, ou seja, o power meter trabalha perfeitamente em toda a faixa das medidas realizadas.

\subsection{Amostras:}

\subsubsection{Resinas:}

As amostras têm o formato de um cilindro de $2,0 \mathrm{~cm}$ de raio $0,9 \mathrm{~cm}$ de altura cortado por um plano paralelo ao eixo do cilindro a uma distância de $1,8 \mathrm{~cm}$ desse eixo (figuras $2.1 \mathrm{a}, \mathrm{b}$ ). Esse formato é interessante, pois possibilita a análise da luz espalhada a $90^{\circ}$, em uma geometria cilíndrica, sem a deformação que seria causada pela parede curva do cilindro sem o corte. 


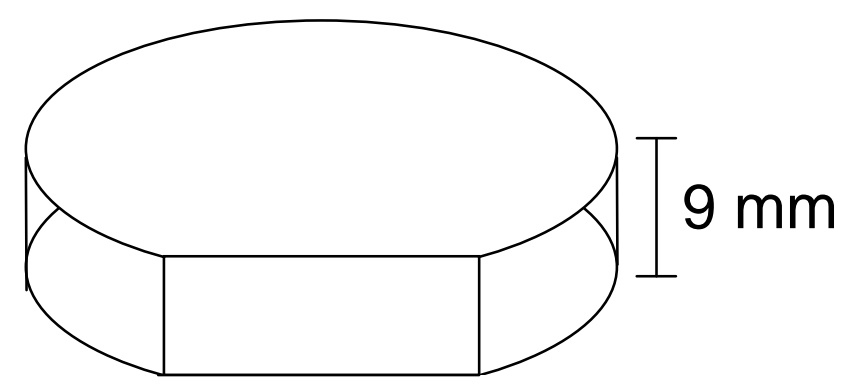

a)

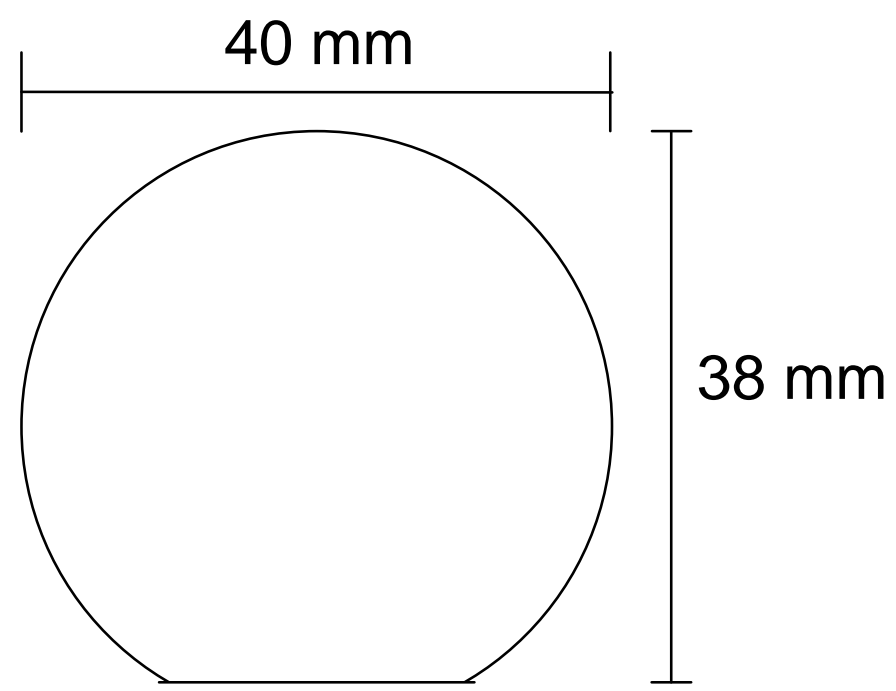

b)

Figura 2.1: Formato das amostras, a) vista frontal, b) vista superior

Para espalhar a luz foram ensaiados vários tipos de partículas, onde o ponto mais relevante eram os tamanhos e as capacidades de espalhar muito e absorver pouca luz, pois o objetivo era separar as causas de espalhamento e absorção com a finalidade de melhor compreendê-los. Deste modo, os materiais escolhidos foram as nano partículas de óxido de alumínio $\mathrm{Al}_{2} \mathrm{O}_{3}$ nas fases alfa e gama e as microesferas (ME) de vidro. Especificações relevantes sobre essas partículas são dadas na Tabela 2.3. 
Tabela 2.3: Propriedades das partículas espalhadoras.

\begin{tabular}{|c|c|c|c|c|}
\hline $\begin{array}{c}\text { Partícula } \\
\text { espalhadora }\end{array}$ & $\begin{array}{c}\text { Tamanho } \\
(\mathrm{nm})\end{array}$ & Morfologia & $\begin{array}{c}\text { Estimativa do número de } \\
\text { partículas em 1g de } \\
\text { material }\end{array}$ & $\mathrm{n}$ \\
\hline $\mathrm{Al}_{2} \mathrm{O}_{3}$ alfa & $80-100$ & Esférica & $\sim 10^{15}$ & $2,4-2,9$ \\
\hline $\mathrm{Al}_{2} \mathrm{O}_{3}$ gama & $20-60$ & Indefinida & $\sim 10^{16}$ & $2,4-2,9$ \\
\hline $\mathrm{ME}$ de vidro & 50.000 & Esférica & $\sim 10^{7}$ & 1,5 \\
\hline
\end{tabular}

Informações cedidas pelo fornecedor dos materiais, Nanum Nanotecnologia S/A

As amostras foram confeccionadas em diferentes concentrações de centros espalhadores para cada tipo de partícula (Tabela 2.4).

Tabela 2.4: Amostras de resina.

\begin{tabular}{|c|c|c|}
\hline MATRIZ & PARTICULA & CONCENTRAÇÃO $^{\mathrm{a}}(\%)$ \\
\hline \multirow{3}{*}{ Epóxi } & - & 0 \\
\cline { 2 - 3 } & $\mathrm{Al}_{2} \mathrm{O}_{3}$ alfa & $1,4,7,10,15$ \\
\cline { 2 - 3 } & $\mathrm{Al}_{2} \mathrm{O}_{3}$ gama & $1,5,6,9,10,12,15$ \\
\hline \multirow{3}{*}{ Poliéster } & - & 0 \\
\cline { 2 - 3 } & $\mathrm{Al}_{2} \mathrm{O}_{3}$ alfa & $10,20,30$ \\
\cline { 2 - 3 } & $\mathrm{Al}_{2} \mathrm{O}_{3}$ gama & $10,20,30$ \\
\cline { 2 - 3 } & $\mathrm{MEV}$ & $7,10,15,20,25,30,35,40,45,50$ \\
\hline
\end{tabular}

a: todas as concentrações são dadas pela massa de partículas sobre a massa de toda a peça.

\subsubsection{Parafina}

As amostras de parafina têm o formato apresentado na figura 2.1, mas espessuras entre 2 e $11 \mathrm{~mm}$.

\subsubsection{Melanina diluída em água:}

As diferentes tonalidades de pele representam um desafio para a dosimetria de tratamentos de LBI, pois técnicas comprovadamente eficazes para um determinado fenótipo podem ser ineficientes em tratamentos de outros grupos fenotípicos. Grande parte dessa mudança de características se deve a quantidade de melanina presente na pele dos indivíduos. Para uma boa 
simulação das características de peles de diferentes grupos étnicos se faz necessário a utilização de diferentes concentrações de absorvedores no simulador. No presente trabalho foi utilizado um composto artificial que simula as características de absorção da melanina, como pode ser visto na figura 2.2.

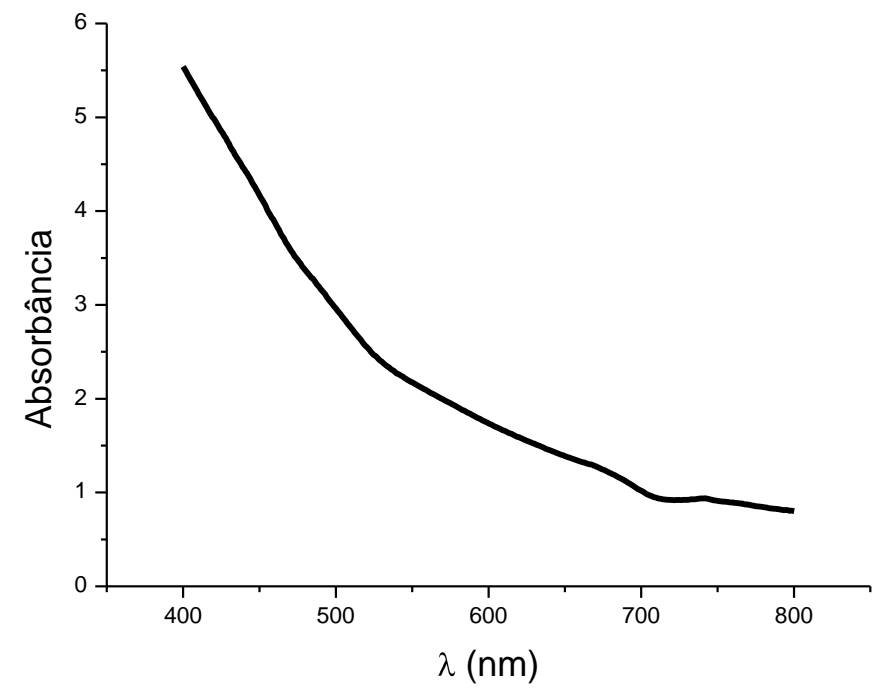

Figura 2.2: Absorbância da melanina artificial. Medida realizada no Laboratório de Biofísica do instituto de física da USP com espectrofotômetro Varian, modelo Cary50Bio UV - Visível.

\subsubsection{Procedimentos de manufatura das amostras:}

As amostras de resinas epóxi e poliéster serão consideradas iguais nesse trabalho, pois não foram verificadas diferenças óticas entre elas. Os polímeros que compõem as amostras são obtidos da reação da resina propriamente dita na fase líquida e do endurecedor MEK (butanona). A cura inicia-se por volta de 30 minutos após a mistura do endurecedor com a resina e estará completa após aproximadamente 24 horas. $\mathrm{O} \mathrm{Al}_{2} \mathrm{O}_{3}$ nano particulado em pó foi misturado à resina na fase líquida só então o endurecedor MEK foi adicionado para a solidificação da amostra. Monômero de estireno foi acrescentado, na proporção, em massa, de 1 para 10, à resina de poliéster 
aumentando a fluidez da resina quando líquida. A concentração de espalhadores é dada pela razão entre a massa de espalhadores e a massa total da amostra. A balança utilizada nessas medições tem uma precisão de $0,1 \mathrm{~g}$, as medidas envolviam massas de no mínimo $4 \mathrm{~g}$, a imprecisão nas medidas das concentrações é pequena e diminui com o aumento da concentração. A homogeneidade da amostra, isso é, a igualdade da densidade de partículas em toda a amostra foi conseguida para as amostras com $\mathrm{Al}_{2} \mathrm{O}_{3}$ nano particulado. Para as microesferas de vidro esse objetivo não foi perfeitamente alcançado, pois é possível verificar um precipitado de micro esferas.

Para a amostra obter o formato desejado a resina ainda líquida era colocada em forma de silicone com uma cavidade no formato indicado na figura 2.1. Para evitar as bolhas é necessário esperar aproximadamente 30 minutos depois de misturar os componentes e antes de adicionar o secante e colocar a mistura na forma. Após a solidificação as amostras foram lixadas e polidas para melhorar a transparência e uniformidade da superfície.

As amostras de parafina foram obtidas a partir de parafina sólida colocada em diferentes quantidades dentro das formas de silicone e foram levadas ao forno a $85^{\circ} \mathrm{C}$, temperatura em que ocorre a fusão da parafina. Quando retirada do forno ela está no formato correto e a espessura pode ser facilmente corrigida lixando a amostra para retirar o excesso.

A melanina diluída em água em concentrações entre 0 e $125 \mu \mathrm{g} / \mathrm{mL}$ foi colocada dentro de uma cubeta feita de acrílico, transparente aos comprimentos de onda usados na iluminação. A água foi considerada transparente, pois também apresenta coeficiente de absorção muito baixo para 
essa faixa do espectro, $\mu_{\mathrm{a}} \approx 10^{-3} \mathrm{~cm}^{-1}$. Portanto, toda a absorção é devida à melanina artificial.

\subsubsection{Tecido suíno:}

Devido a sua semelhança com tecidos humanos os tecidos suínos vêm sendo largamente utilizados para fins experimentais. Nesse trabalho analisamos pele, tecido adiposo e músculo de suíno recém-abatido, conservado a baixa temperatura $\left(<10^{\circ} \mathrm{C}\right)$, mas não congelado. As amostras são de um mesmo animal, mas apresentam diferentes espessuras de pele, tecido adiposo e músculo. Primeiramente elas foram analisadas juntas e, em seguida, cortes foram feitos para tentar isolar camadas de pele, tecido adiposo e músculo, com a finalidade de conhecer melhor as características de espalhamento e absorção desses três tipos de tecido bem como o que acontece na interface entre eles. A soma das espessuras das partes separadas é ligeiramente diferente da espessura da amostra com os tecidos ainda juntos, como pode ser verificado na tabela 2.5. Isso se deve a perda de material e a deformação da amostra devido ao corte. Na tabela 2.5 a numeração se refere a cada uma das cinco amostras; e as letras i, p, g, m denominam a amostra inteira, pele, tecido adiposo e músculo, respectivamente. 
Tabela 2.5: Amostras de tecido suíno.

\begin{tabular}{|c|c|c|}
\hline Amostra & Componentes e espessuras $(\mathrm{mm}), \sigma=0,5 \mathrm{~mm}$ & $\begin{array}{c}\text { Fator de } \\
\text { Atenuação }^{a} \\
\left(\times 10^{-3}\right)\end{array}$ \\
\hline $\mathrm{i1}$ & Pele 3,5; Tecido adiposo 3,5; Músculo 9,5 & $0,8(2)$ \\
\hline $\mathrm{p} 1$ & Pele 1,3 & $55(18)$ \\
\hline$g 1$ & Tecido adiposo com músculo 7,0 & $4,8(1)$ \\
\hline m1 & Músculo 7,0 & $12,6(4)$ \\
\hline $\mathrm{i} 2$ & Pele 2,7; Tecido adiposo 7,7; Músculo 2,5 & $1,5(1)$ \\
\hline p2 & Pele 1,5 & $128(21)$ \\
\hline$g 2$ & Tecido adiposo 6,5 & $3,0(3)$ \\
\hline $\mathrm{m} 2$ & Músculo 4,0 & $16,7(1)$ \\
\hline i3 & Pele 2,3; Tecido adiposo 4,5; Músculo 7,9 & $1,6(3)$ \\
\hline p3 & Pele 1,6 & $227(63)$ \\
\hline g3 & Tecido adiposo 6,0 & $4,00(5)$ \\
\hline m3 & Músculo 7,0 & $12,4(1)$ \\
\hline $\mathrm{i} 4$ & Pele 2,2; Tecido adiposo 5,7; Músculo 5,0 & $3,9(4)$ \\
\hline $\mathrm{p} 4$ & Pele 2,1 & $26,7(5)$ \\
\hline g4 & Tecido adiposo 5,5 & $7,3(11)$ \\
\hline m4 & Músculo 5,0 & $14,3(10)$ \\
\hline i5 & Pele 1,7; Tecido adiposo 6,8; Músculo 6,5 & $1,00(5)$ \\
\hline p5 & Pele 1,6 & $32,7(31)$ \\
\hline g5 & Tecido adiposo 9,0 & $4,1(1)$ \\
\hline m5 & Músculo 6,0 & $16,1(25)$ \\
\hline
\end{tabular}

\subsection{Método e experimentos:}

O método consiste na iluminação da amostra com um laser e a detecção da luz transmitida ou espalhada a $90^{\circ}$ com câmera CCD. O feixe atravessa um filtro atenuador e é espalhado e absorvido pela amostra. A luz transmitida é capturada pela CCD na posição 1 e a luz espalhada a $90^{\circ}$ é capturada pela CCD na posição 2 (figura 2.3). 


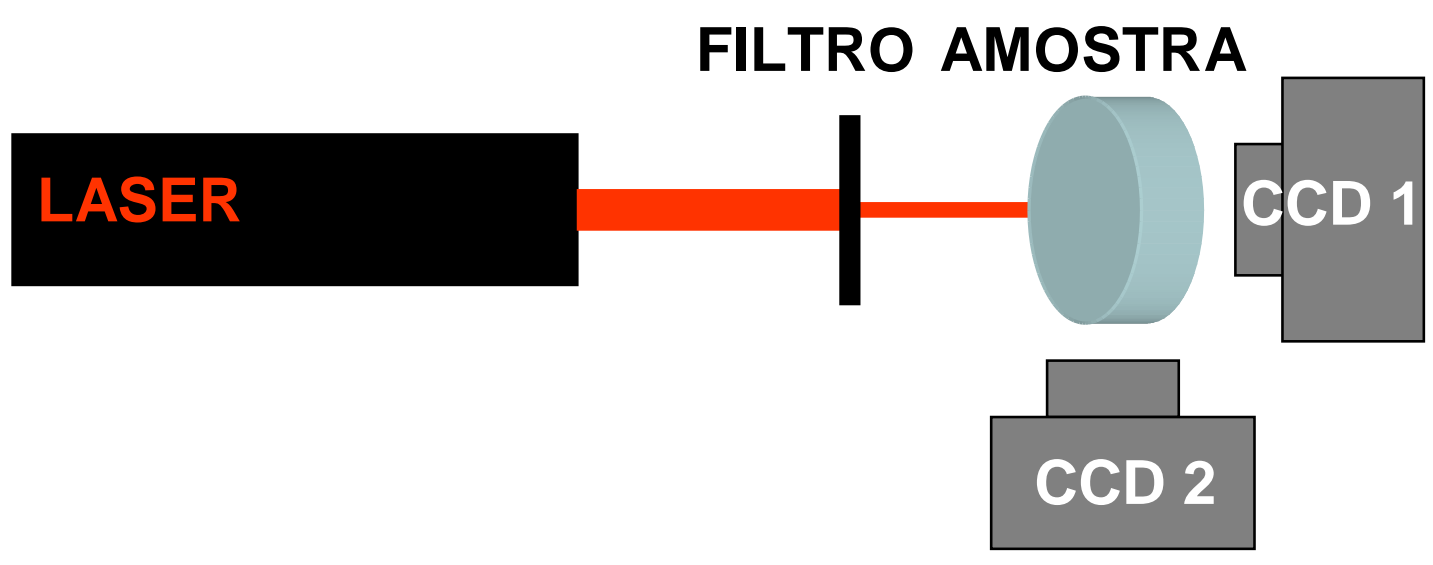

Figura 2.3: Arranjo experimental.

Diversos experimentos foram realizados utilizando esse arranjo. Com as amostras de resina, foram feitos experimentos em que observamos a variação das características da transmissão e do espalhamento conforme a concentração e o tipo de espalhador são alterados. Já com a parafina analisamos essas mudanças devido à variação da espessura e coloração da amostra. Na água o aumento da concentração da melanina leva a diminuição da transmitância da amostra. Os experimentos estão sumarizados na tabela 2.6.

Tabela 2.6: experimentos.

\begin{tabular}{|c|c|c|}
\hline Experimento & Amostra & Parâmetros Variados \\
\hline \multirow{4}{*}{ Transmissão } & Resina & $\begin{array}{l}\lambda, \text { concentração e tipo do } \\
\text { espalhador. }\end{array}$ \\
\hline & Parafina & $\lambda$, espessura \\
\hline & Água & $\lambda$, concentração do corante \\
\hline & Suíno & Tipo de tecido e espessura \\
\hline \multirow{3}{*}{ Espalhamento } & Resina & $\begin{array}{l}\lambda \text {, concentração, tipo do } \\
\text { espalhador e posição de } \\
\text { incidência. }\end{array}$ \\
\hline & Parafina & $\lambda$, posição de incidência \\
\hline & Suíno & Tipo de tecido e espessura \\
\hline
\end{tabular}




\subsection{Análise de dados:}

As imagens obtidas foram analisadas com o software ImageJ 1.41 que fornece os níveis de cinza em cada pixel da imagem. Os valores na escala de cinza são linearmente correlacionados a intensidade luminosa (figura 2.4). Assim é possível estimar a distribuição espacial da luz que sai da amostra.

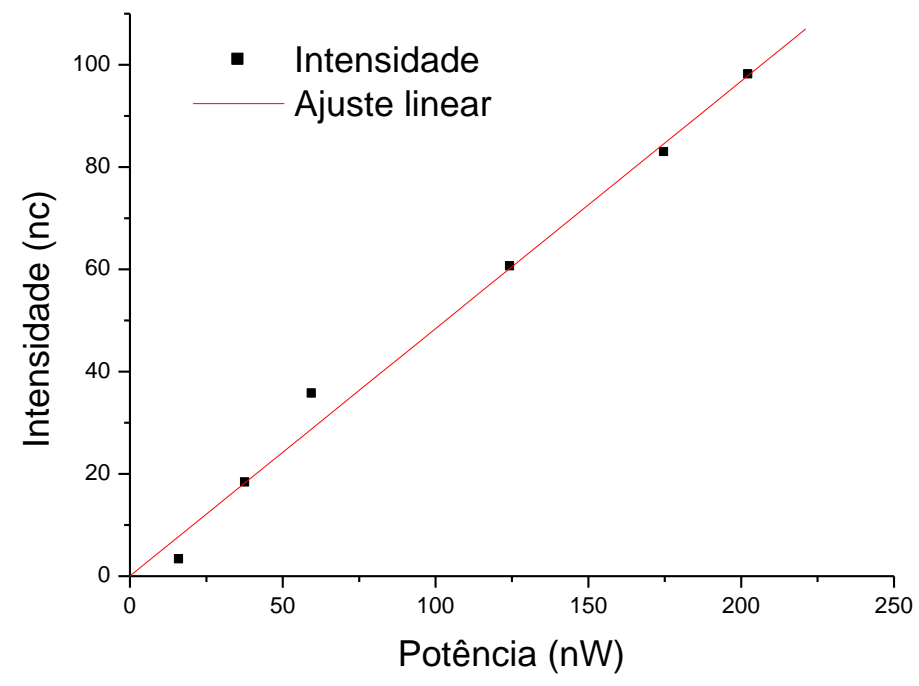

Figura 2.4: Intensidade de luz por potência do feixe.

A análise de parâmetros dos perfis de intensidade nos permite caracterizar e comparar as diversas amostras. O perfil da luz transmitida (figura 2.5) poderia ser ajustado, na maioria dos casos, por uma distribuição gaussiana (figura 2.6) (Ramos et $A L, 2010$ ). No entanto, isso nem sempre foi possível, e para manter a metodologia de análise optamos por obter os valores de $I_{M}$, da largura a meia altura $(w)$ e de área, diretamente das curvas experimentais, e não de resultados de ajustes gaussianos. 


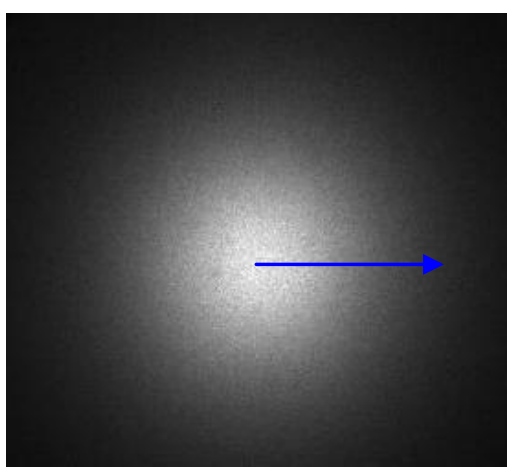

Figura 2.5: Imagem da luz transmitida através de uma amostra com $10 \% \mathrm{Al}_{2} \mathrm{O}_{3}$ alfa.

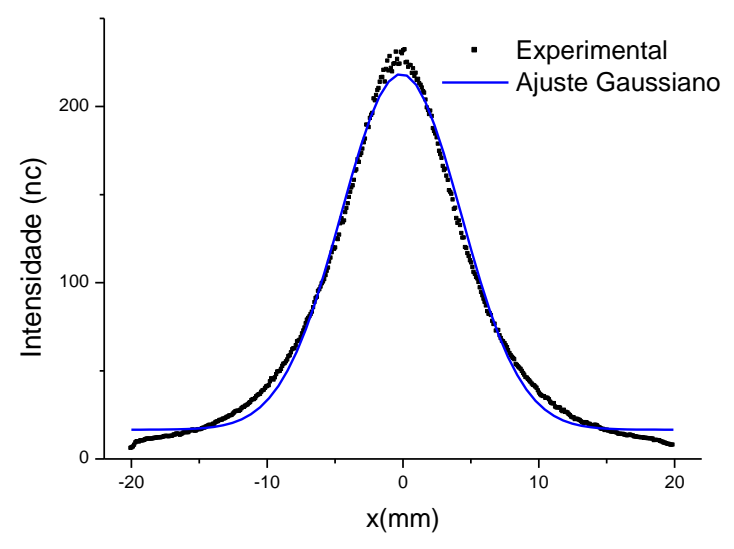

Figura 2.6: Dados experimentais e ajuste gaussiano para a amostra da figura 2.5 .

Já as imagens onde a câmera e o feixe de laser estão posicionados perpendicularmente (figura 2.7) têm perfis que mostram um crescimento rápido inicial seguido de um decréscimo assintoticamente exponencial (figura 2.8). Desse gráfico é interessante analisar a intensidade máxima e a profundidade onde ela ocorre; a largura do pico e o coeficiente de atenuação da exponencial.

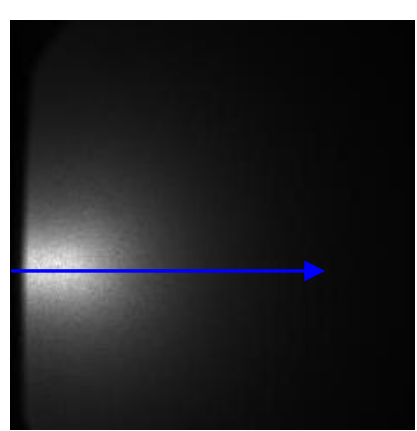

Figura 2.7: Imagem da luz espalhada a $90^{\circ}$ por amostra de resina com $7 \%$ de $\mathrm{Al}_{2} \mathrm{O}_{3}$.alfa.

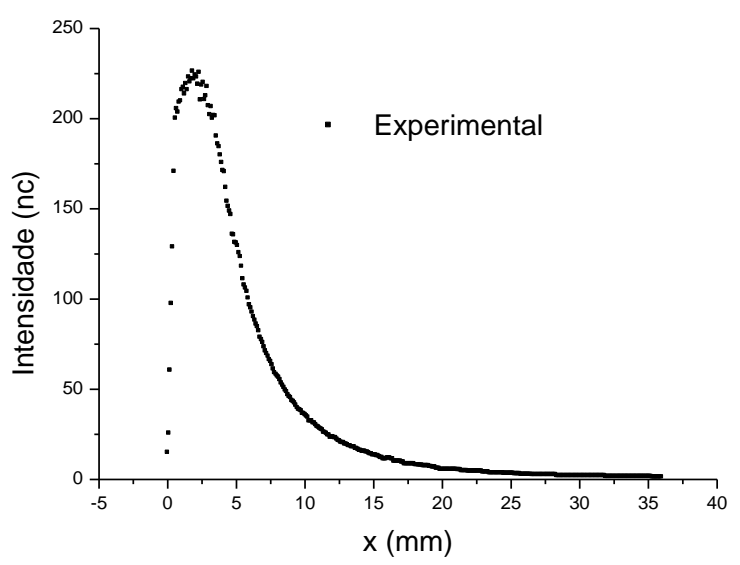

Figura 2.8: Dados experimentais da intensidade espalhada a $90^{\circ}$ da amostra da figura 2.7. 
As incertezas nas medidas foram calculadas de duas formas. $\mathrm{Na}$ primeira foram tiradas 20 fotos do mesmo sistema com todos os parâmetros fixados. Essa medida tinha como objetivo analisar a variação nas imagens devido a flutuações na intensidade do laser, no sistema de aquisição e no programa de análise. Através de subtração de uma imagem das outras, pixel por pixel, foram sempre obtidas imagens com intensidade igual a zero em todos os pontos. Portanto, podemos concluir que a aparelhagem não gera erros significativos e não contribui significativamente para a incerteza.

Outra fonte de erro se deve à não uniformidade dos simuladores confeccionados. Para avaliarmos isso fizemos vários simuladores em duplicata e comparamos as imagens dos pares. Ao fazer a subtração de imagens obtivemos valores próximos a zero em todos os pontos, as variações em cada ponto eram devidas, provavelmente, a flutuações na concentração de espalhador ou absorvedor nas amostras. Essa fonte de incerteza também pode ser desconsiderada por gerar variações insignificantes.

Fizemos 20 vezes a aquisição da imagem de luz transmitida através da amostra modificando o ponto de incidência e calculamos a média, o desvio padrão, e o desvio padrão relativo (coeficiente de variação $-\sigma_{\text {rel) }}$. Para não superestimar a incerteza na concentração devemos avaliar apenas a luz que passa pela amostra sem interagir, ou seja, apenas a região de tamanho menor que a área de abertura do feixe será levada em consideração. Esse processo foi feito para amostras de resina com quatro diferentes concentrações de $\mathrm{Al}_{2} \mathrm{O}_{3}$. As médias dos coeficientes de variação, bem como seus respectivos desviospadrão podem ser vistos na tabela 2.7 . 
Tabela 2.7: Médias e Desvios padrão relativos $\left(\sigma_{\text {rel }}\right)$.

\begin{tabular}{|c|c|c|c|}
\hline Concentração (\%) & $\begin{array}{c}\text { Intensidade } \\
\text { transmitida (nc) }\end{array}$ & Média de $\sigma_{\text {rel }}$ & Desvio-padrão de $\sigma_{\text {rel }}$ \\
\hline 7 & 83 & 0,0331 & 0,0142 \\
\hline 10 & 51 & 0,0268 & 0,0121 \\
\hline 15 & 35 & 0,0415 & 0,0179 \\
\hline 30 & 29 & 0,0252 & 0,0083 \\
\hline
\end{tabular}

Da tabela 2.7. vemos que a média de $\sigma_{\text {rel }}$ não depende da concentração e que podemos usar $\sigma_{\text {rel }}=0,032$, para todos os perfis de intensidade das amostras não biológicas. Por isso, em todo esse trabalho, o desvio padrão será sempre considerado $3,2 \%$ da intensidade medida.

A maior fonte de incerteza é a localização da amostra em relação ao feixe de laser, pois isso leva a interação com partes diferentes da amostra, com diferentes concentrações de espalhador e/ou absorvedor.

\subsection{Dedos humanos in vivo.}

As falanges mediais dos dedos indicadores de 47 voluntários foram iluminadas com laser HeNe (633 nm) e laser diodo infravermelho (820 nm). A luz transmitida através do dedo foi fotografada com a câmera CCD. A largura e a espessura dos dedos foram medidas, a cor de pele dos voluntários foi separada, subjetivamente, em três grupos, de acordo com a tonalidade. As espessuras e tonalidades desse conjunto de dedos foram utilizadas para explicar qualitativamente as intensidades transmitidas observadas nas imagens. Os dados obtidos das imagens dos dedos foram utilizados para a manufatura de simuladores de dedos com espessura, coeficiente de absorção e coeficiente de espalhamento próximo aos de dedos humanos. 


\section{RESULTADOS E DISCUSSÃO:}

Nesse capítulo serão apresentados resultados obtidos em experimentos de transmissão e espalhamento de laser ao atravessar amostras de simuladores ópticos. Melanina artificial diluída em água forma um sistema simples no qual foi possível determinar $\mu_{\mathrm{a}}$, como poderá ser visto na seção 3.1. Amostras de resina com $\mathrm{Al}_{2} \mathrm{O}_{3}$ alfa, $\mathrm{Al}_{2} \mathrm{O}_{3}$ gama e microesferas de vidro como espalhadores são estudadas nas seções 3.2, 3.3 e 3.4, respectivamente. As propriedades ópticas da parafina são discutidas na seção 3.5. Tecidos suínos, por serem opticamente semelhantes aos tecidos humanos, foram analisados e seus resultados estão apresentados na seção 3.6. Os dedos de 48 voluntários foram iluminados com laser e o padrão da luz transmitida por eles será analisado quantitativa e qualitativamente na seção 3.7. A partir dos resultados supracitados foi possível o desenvolvimento de simuladores ópticos de dedo. A confecção e análise desses simuladores, assim como as comparações com dedos humanos, serão apresentadas na seção 3.8.

\subsection{Amostras de Melanina:}

O fenótipo da pele humana é determinado principalmente pelo número, tamanho, agregação e distribuição de melanossomas que, por sua vez, são agrupamentos de melanina. Em peles escuras os melanossomas são maiores, mais pigmentados, e se distribuem uniformemente, já nas peles mais claras os melanossomas são menores, com menos melanina e formam agregados. Para levar em conta a quantidade de luz absorvida por diferentes fenótipos de pele foi realizado um experimento de transmissão por solução aquosa de um composto artificial que simula o espectro de absorção da melanina. Muitos são 
os fatores que interferem na absorção de luz na pele, mas podemos considerar que a atenuação está diretamente relacionada à concentração de melanina, bem como à espessura da pele.

Para uma concentração de $125 \mu \mathrm{g} / \mathrm{mL}$ de melanina artificial, a espessura da amostra foi variada entre 1,0 e $21,0 \mathrm{~mm}$ e a intensidade da luz transmitida diminuiu como pode ser visto na figura 3.1.

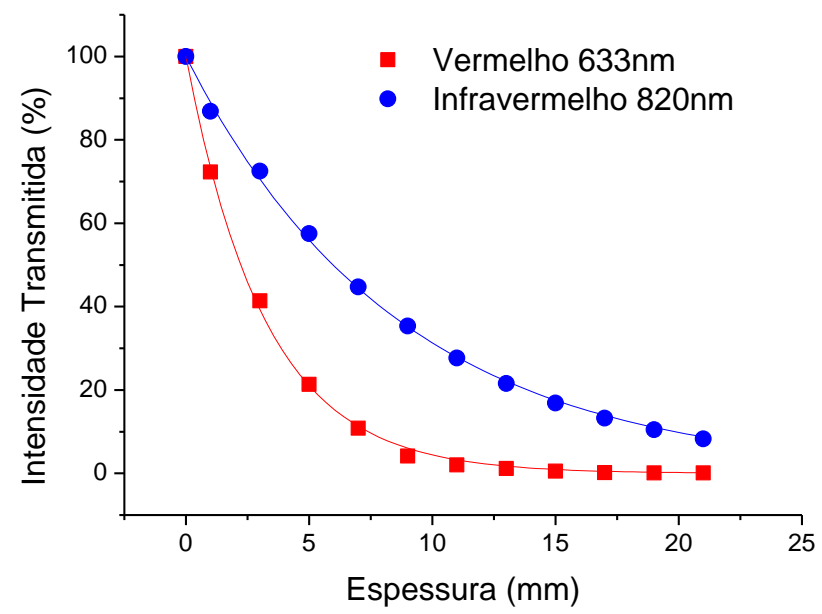

Figura 3.1: Variação da intensidade transmitida com a espessura da amostra para $\lambda=633 \mathrm{~nm}$ e $\lambda=820 \mathrm{~nm}$.

Uma curva exponencial foi ajustada aos valores obtidos experimentalmente, como é previsto pela lei de Lambert-Beer. Desse resultado foi possível obter o coeficiente de atenuação, $\mu_{t}$, para essa concentração de melanina artificial nos dois comprimentos de onda. Para $\lambda=633 \mathrm{~nm}$, $\mu_{\mathrm{t}}=3,12 \mathrm{~cm}^{-1}$ e para $\lambda=820 \mathrm{~nm}, \mu_{t}=1,16 \mathrm{~cm}^{-1}$. Isso quer dizer que em média os fótons atingem a profundidade $\left(<x>=1 / \mu_{t}\right)$ de $3,21 \mathrm{~mm}$ e $8,62 \mathrm{~mm}$ para $\lambda=633 \mathrm{~nm}$ e $\lambda=820 \mathrm{~nm}$, respectivamente. Esses valores de $\mu_{\mathrm{t}}$ corroboram a prática corrente em tratamentos com LBI de usar os comprimentos de onda no infravermelho para tratamentos em tecidos mais profundos (sob a pele). 
Apesar de o experimento ser feito com geometria de feixe largo a redução da intensidade foi exponencial, e isso é um forte indício de que a absorção é o principal processo que gera atenuação, por isso podemos dizer que $\mu_{\mathrm{t}}=\mu_{\mathrm{a}}$. $\mathrm{O}$ coeficiente de absorção é diretamente proporcional à concentração de cromóforos. Portanto, a partir dos valores obtidos acima para $\mu_{\mathrm{a}}$ sabemos os valores de $\mu_{\mathrm{a}}$ para as frações daquela concentração. A intensidade luminosa transmitida através da amostra depende da concentração de melanina artificial diluída em água. Para uma espessura de $20 \mathrm{~mm}$, a intensidade dos feixes de $633 \mathrm{~nm}$ e $820 \mathrm{~nm}$ diminui exponencialmente com o aumento da concentração, ou seja, do $\mu_{\mathrm{a}}$ (figura 3.2)
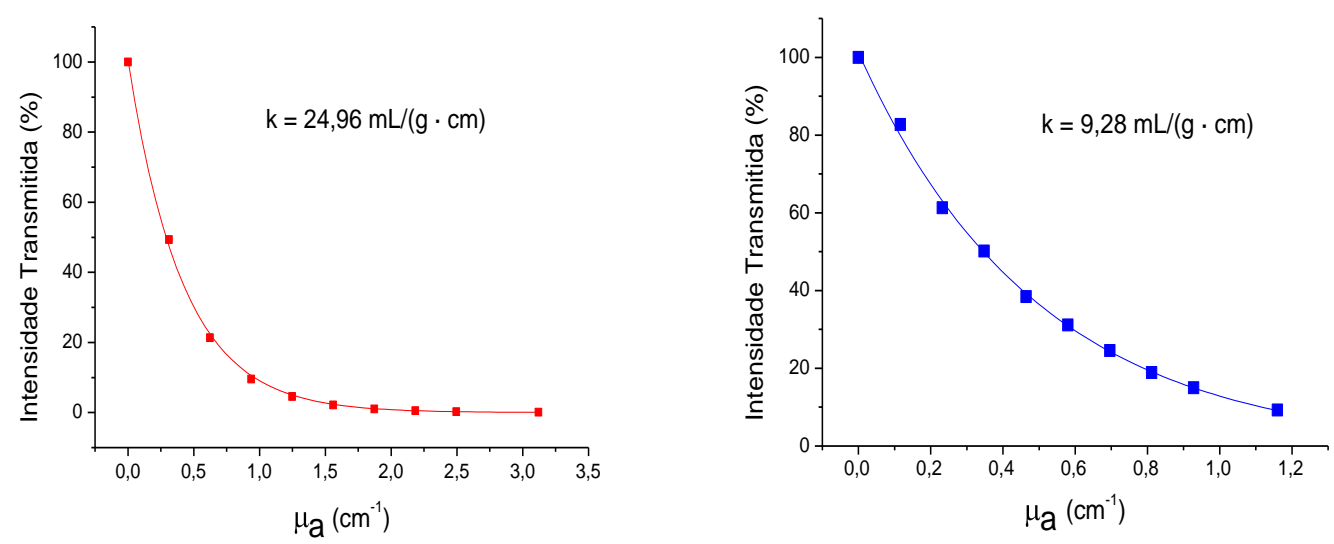

Figura 3.2: Variação da intensidade transmitida com $\mu_{a}$ para $\lambda=633 \mathrm{~nm}$ (esquerda) e $\lambda=820 \mathrm{~nm}$ (direita). Os diversos valores de $\mu_{\mathrm{a}}$ foram obtidos da expressão (1.1), usando concentrações de melanina na faixa de $12,5 \mu \mathrm{g} / \mathrm{mL}$ a $125 \mu \mathrm{g} / \mathrm{mL}$.

\subsection{Amostras de resina com $\mathrm{Al}_{2} \mathrm{O}_{3}$ alfa como espalhador:}

O espalhamento, para dosimetria de tratamentos de LBI, representa uma dificuldade para simulação ainda maior que a absorção, pois o coeficiente de espalhamento, para a maioria dos tecidos biológicos, é muito maior e varia muito mais, para cada tipo de tecido, do que o coeficiente de absorção. $O$ 
espalhamento leva à iluminação de áreas fora da direção do feixe e isso varia de acordo com as características dos centros espalhadores. A iluminação de regiões adjacentes à direção de propagação do feixe deve ser levada em consideração para tratamentos de LBI, pois essa região iluminada por fótons espalhados também estará sendo tratada.

\subsubsection{Transmissão:}

Analisamos as características apresentadas quanto à transmissão e ao espalhamento das amostras com resinas como matriz e $\mathrm{Al}_{2} \mathrm{O}_{3}$ alfa como partículas espalhadoras. No experimento de transmissão é importante observar o perfil das intensidades e características desses perfis tais como: intensidade máxima $I_{M}$, largura do pico a meia altura (w) e área sob a curva. Esses dados nos dão informações sobre as propriedades de atenuação e espalhamento dessas amostras. Para as diversas concentrações de $\mathrm{Al}_{2} \mathrm{O}_{3}$ alfa, iluminados com feixes de $\lambda=633 \mathrm{~nm}$, os perfis de transmissão variam como apresentado na Figura 3.3. 


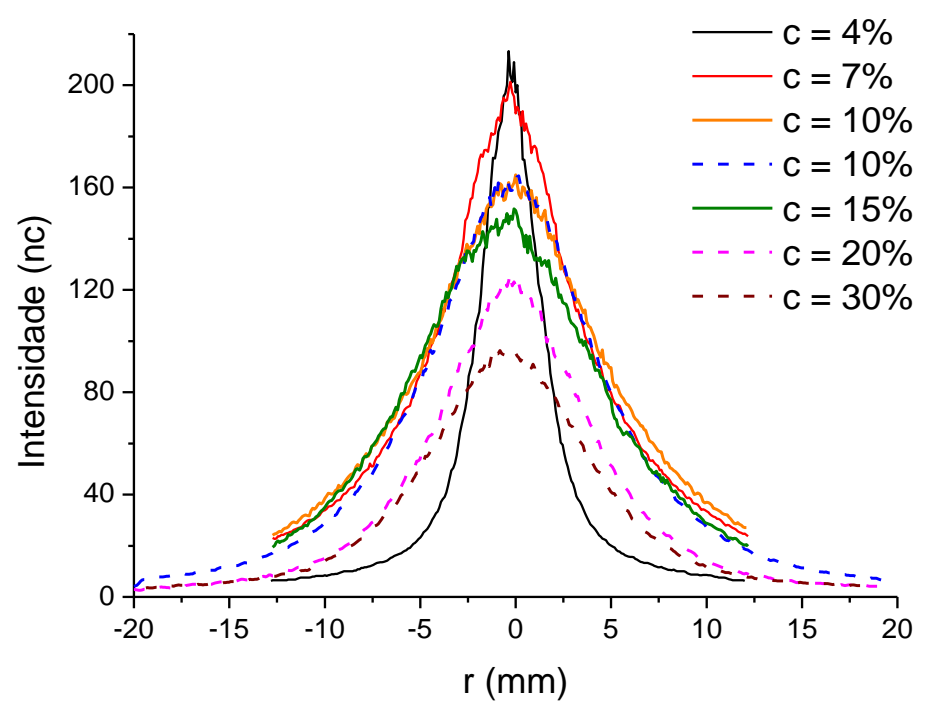

Figura 3.3: Perfis de transmissão nas amostras de $\mathrm{Al}_{2} \mathrm{O}_{3}$ alfa em resina.

As curvas em linha contínua são de amostras de resina de epóxi e as tracejadas, de poliestireno. Para a concentração 10\% há amostra das duas resinas. Para os perfis da figura 3.3 , a intensidade máxima $\left(I_{M}\right)$, a largura do pico (w) e a área sob a curva variam com a concentração de espalhador como pode ser visto na figura 3.4. Nos gráficos de $I_{M}, w$ e Área as linhas ligando pontos estão colocadas para facilitar a visualização. 

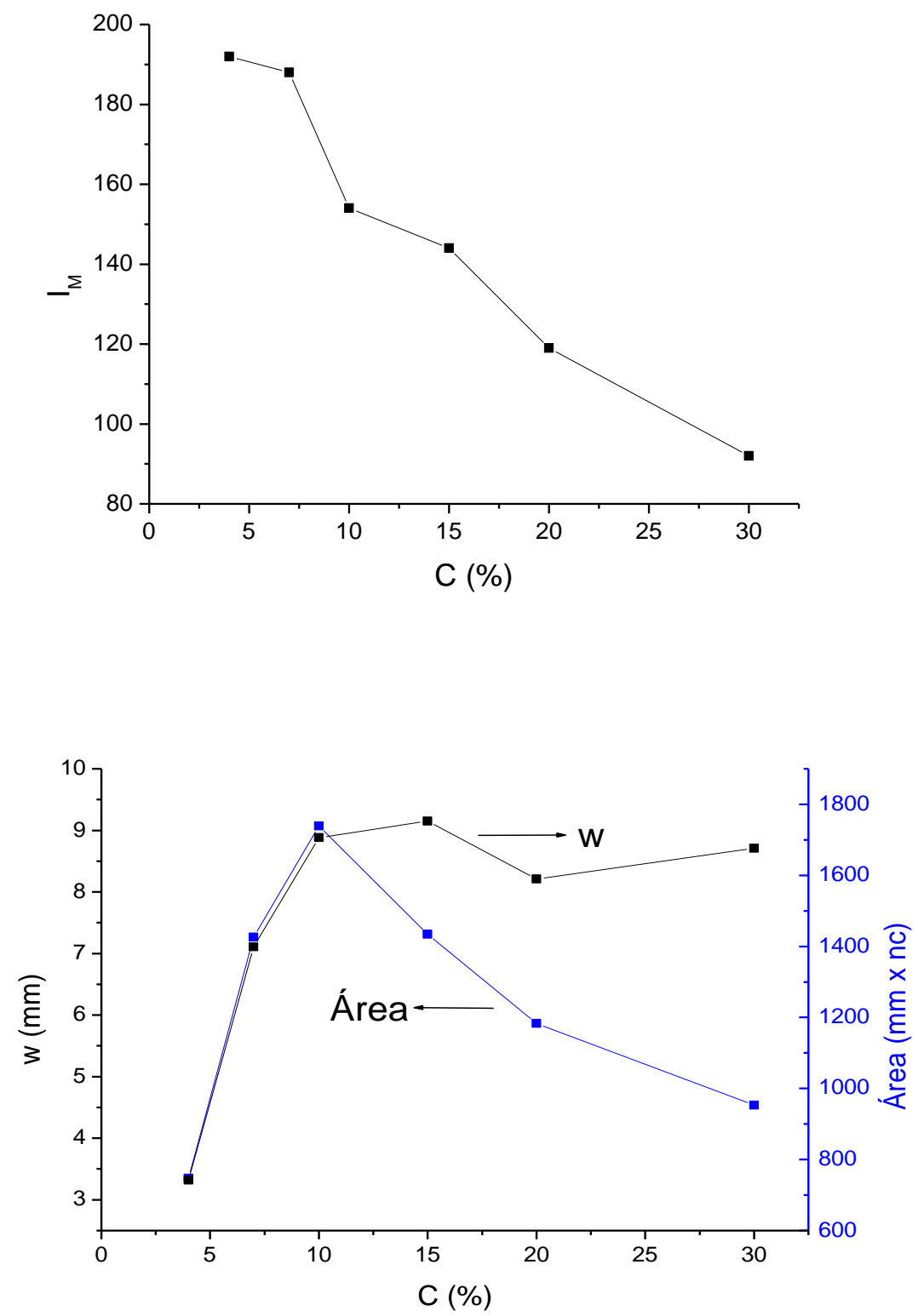

Figura 3.4: Variação de $I_{M}$ (em cima); e w e Área sob os perfis da figura 3.3 (em baixo), em função da concentração de $\mathrm{Al}_{2} \mathrm{O}_{3}$ alfa.

\subsubsection{Espalhamento a $90^{\circ}$ :}

As amostras foram fotografadas a um ângulo de $90^{\circ}$ da direção do feixe. Os perfis das amostras com $\mathrm{Al}_{2} \mathrm{O}_{3}$ alfa iluminados são mostrados na figura 3.5 e as características relevantes como intensidade máxima $\left(I_{M}\right)$, posição da intensidade máxima $\left(x\left(I_{M}\right)\right)$ são mostrados na figura 3.6. 


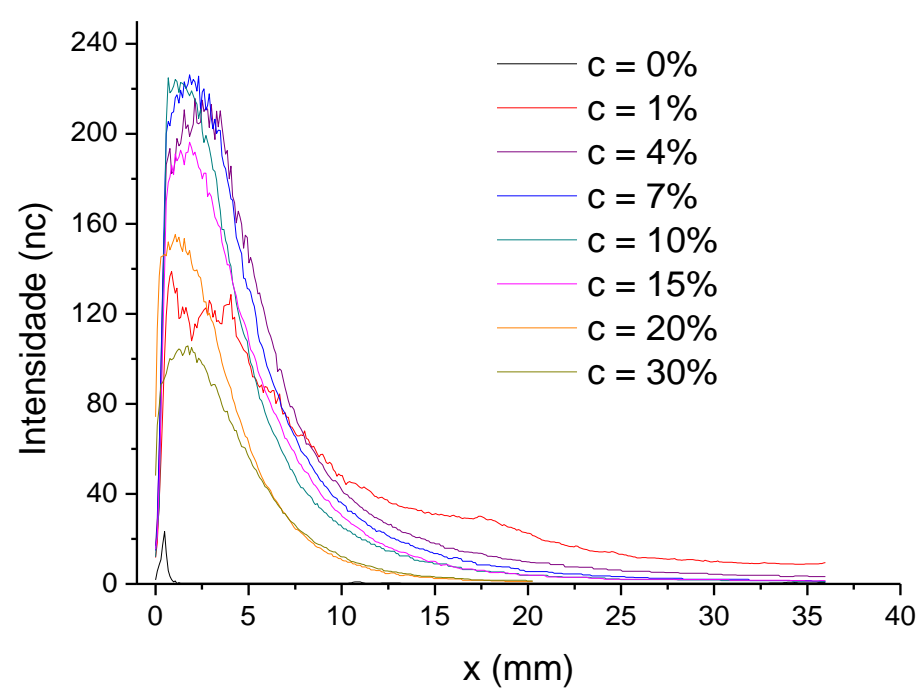

Figura 3.5: Intensidade espalhada a partir das laterais das amostras de $\mathrm{Al}_{2} \mathrm{O}_{3}$.

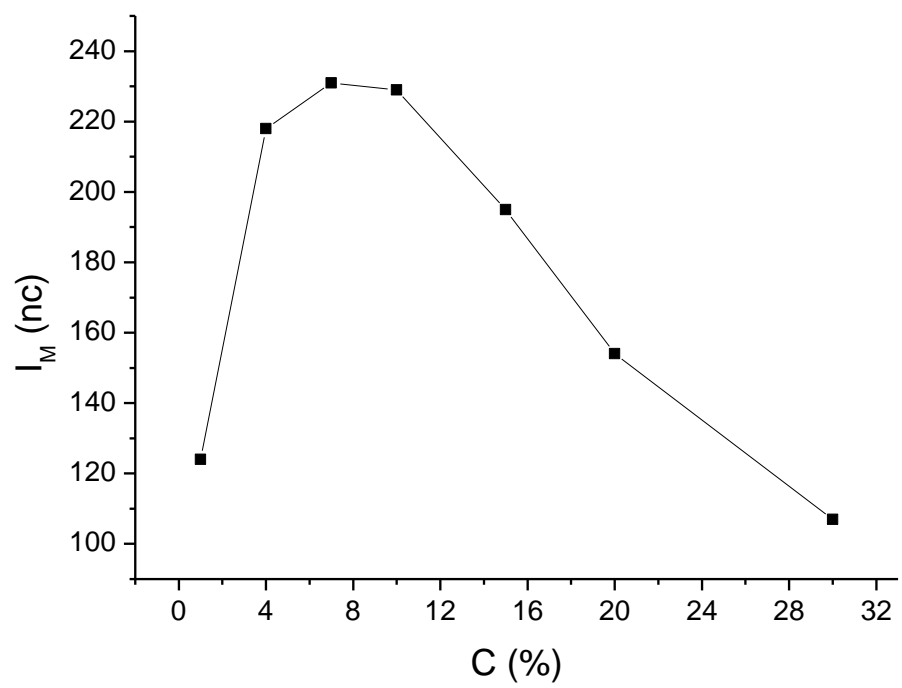

Figura 3.6: $I_{M}$ e $x\left(I_{M}\right)$ para espalhamento a $90^{\circ}$ por amostras de resina com $\mathrm{Al}_{2} \mathrm{O}_{3}$ alfa como espalhador. (continua) 


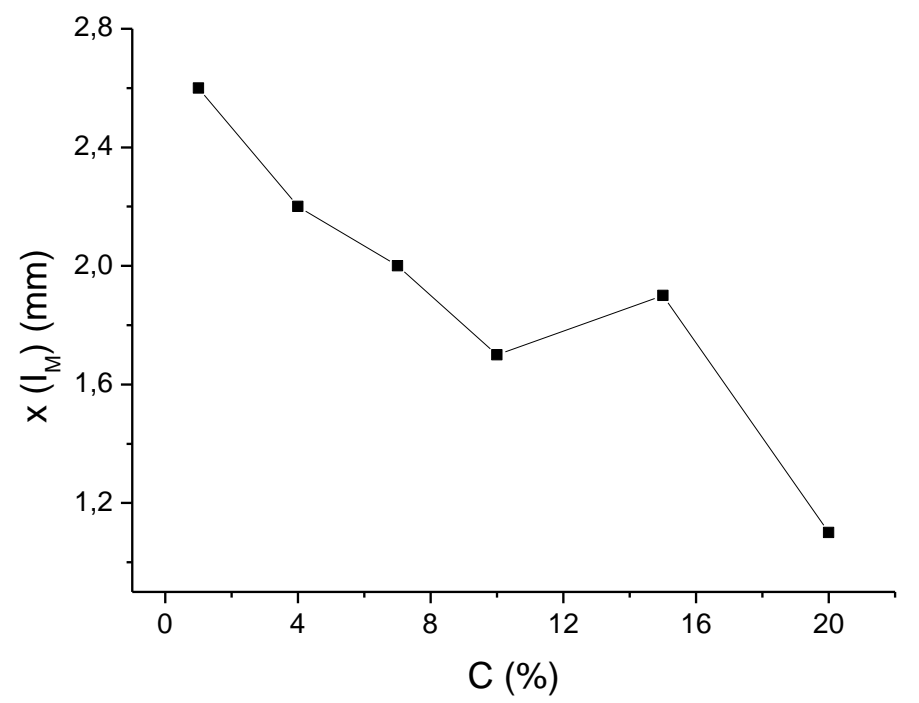

Figura 3.6: $I_{M}$ e $x\left(I_{M}\right)$ para espalhamento a $90^{\circ}$ por amostras de resina com $\mathrm{Al}_{2} \mathrm{O}_{3}$ alfa como espalhador.

\subsection{Amostras de resina com $\mathrm{Al}_{2} \mathrm{O}_{3}$ gama como espalhador:}

Embora sejam a mesma substância química, os óxidos de alumínio $\left(\mathrm{Al}_{2} \mathrm{O}_{3}\right)$ alfa e gama têm características de espalhamento diferentes. Isso é explicado pelos tamanho e forma de partículas, os quais diferem nos dois tipos de $\mathrm{Al}_{2} \mathrm{O}_{3}$.

\subsubsection{Transmissão:}

Para as diversas concentrações de $\mathrm{Al}_{2} \mathrm{O}_{3}$ gama, iluminados com feixes de $\lambda=633 \mathrm{~nm}$, os perfis de transmissão variam como apresentado na figura 3.7 e a Intensidade máxima e a largura do pico são mostradas na figura 3.8.

Estima-se que, para a mesma concentração, existam dez vezes mais partículas de $\mathrm{Al}_{2} \mathrm{O}_{3}$ gama que de $\mathrm{Al}_{2} \mathrm{O}_{3}$ alfa. Isso faz com que ocorra um maior número de interações nas amostras feitas com $\mathrm{Al}_{2} \mathrm{O}_{3}$ gama que nas de $\mathrm{Al}_{2} \mathrm{O}_{3}$ 
alfa, isso é evidenciado pela rápida diminuição de $I_{M}$ com o aumento da concentração para o espalhador tipo gama, quando se comparam as figuras 3.4 e 3.8. Entretanto, w é sempre maior nas amostras de alfa que nas de gama, fenômeno que pode ser explicado pelos diferentes formatos das partículas espalhadoras. Outra diferença em relação às amostras com o espalhador tipo alfa é que o aumento de w com a concentração ocorre para todo o intervalo, sem saturação.
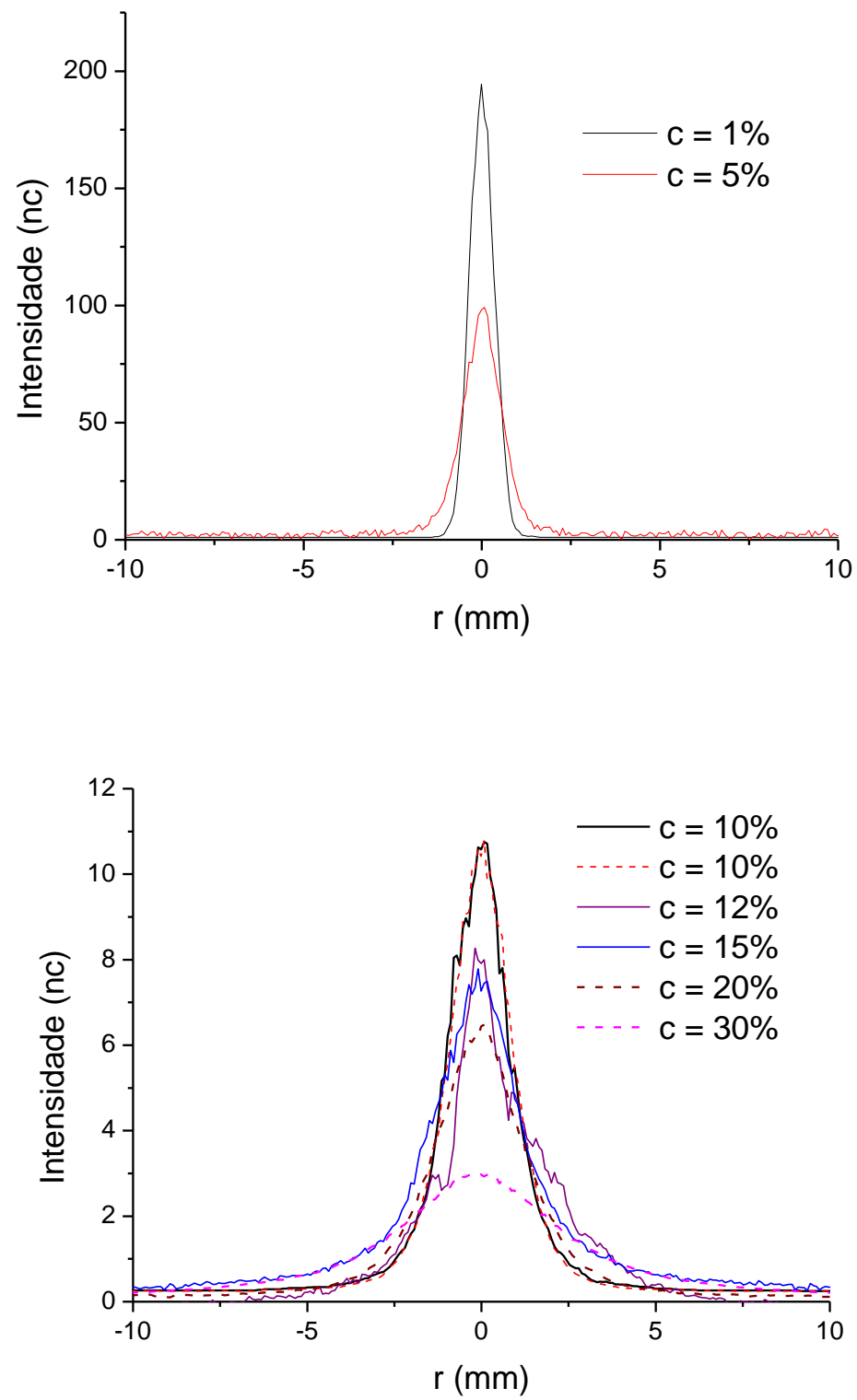

Figura 3.7: Perfis de transmissão nas amostras de $\mathrm{Al}_{2} \mathrm{O}_{3}$ alfa em resina. 

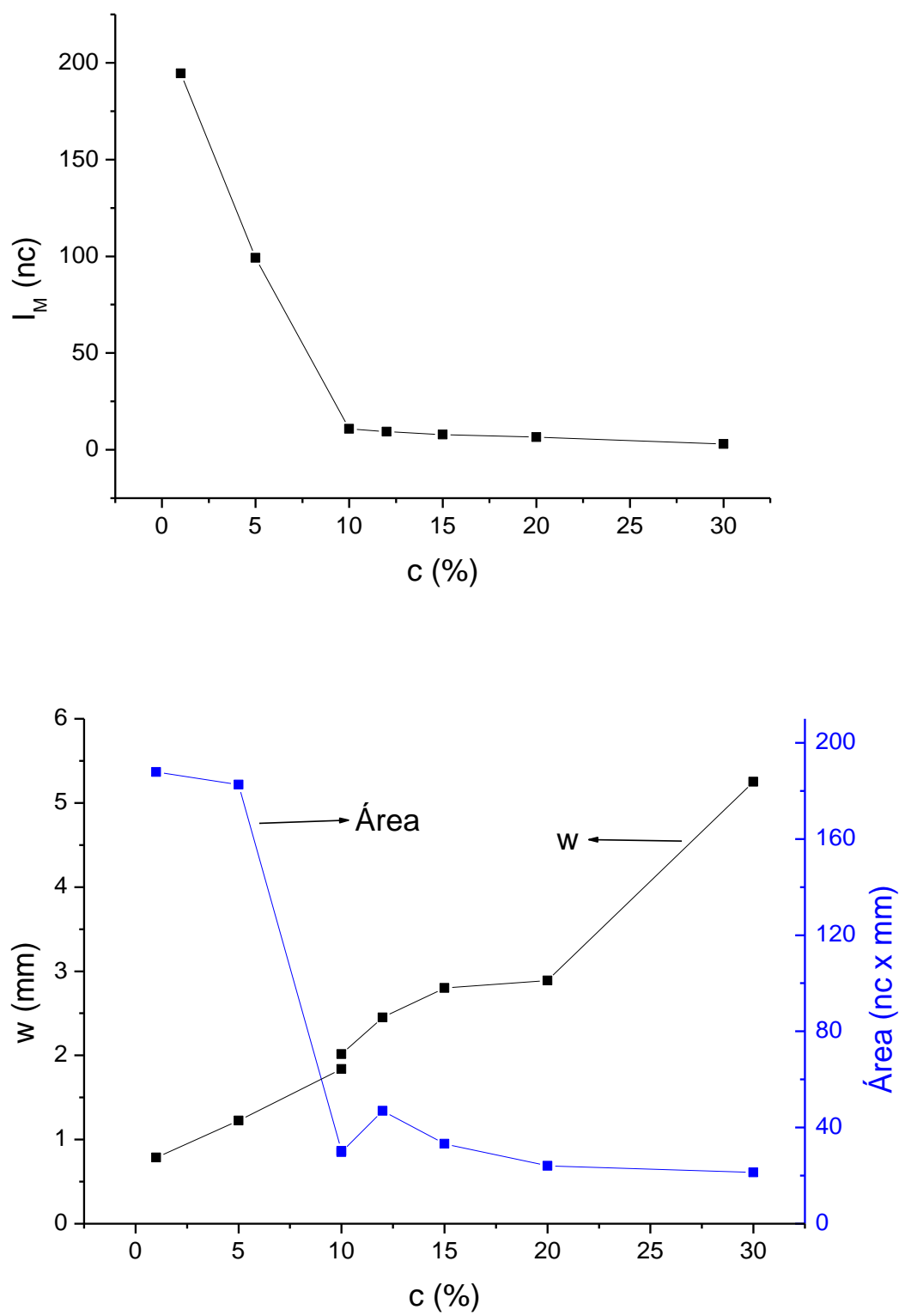

Figura 3.8: Variação de $I_{M}$ (em cima); e de w e Área sob os perfis da figura 3.3 (embaixo), em função da concentração de $\mathrm{Al}_{2} \mathrm{O}_{3}$ gama.

\subsection{Amostras de resina com microesferas de vidro:}

A direção preferencial de espalhamento depende dos tamanhos dos centros espalhadores, como é evidenciado pela teoria Mie para o espalhamento da luz. O espalhamento por centros espalhadores com tamanhos da ordem de grandeza do comprimento de onda da luz incidente 
tende a ser mais frontal $(g \rightarrow 1)$; e, quando a partícula é menor que o comprimento de onda (espalhamento Rayleigh), o espalhamento tende a ser isotrópico $(g \rightarrow 0)$. Em tecidos biológicos estruturas de diversos tamanhos podem realizar o espalhamento de fótons, portanto é interessante a experimentação com centros espalhadores em tamanhos diferentes.

As ME de vidro analisadas são comumente utilizadas para pintura de sinalização de vias, pois possuem um alto índice de refletividade melhorando a visibilidade ao serem iluminadas pelos faróis. Isso acontece porque a diferença de índices de refração entre ar e vidro é relativamente grande $\left(\Delta \mathrm{n}=\mathrm{n}_{\text {vidro }}-\mathrm{n}_{\mathrm{ar}} \approx 0,5\right)$. Quando a ME está inserida na resina $\left(\mathrm{n}_{\text {resina }}=1,54\right)$ a diferença de índices de refração é pequena $\left(\Delta n=n_{\text {resina }}-n_{\text {vidro }} \approx 0,04\right)$ isso leva a redução do espalhamento. O número de centros espalhadores nas amostras de $\mathrm{ME}$ de vidro é muito menor que nas de $\mathrm{Al}_{2} \mathrm{O}_{3}$ e isso diminui a probabilidade de interação.

\subsubsection{Transmissão:}

Os perfis de intensidade transmitida através das amostras com ME de vidro, iluminadas com laser $\mathrm{HeNe}(\lambda=633 \mathrm{~nm})$ e laser diodo infravermelho $(\lambda=820 \mathrm{~nm}$ ), estão na figura 3.9. Os resultados obtidos para $\lambda=633 \mathrm{~nm}$ foram colocados lado a lado com os de $\lambda=820 \mathrm{~nm}$ para facilitar a comparação entre eles. Os resultados para $\lambda=633 \mathrm{~nm}$ estão do lado esquerdo e para $\lambda=820 \mathrm{~nm}$ do lado direito. $I_{M}$ e $w$ para a amostra sem espalhador são diferentes nos dois casos, pois a intensidade incidente e a largura do feixe são diferentes nos dois lasers. 
Para facilitar a comparação de $I_{M}$ e da área sob o perfil as intensidades incidentes foram normalizados. Os valores normalizados de $I_{M}, w$ e da área sob o perfil de intensidade podem ser verificados na figura 3.10. Os traços conectando pontos nesse gráfico servem apenas para melhorar a visualização.

As intensidades máximas bem como a área sob a curva sofrem um decréscimo com o aumento da concentração que é aproximadamente exponencial. A largura do pico cresce de forma aproximadamente exponencial com a concentração, mas de forma bem menos abrupta que o decréscimo de $I_{M}$ que chega ser de quatro ordens de grandeza.

Comparando os $I_{M}$ vemos que não há diferenças significativas na atenuação causada pela diferença de comprimento de onda. As larguras de pico, para concentrações de $40-50 \%$ são maiores para $\lambda=633 \mathrm{~nm}$. A área sob a curva apresenta um comportamento semelhante ao de $I_{M}$ e é praticamente a mesma para os dois comprimentos de onda. 

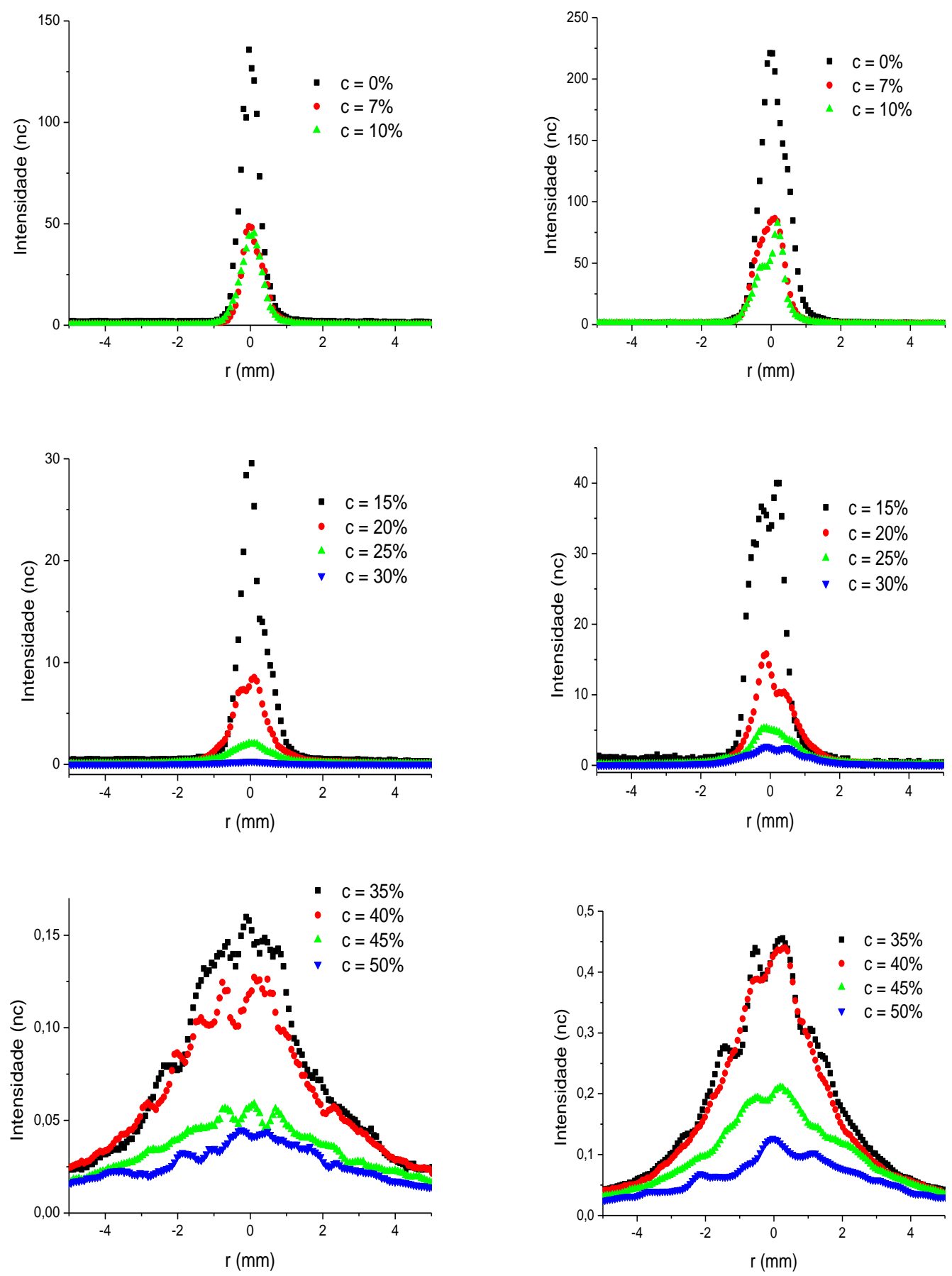

Figura 3.9: Perfis de intensidade transmitida por amostras de resina com $\mathrm{ME}$ de vidro iluminadas com $\lambda=633 \mathrm{~nm}$ (esquerda) e $\lambda=820 \mathrm{~nm}$ (direita). 

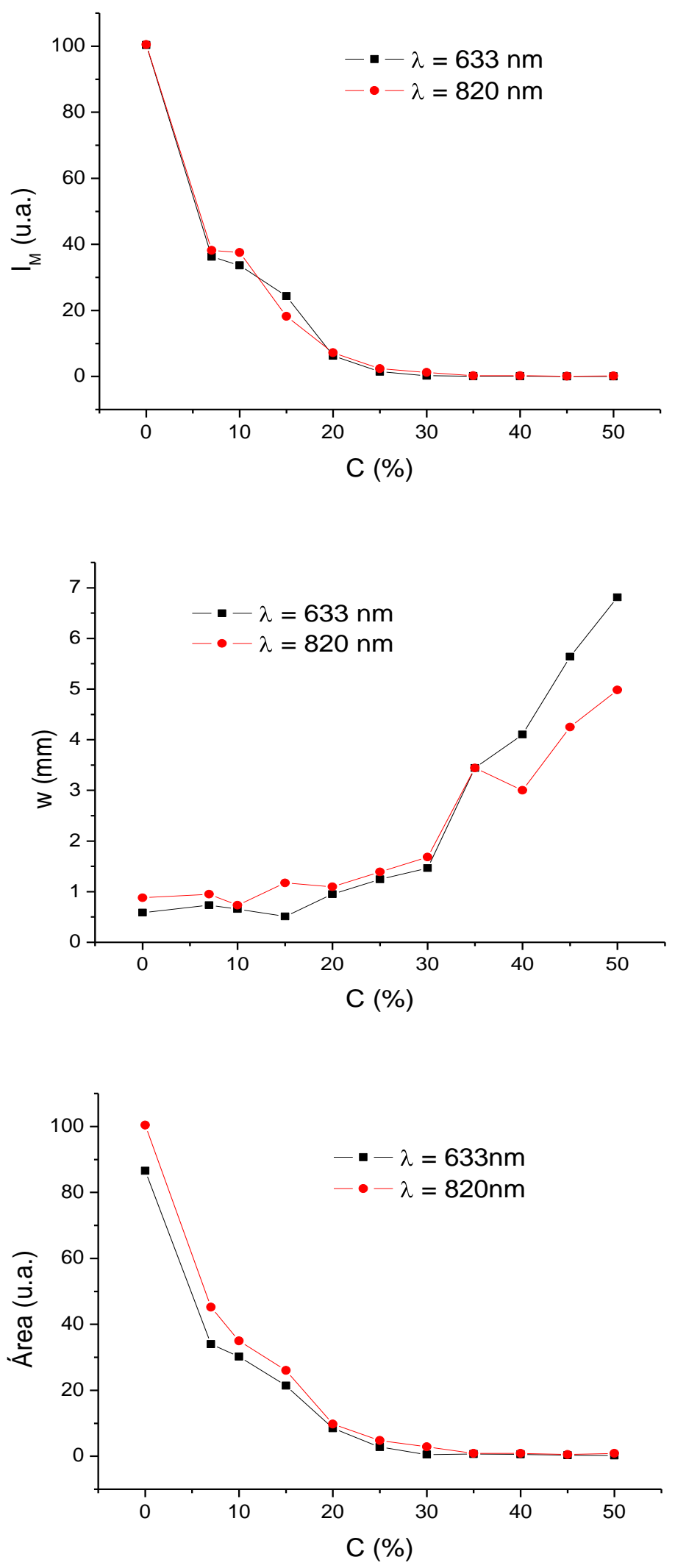

Figura 3.10: $I_{M}$, w e Área sob a curva para as amostras de resina com ME de vidro como espalhador, iluminadas com laser de $\lambda=633 \mathrm{~nm}$ e $\lambda=820 \mathrm{~nm}$. 


\subsection{Amostras de parafina:}

As moléculas de parafina, alcanos de cadeia longa (20 - 40 carbonos), dispersam bem a luz, por isso não foi necessária adição de espalhador nessas amostras. A parafina tem sido usada como matriz para simuladores óticos de diversos tecidos biológicos como osso, cerebelo, coração, rins, músculo e baço de ovelhas; cérebro. A utilização da parafina se deve, entre outros fatores, à facilidade de obtenção, ao baixo custo, ao fácil manuseio para a confecção de simuladores no formato desejado e à possibilidade de adição de corantes que são usados para alterar $\mu_{\mathrm{a}}$ e $\mu_{\mathrm{s}}$ para valores adequados a cada tecido simulado.

\subsubsection{Transmissão:}

Analisando o perfil das intensidades transmitidas por amostras com diferentes espessuras (figura 3.11) é possível verificar a redução na intensidade e o aumento de w com a espessura. (figura 3.12) 


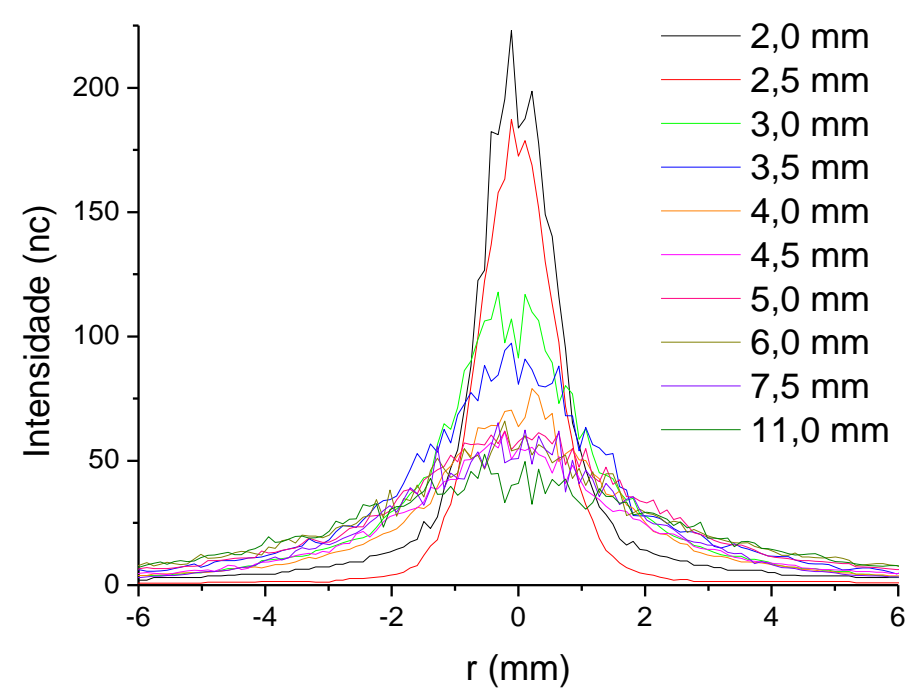

Figura 3.11: Perfis de intensidade para amostras de parafina.
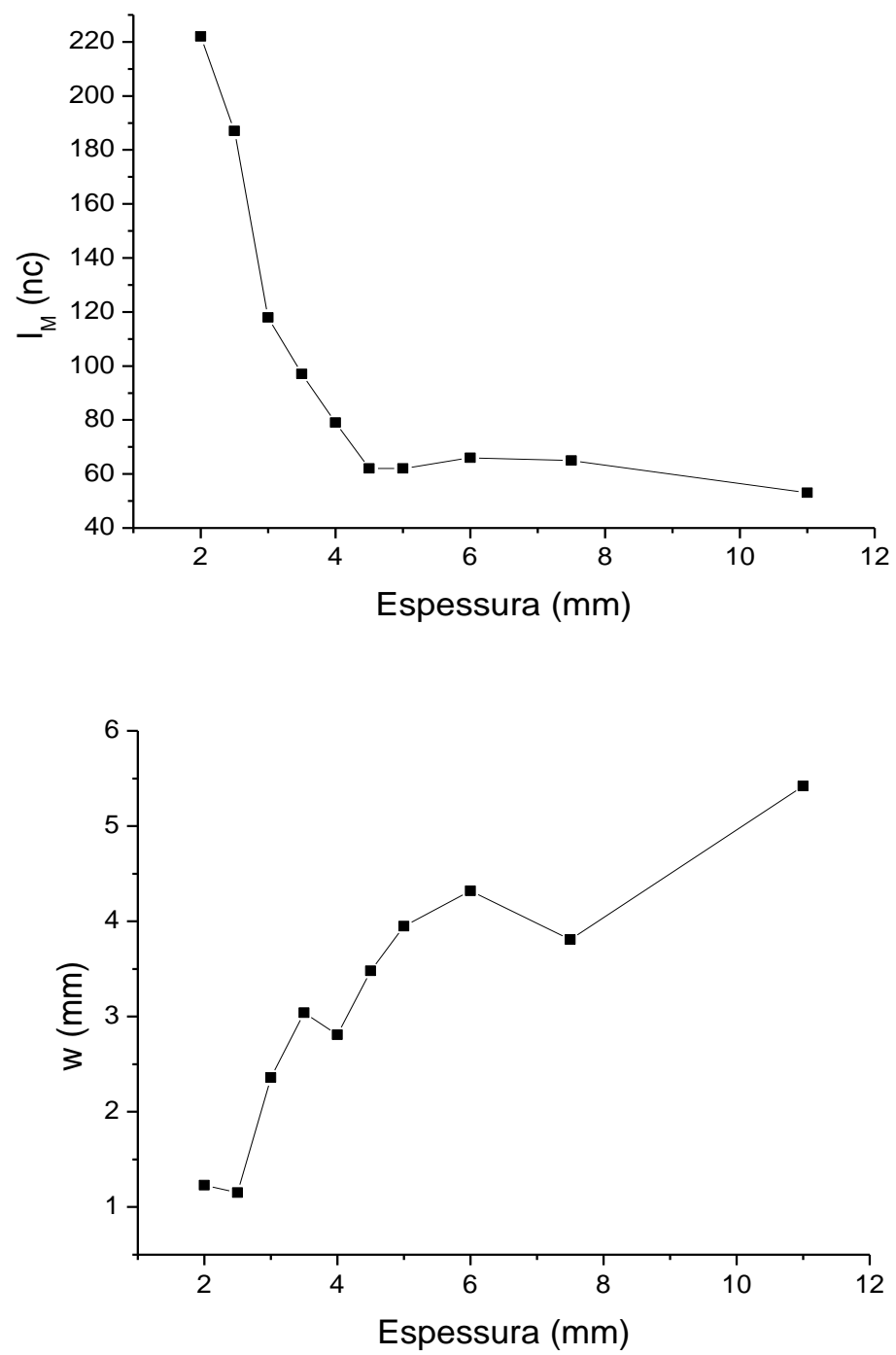

Figura 3.12: Intensidade máxima transmitida e largura do perfil para amostras de parafina. 


\subsubsection{Espalhamento a $90^{\circ}$ :}

Foi realizado um experimento de espalhamento de laser por amostra de parafina em que a distância (z) do feixe incidente em relação à superfície fotografada da amostra (plano xy) foi variada (figura 3.13).

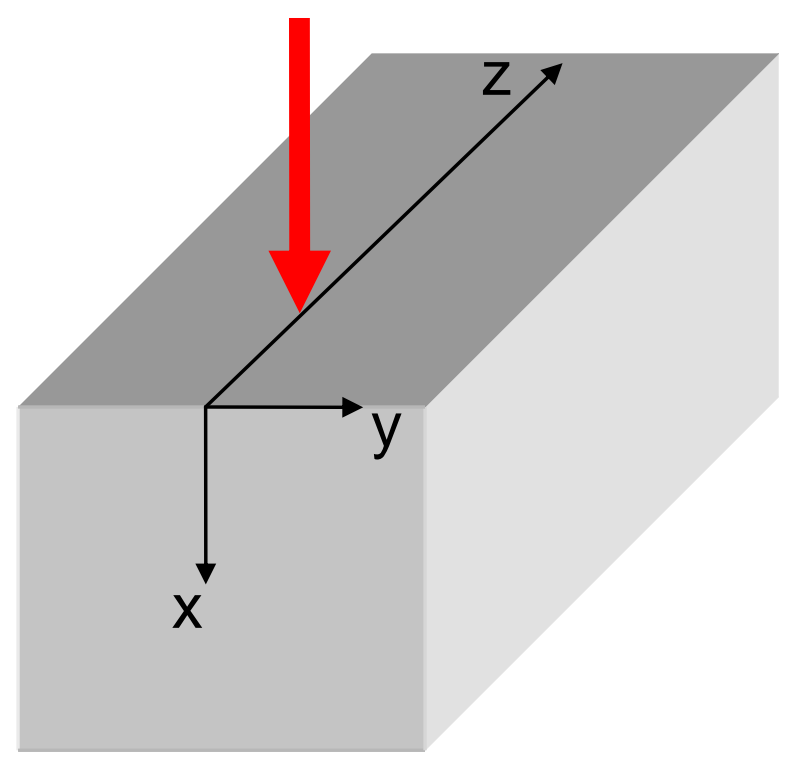

Figura 3.13: Pontos de incidência do laser no eixo z. As imagens são obtidas no plano $x y$.

A partir das imagens de espalhamento a $90^{\circ}$, no plano xy, é possível obter as intensidades em uma reta paralela ao feixe incidente na superfície da amostra (eixo x), como pode ser visto na figura 3.14. Embora esse experimento não detecte a intensidade dentro da amostra, ele é capaz de nos fornecer o perfil que essa intensidade interna tem, pois a intensidade que sai da amostra é aproximadamente uma fração da intensidade interna para aquela distância z. Nesse experimento adotamos $z=0$ na superfície $(x y)$ da amostra. 


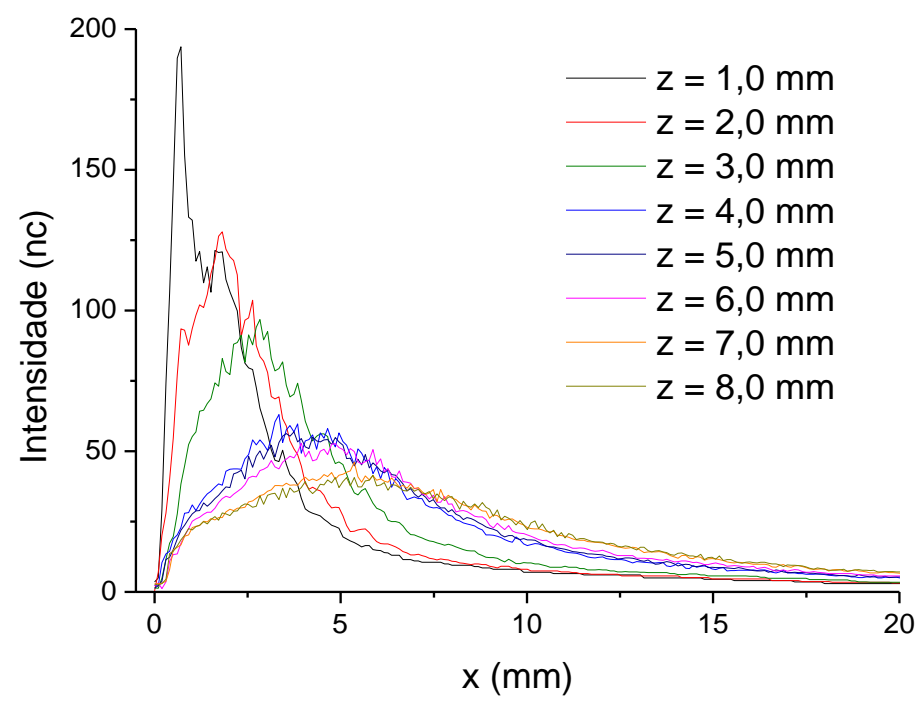

Figura 3.14: Intensidades espalhadas a $90^{\circ}$, na amostra de parafina, para distâncias $z$ variando de 1,0 a 8,0 mm.

A intensidade máxima, a profundidade em que ela ocorre, a largura do pico e o coeficiente de atenuação assintótico para as dadas posições de incidência são dados na figura 3.15.

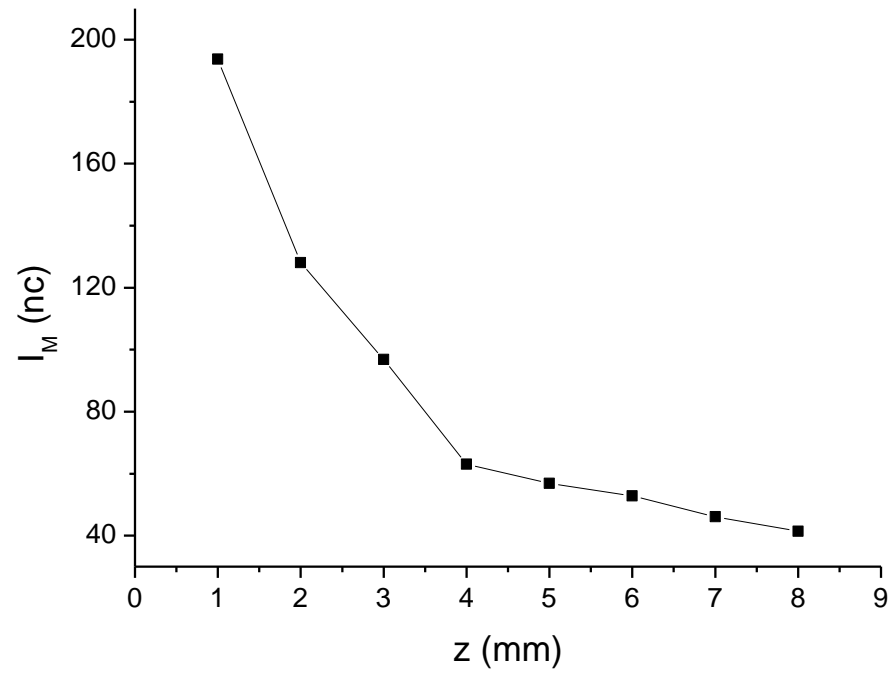

Figura 3.15: $I_{M}, x\left(I_{M}\right), w, \mu_{a s}$ variando com $z$ para espalhamento a $90^{\circ}$ das amostras de parafina. (continua) 

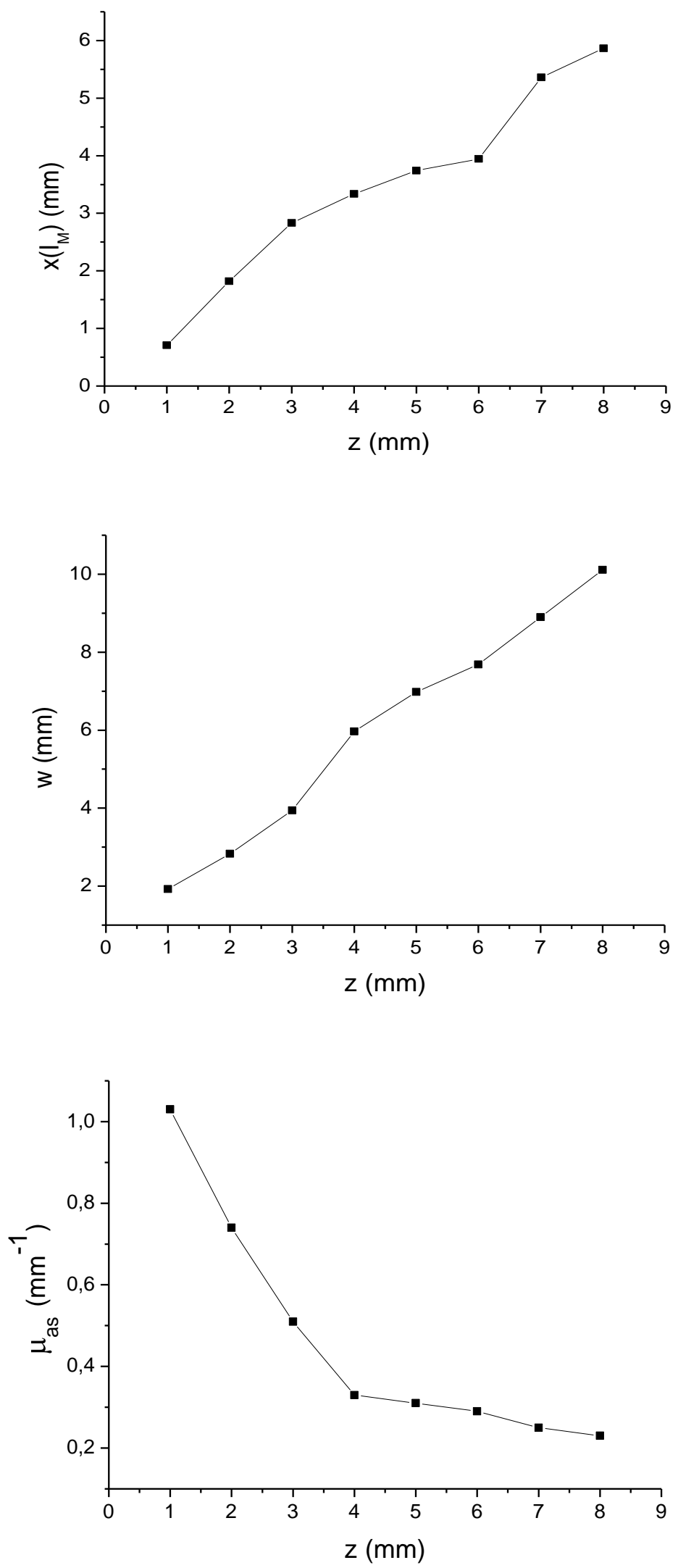

Figura 3.15: $I_{M}, x\left(I_{M}\right), w, \mu_{a s}$ variando com $z$ para espalhamento a $90^{\circ}$ das amostras de parafina. 
3.6 Tecido Suíno. (Saito et al, 2009)

As amostras de tecido biológico são muito mais complexas que as manufaturadas, pois não é mais possível considerar apenas absorção ou espalhamento isoladamente; a amostra não é mais considerada homogênea e as interfaces não são superfícies regulares, planas e perpendiculares ao feixe. A soma das espessuras das partes separadas é ligeiramente diferente da espessura da amostra com os tecidos ainda juntos (como pode ser verificado na tabela 2.5) isso se deve a perda de material e a deformação da amostra devido ao corte.

\subsubsection{Amostra inteira.}

A amostra inteira é formada por camadas de pele, tecido adiposo e músculo. A figura 3.16 mostra esquematicamente como a luz se difunde na amostra. Os tamanhos das setas são proporcionais às intensidades. A atenuação causada por espalhamento e absorção está representada pela diminuição das setas ao atravessar as camadas; as reflexões e refrações nas interfaces também estão representadas. 


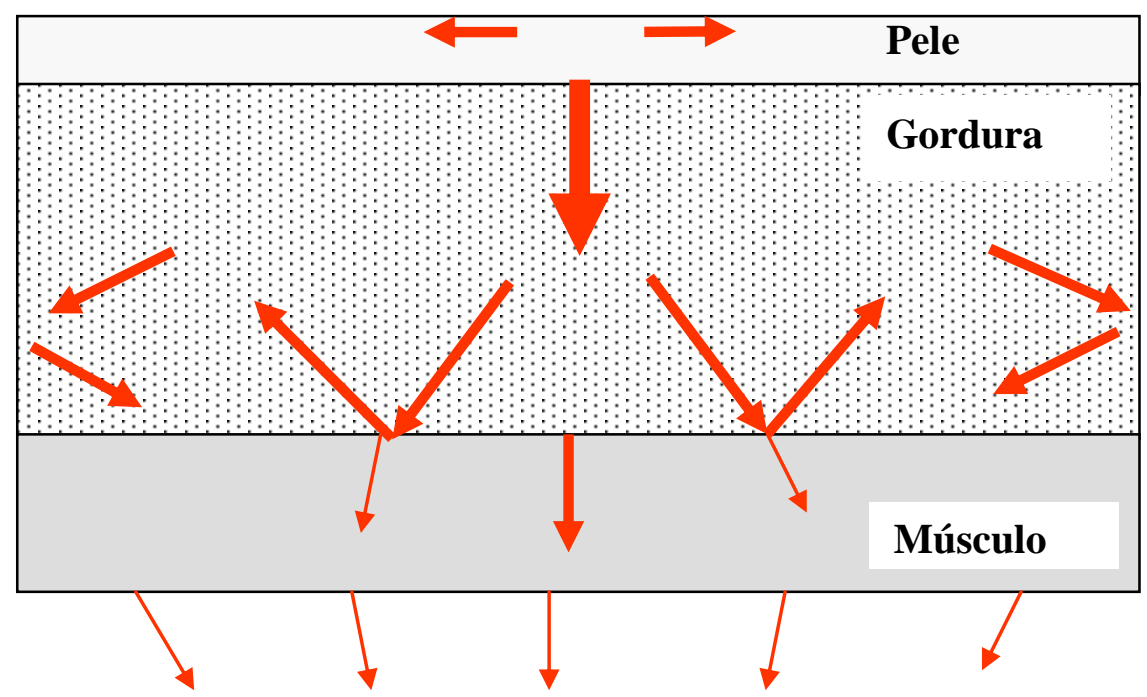

Figura 3.16: Esquema representando a transmissão da luz por amostra de tecido biológico. As setas têm espessuras proporcionais às intensidades.

\subsubsection{Transmissão:}

A atenuação da intensidade luminosa observada no experimento de transmissão ocorre devido a diferentes fatores como: espalhamento e absorção de fótons e reflexão nas interfaces entre meios com índices de refração diferentes. Mesmo com as complicações já citadas, as imagens formadas pelos fótons ao atravessar a amostra continuam sendo radialmente simétricas (figura 3.17), e o perfil de intensidades transmitidas, normalizadas pelas intensidades incidentes, na direção das setas da figura 3.17, se mantém próximo ao gaussiano. (figura 3.18)
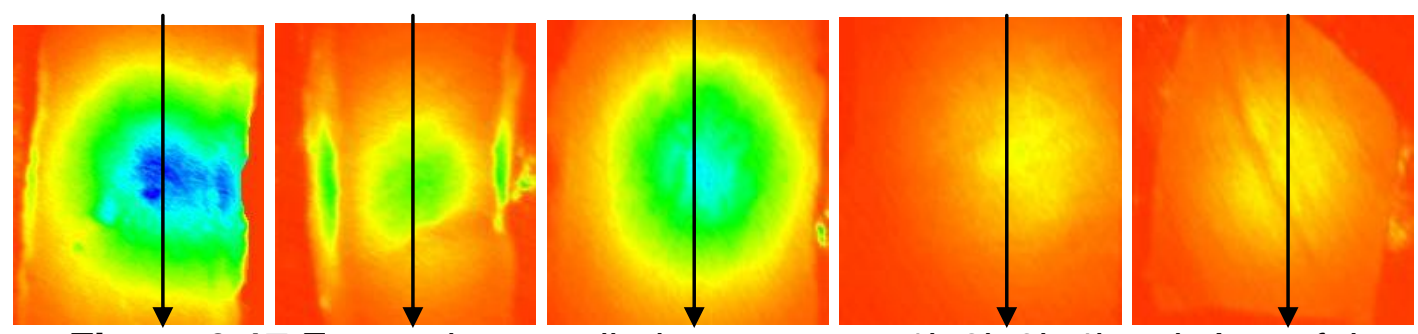

Figura 3.17 Esquerda para direita: amostras 1i, 2i, 3i, 4i e 5i. A cor foi modificada para melhorar a visualização. Nesse sistema de cores vermelho representa intensidades baixas, e azul intensidades maiores. As intensidades não estão normalizadas. 


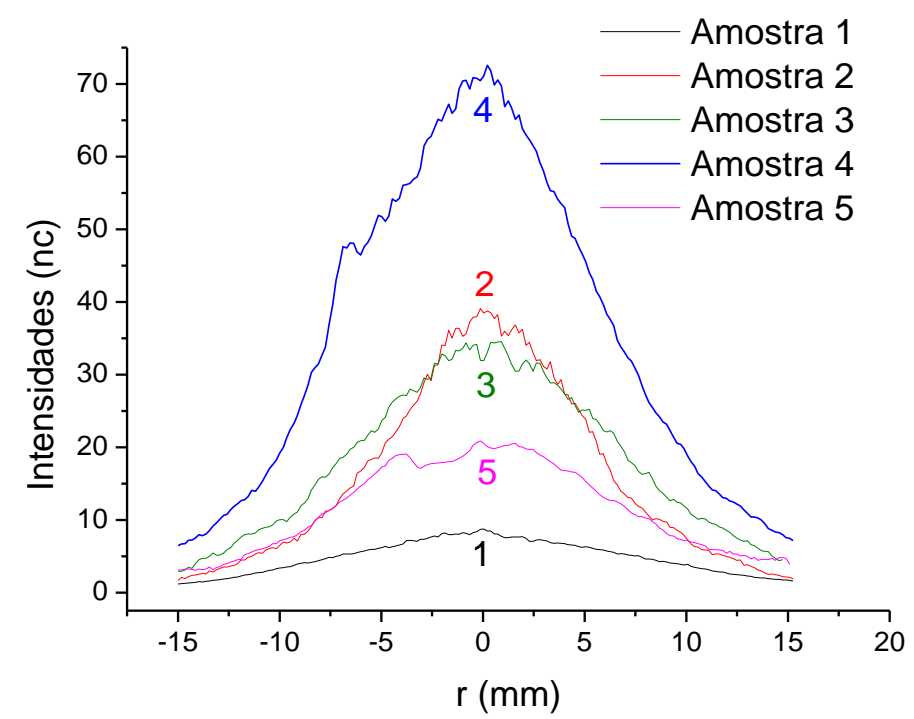

Figura 3.18 Perfil de intensidades transmitidas por amostras inteiras de tecido suíno.

É interessante notar na figura 3.17 que a amostra 2 apresenta máximos nas bordas laterais, pois a luz é parcialmente refletida na lateral tecido / ar. $\mathrm{Na}$ amostra 5 é possível verificar linhas de baixa intensidade transmitida que são explicadas pelo alinhamento de fibras musculares.

$I_{M}$, w e a área sob a curva dos perfis de intensidades mostrados na figura 3.18 dependem da espessura da amostra (figura 3.19). 

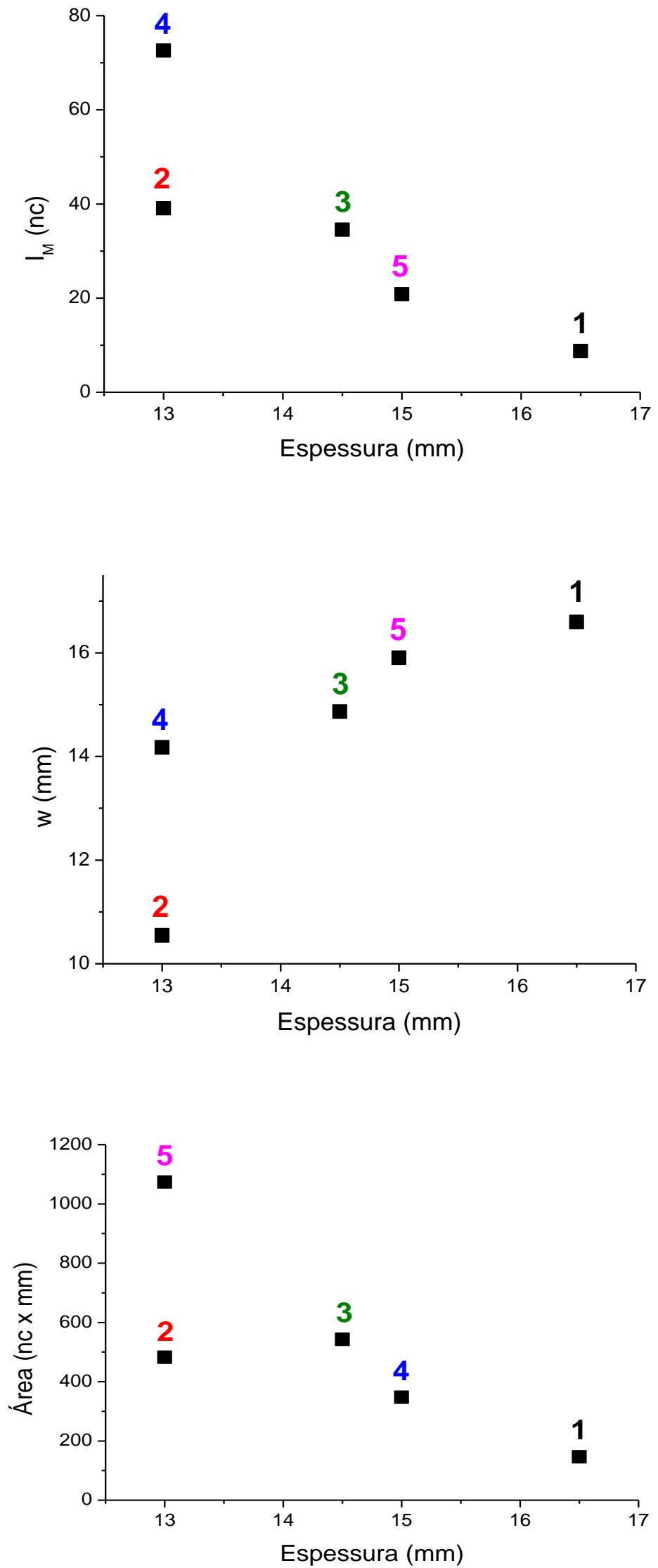

Figura 3.19: $I_{M}$, w e Área sob a curva para os perfis apresentados na figura 3.18. 
Ao atravessar a primeira camada (pele) à intensidade diminui principalmente devido a reflexão na interface com o ar e a absorção causada, principalmente, pela melanina. Na camada de tecido adiposo o espalhamento é mais relevante que nas outras camadas, isso leva a uma grande atenuação do feixe na direção frontal e a um maior espalhamento para as laterais. A última camada, formada por músculo, recebe relativamente poucos fótons, pois grande parte deles foi absorvida e grande parte dos que foram espalhados chegam à interface tecido adiposo / músculo com ângulos diferentes de zero aumentando a probabilidade de serem refletidos. A camada de músculo reduz ainda mais a intensidade do feixe. A luz laser sai de vários pontos da superfície inferior da amostra em varias direções, mas somente os fótons que vão em direção à CCD formarão a imagem.

O aumento da espessura faz com que o número de centros absorvedores e espalhadores aumentem. Consequentemente, observamos a diminuição de $I_{M}$ e da área sob a curva. A largura do perfil (w) permanece praticamente constante. Essas observações não se aplicam à amostra 2. Uma possível explicação para essa diferença da amostra $2 \mathrm{em}$ relação ao comportamento do grupo é a espessura da camada de tecido adiposo que é a maior de todas as amostras e representa $60 \%$ da espessura dessa amostra. 0 coeficiente de atenuação do tecido adiposo é maior que os de pele e músculo. Portanto, embora a espessura da amostra 2 inteira seja pequena, $I_{M}$ e a área sob a curva são baixos, pois houve forte atenuação na camada de tecido adiposo. Era de se esperar que a largura do perfil da amostra 2 fosse maior, no entanto o valor dele é pequeno em comparação aos demais, que são praticamente iguais. Isso pode ser explicado pelo aumento da probabilidade de 
reflexão com o aumento do ângulo de chegada do fóton à interface tecido adiposo / músculo. Por isso os fótons que contribuiriam para um aumento da largura do perfil não chegam a sair da amostra pela interface músculo / ar e, portanto, não são detectados.

\subsubsection{Espalhamento $90^{\circ}$ :}

A lateral das amostras, iluminadas com laser e luz ambiente, pode ser vista na figura 3.20. As amostras foram iluminadas em sua superfície superior por um feixe de laser HeNe $(\lambda=633 \mathrm{~nm})$ e fotografadas pela lateral (figura 3.21). Os perfis de intensidade da luz espalhada a $90^{\circ}$ na direção e sentido das setas da figura 3.21 foram normalizados de forma tal que todos tivessem a mesma intensidade máxima. Esses perfis estão representados na figura 3.22.
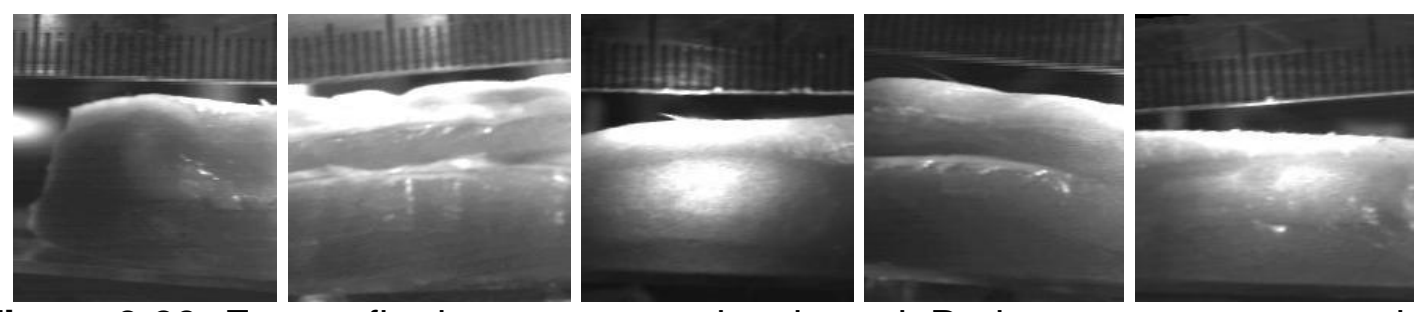

Figura 3.20: Fotografia das amostras, vista lateral. Podemos notar as camadas bem definidas nessas imagens.
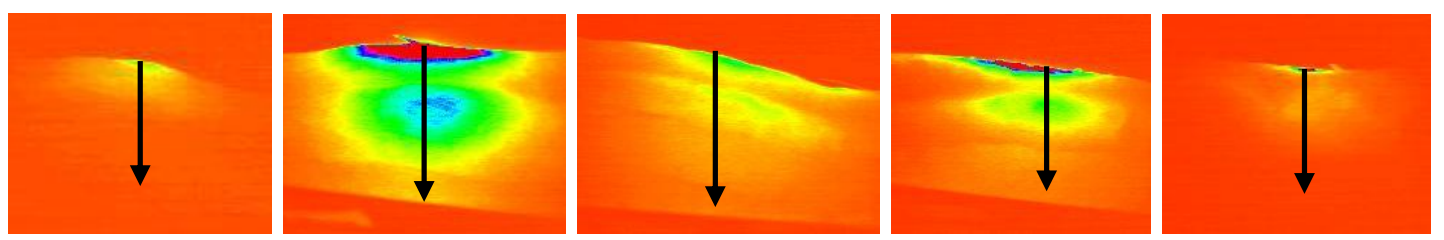

Figura 3.21: Amostras iluminadas somente com laser e fotografadas pela lateral. Os perfis de intensidade são obtidos na direção e sentido das setas. 

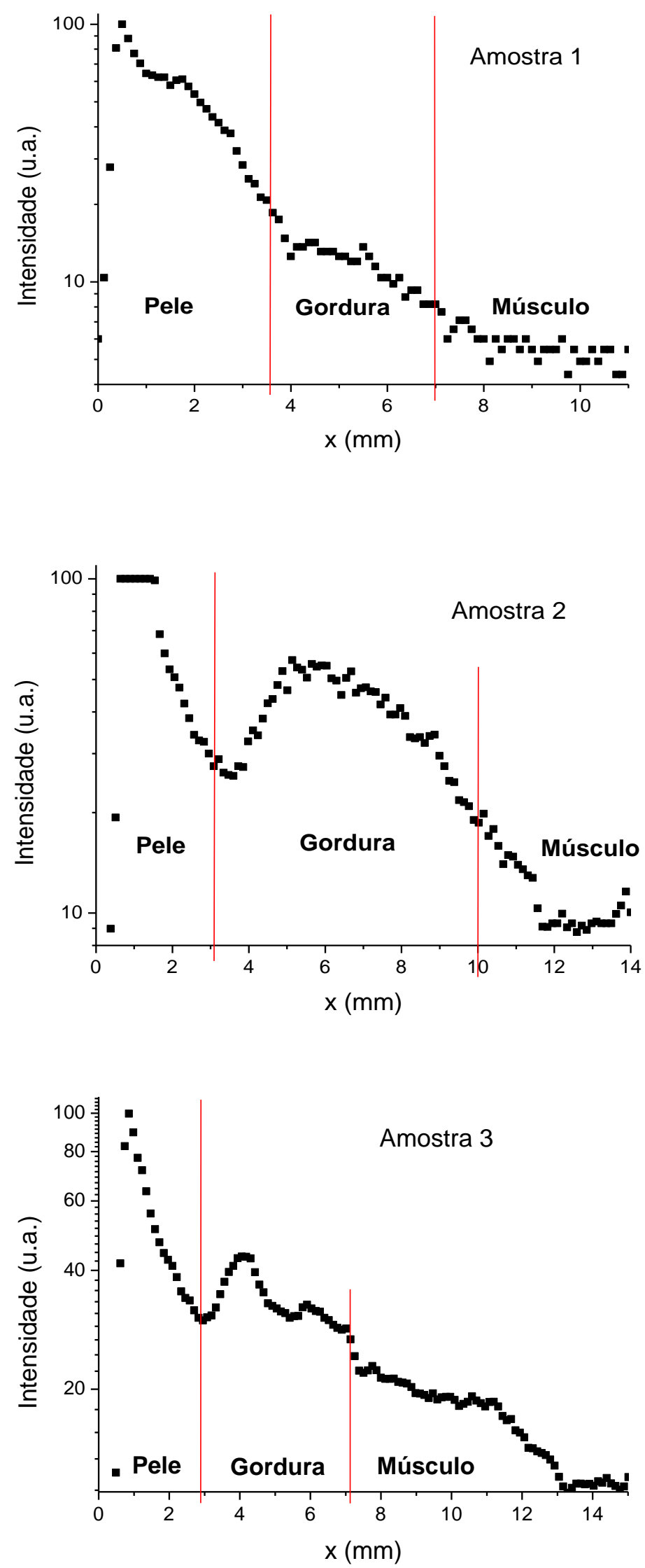

Figura 3.22: Perfil de intensidade espalhada a $90^{\circ}$ para as 5 amostras inteiras. (continua) 

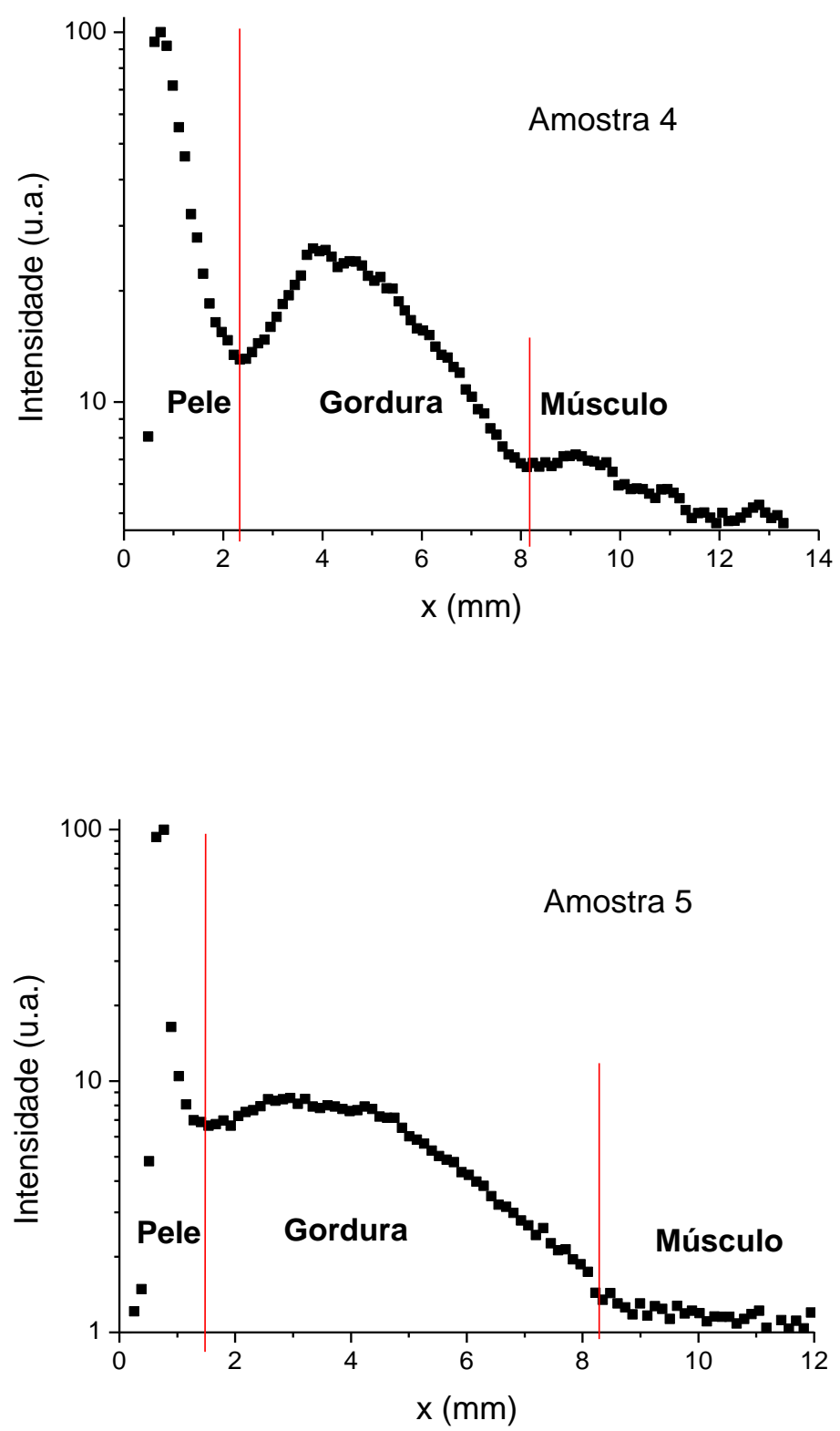

Figura 3.22: Perfil de intensidade espalhada a $90^{\circ}$ para as 5 amostras inteiras.

O comportamento geral dos perfis de intensidade espalhada é de um aumento até atingir um máximo ainda na camada de pele, seguido de uma queda, aproximadamente exponencial, até a interface com a camada de tecido adiposo. Nessa camada o espalhamento é intenso o suficiente para produzir um novo máximo, e, na camada de músculo a intensidade espalhada já está muito baixa e tende a cair ainda mais. 
A amostra 1 tem uma grande espessura de pele e muito da intensidade foi atenuada nessa camada. A intensidade espalhada na pele da amostra 2 foi suficiente para saturar a medida da câmera. E a camada de tecido adiposo dessa amostra é a maior dentre todas as amostras, isso faz com que grande parte da luz espalhada seja proveniente dessa camada. Os experimentos com simuladores com concentrações uniformes de centros espalhadores mostram que não há a formação de máximos secundários como os que aparecem nas camadas de tecido adiposo das amostras de tecido suíno. Isso nos leva a conjecturar que as amostras de tecido adiposo espalham mais que as de pele, pois se assim não fosse elas tenderiam a continuar a redução de intensidade sem o aparecimento desse segundo máximo de intensidade.

A amostra 3 tem uma camada de músculo mais espessa que as restantes, mas mesmo assim não há a formação de um terceiro máximo de intensidade. Isso evidência que o tecido muscular tem uma característica de atenuação mais ligada à absorção que ao espalhamento, em oposição ao que acontece com o tecido adiposo.

\subsubsection{Amostra de pele:}

As amostras de pele foram retiradas das amostras do tecido inteiro e tinham uma espessura muito pequena, quando isoladas, impossibilitando as medidas de espalhamento a $90^{\circ}$. Essas amostras apresentaram uma visível desidratação. 


\subsubsection{Transmissão:}

As amostras só de pele têm espessuras (e) pequenas e praticamente iguais dentro da incerteza $(<\mathrm{e}>=1,62 \mathrm{~mm} \pm 0,29 \mathrm{~mm}$ ). No entanto, dispersam a luz, aumentam a largura do feixe gaussiano que o atravessa. A largura do feixe incidente é $w_{\text {feixe }}=1,18 \mathrm{~mm} \pm 0,05 \mathrm{~mm}$, mas a largura média dos perfis é $<\mathrm{W}>=1,64 \pm 0,30$. As intensidades transmitidas variam muito entre as amostras, mas isso não pode ser atribuído a diferenças nas espessuras. Os perfis de intensidade transmitida através das amostras podem ser visto na figura 3.23 .

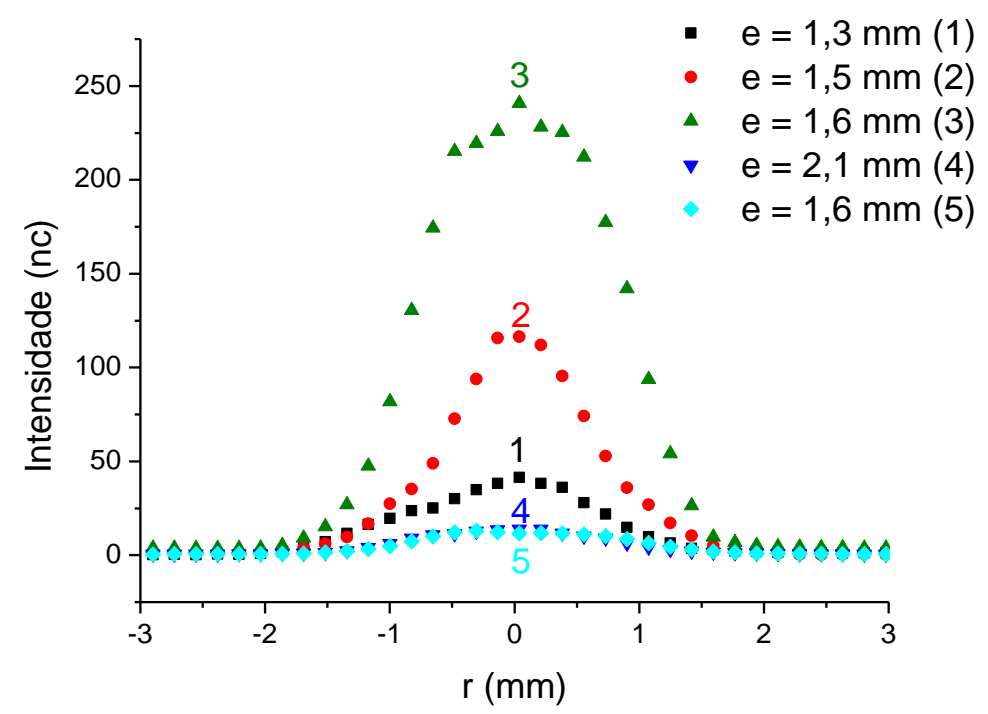

Figura 3.23: Perfil de intensidade transmitida através das cinco amostras só de pele. O número de cada amostra está entre parênteses.

\subsubsection{Amostras de tecido adiposo:}

Este tecido apresenta um fator de anisotropia pequeno $(\mathrm{g}=0,77)$ (Flock et al, 1987) quando comparado à maioria dos outros tecidos biológicos. Portanto, o espalhamento decorrente de interações da luz com moléculas do 
tecido adiposo resulta em uma maior abertura do feixe. Esse fato pôde ser observado neste trabalho, como mostram os resultados a seguir.

\subsubsection{Transmissão:}

O perfil de transmissão para as amostras só com tecido adiposo são apresentados na figura 3.24. A intensidade máxima diminui e w aumenta com espessura da amostra como era de se esperar (figura 3.25).

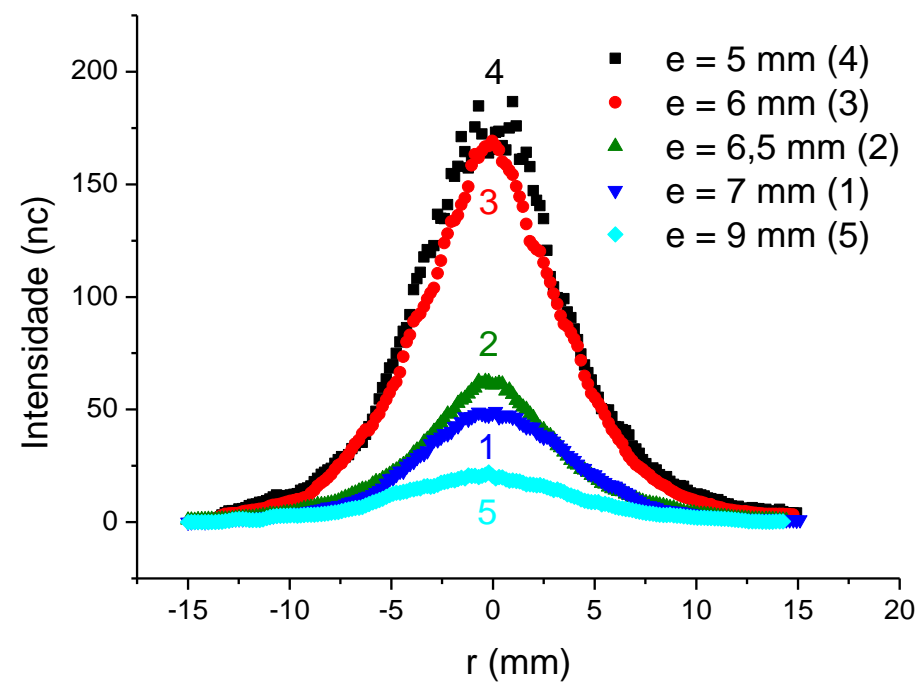

Figura 3.24: Perfil de intensidade transmitida através das cinco amostras só de tecido adiposo. O número de cada amostra está entre parênteses. 

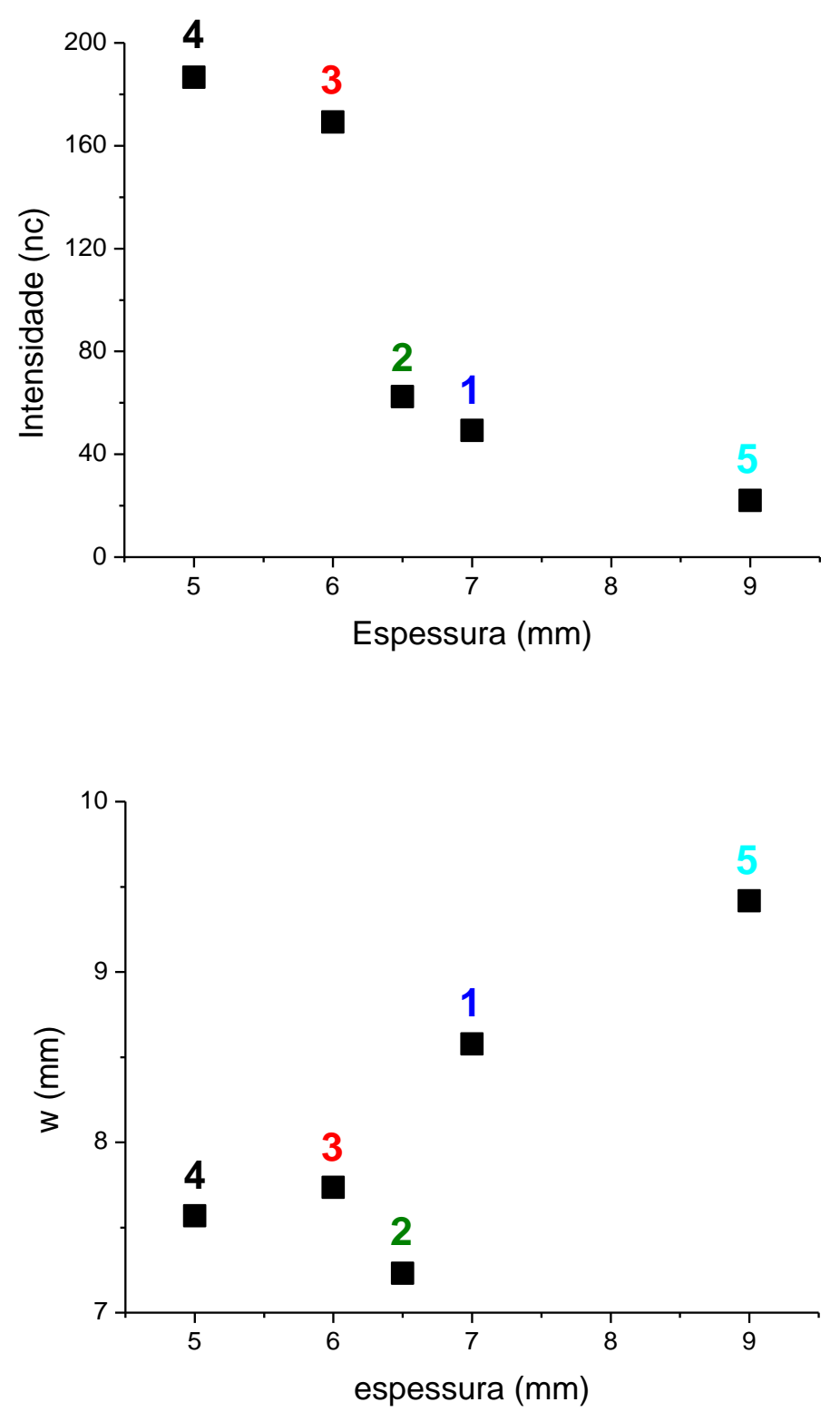

Figura 3.25: $I_{M}$ e w para amostra só de tecido adiposo, em função da espessura da amostra.

\subsubsection{Espalhamento a $90^{\circ}$ :}

Para medida de espalhamento a $90^{\circ}$ a espessura da amostra não tem relevância, por isso todas as amostras foram analisadas em conjunto. Cada amostra foi iluminada em dois pontos diferentes, mas próximos, gerando dez perfis que foram normalizados de tal forma que todos tivessem intensidades 
máximas iguais. Em seguida os perfis foram usados para obtermos a média e o desvio padrão ponto a ponto. $O$ perfil apresentado na figura 3.26 é o dos valores médios de intensidade dos perfis das dez medidas, e as barras de incerteza são os desvios padrão correspondentes.

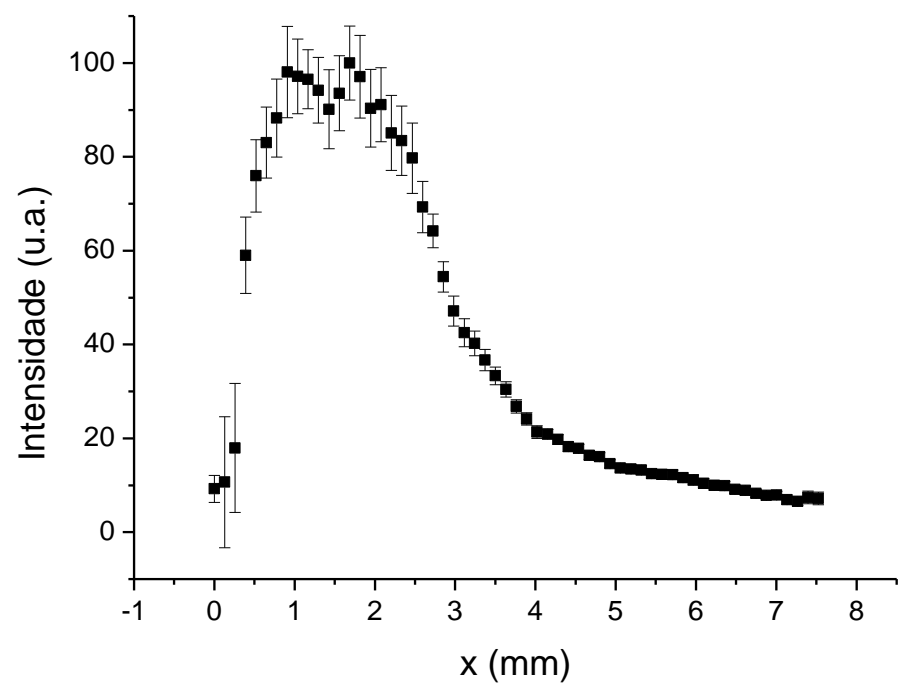

Figura 3.26: Média e desvio padrão de 10 perfis de espalhamento a $90^{\circ}$ obtidos das 5 amostras só de tecido adiposo.

O perfil de espalhamento a $90^{\circ}$ das amostras de tecido adiposo apresenta crescimento rápido inicial seguido de um decréscimo assintoticamente exponencial. Esse comportamento é típico de sistemas onde o espalhamento é muito mais relevante do que a absorção, como nas amostras de resina com $\mathrm{Al}_{2} \mathrm{O}_{3}$ alfa como espalhador.

\subsubsection{Amostra de músculo:}

O fator de anisotropia para músculo, segundo Wilksch e colaboradores (1984), é 0,97. Portanto, o espalhamento por esse tipo de tecido é fortemente 
frontal. Neste trabalho foi usado músculo de porco recém-abatido, portanto, ainda com a presença de sangue na amostra.

\subsubsection{Transmissão:}

Os perfis de intensidade da luz transmitida através das amostras de músculo estão apresentados na figura 3.27 ; $I_{M}$ e w para esses perfis estão na figura 3.28.

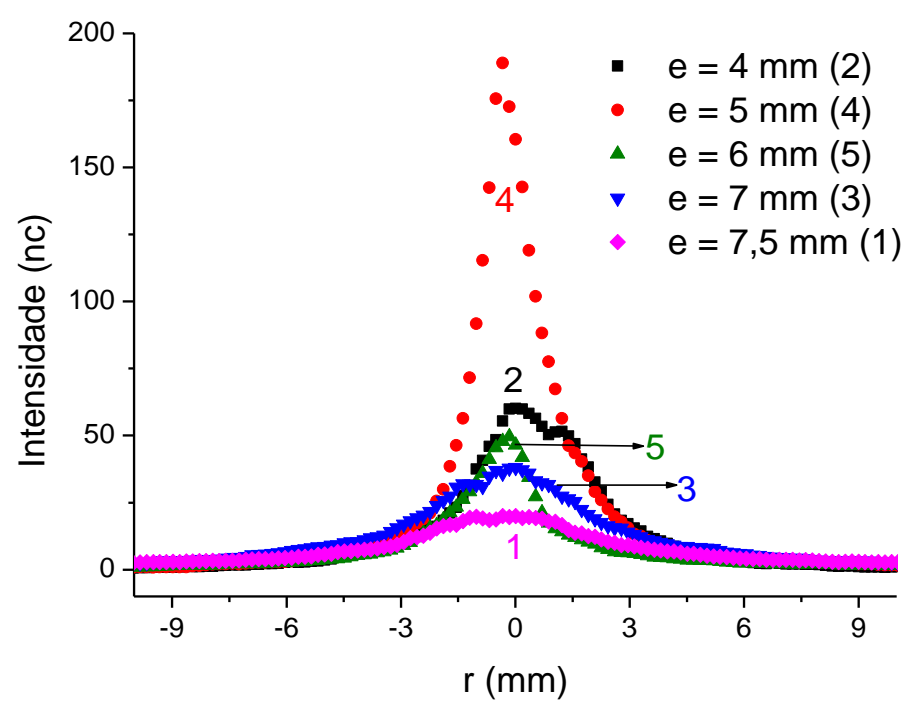

Figura 3.27: Perfil de intensidade transmitida através das cinco amostras só de músculo. O número de cada amostra está entre parênteses. 

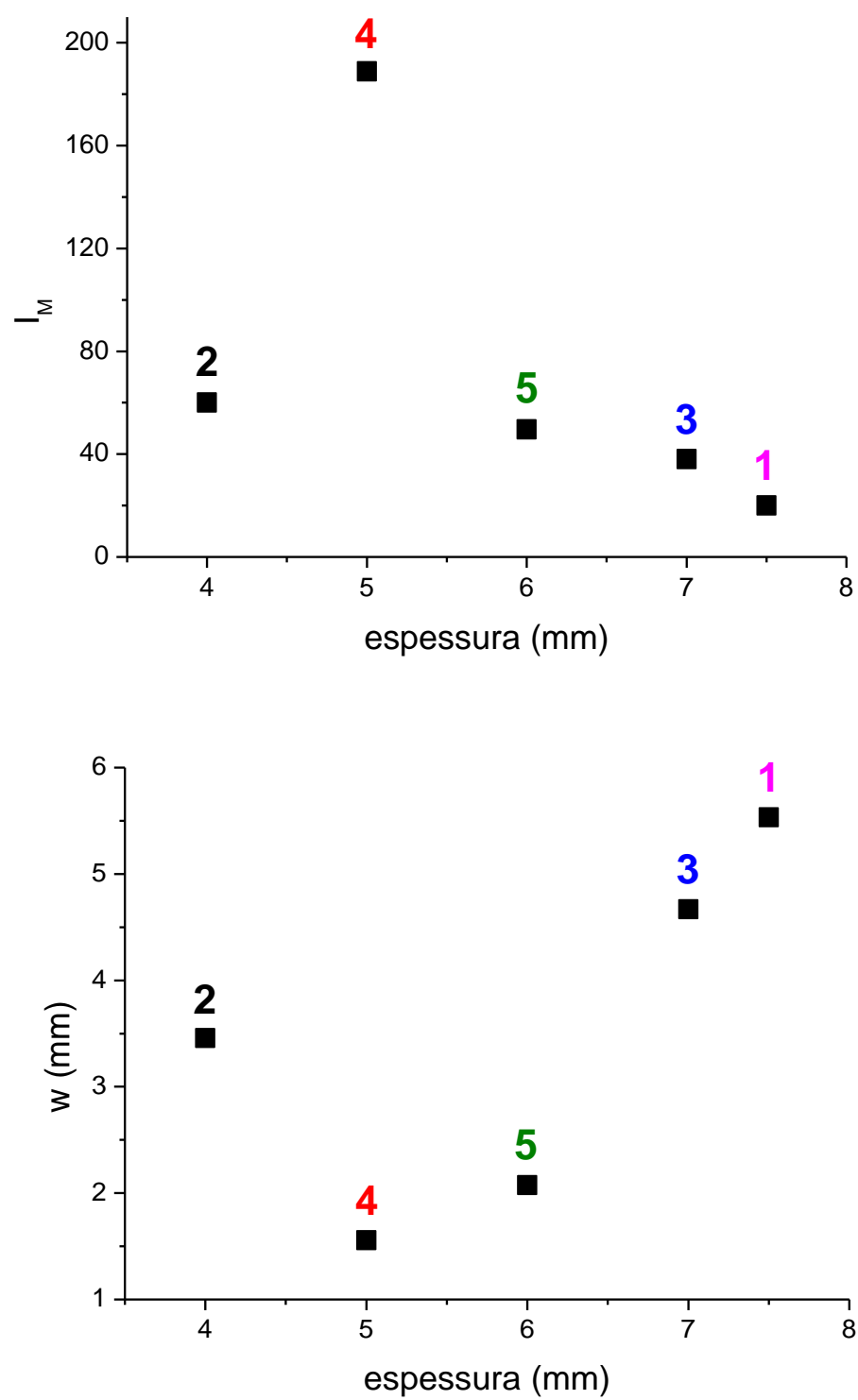

Figura 3.28: IM e w para perfis de transmissão de amostras só de músculo, em função da espessura da amostra.

A intensidade máxima diminui e w aumenta com o aumento da espessura, exceto para a amostra 2, provavelmente porque ela apresenta uma pequena camada de tecido adiposo. É importante notarmos que as aberturas dos perfis são bem menores que as propiciadas pelas amostras de tecido adiposo com espessuras semelhantes, e isso se deve ao g que é maior para a tecido adiposo que para o músculo. 


\subsubsection{Espalhamento $90^{\circ}$ :}

As amostras foram iluminadas em dois pontos diferentes cada, gerando dez perfis que foram normalizados de tal forma que todos tivessem intensidades máximas iguais. Em seguida os perfis foram usados para obtermos a média e o desvio padrão ponto a ponto. O perfil apresentado na figura 3.29 é a média com o desvio padrão dos perfis das dez medidas.

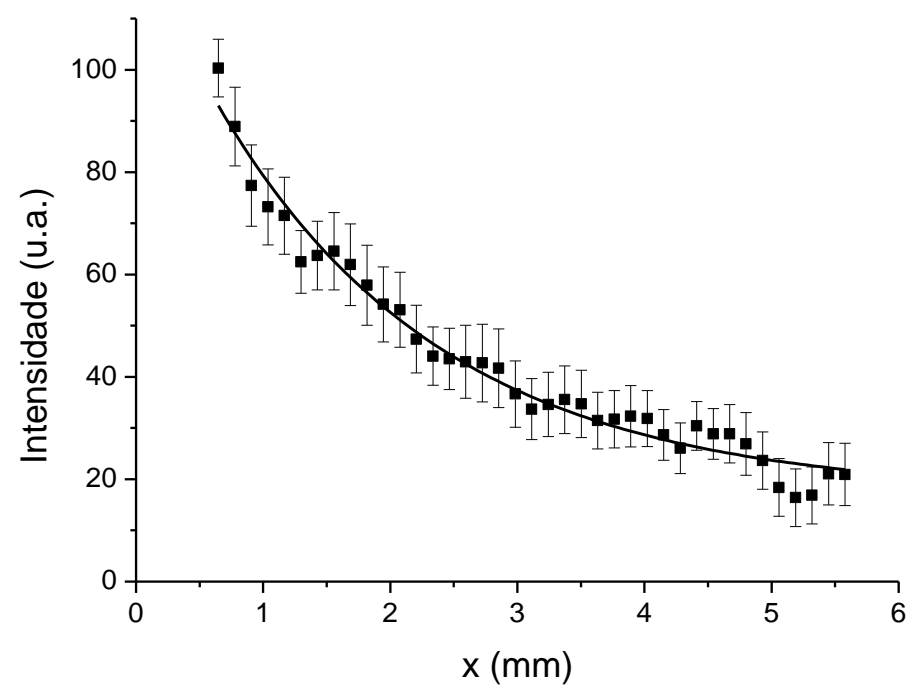

Figura 3.29: Média e desvio padrão de 10 perfis de espalhamento a $90^{\circ}$ obtidos das 5 amostras só de músculo. A curva apresentada é um ajuste exponencial.

A intensidade diminui exponencialmente com a profundidade. Esse é um comportamento típico para sistemas em que há mais absorção que espalhamento como nas amostras de melanina diluída em água.

\subsection{Dedos:}

As medidas de espessura dos dedos, feitas no meio das falanges mediais dos 48 voluntários, são apresentados no histograma da figura 3.30. A 
espessura média dos dedos é de 14,0 (15) $\mathrm{mm}$. As cores de peles dos voluntários foram separadas em 3 grupos de tonalidades: grupo 1 os de pele mais clara, grupo 3 os de pele mais escura e grupo 2 os de cores intermediárias. Essa classificação foi feita de forma visual, e representa apenas uma forma qualitativa de análise. Há 20 voluntários classificados no grupo 1, 25 no grupo 2 e apenas 3 no grupo 3 . Para avaliar as intensidades transmitidas foram analisadas as intensidades dentro de um quadrado com 2500 pixels (4,3 mm de lado) na região de incidência do laser.

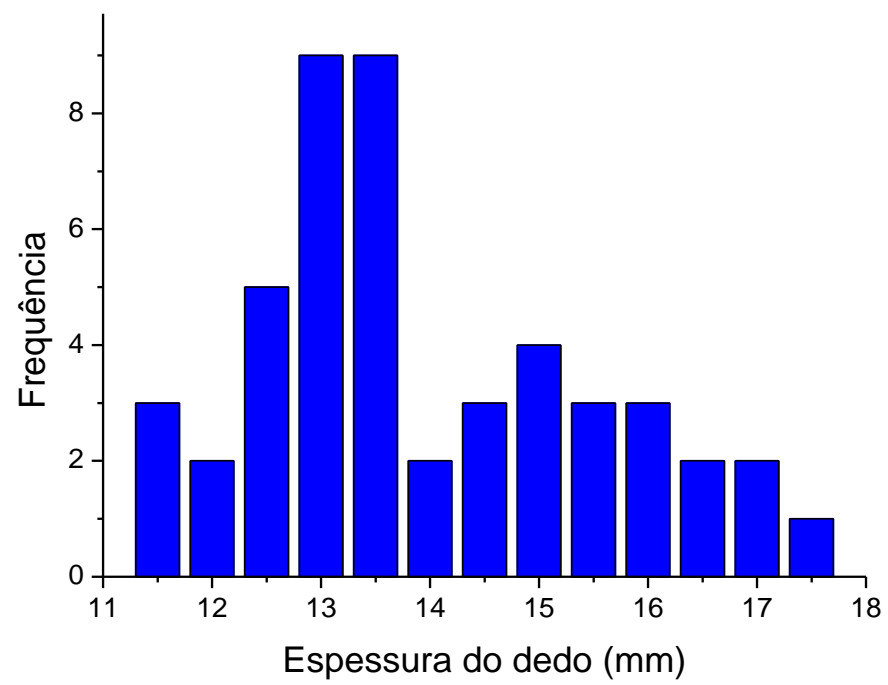

Figura 3.30: Histograma das espessuras dos dedos de 48 voluntários.

\subsubsection{Análise Quantitativa:}

A intensidade incidente foi de $6,94 \mathrm{~mW}$ tanto para $\lambda=633 \mathrm{~nm}$ quanto para $\lambda=820 \mathrm{~nm}$. A intensidade média transmitida na região do feixe varia com a espessura dos dedos, para os três grupos, como pode ser visto na figura 3.31 para $\lambda=633 \mathrm{~nm}$ e na figura 3.32. para $\lambda=820 \mathrm{~nm}$. Os ajustes lineares indicam a tendência de cada grupo. 


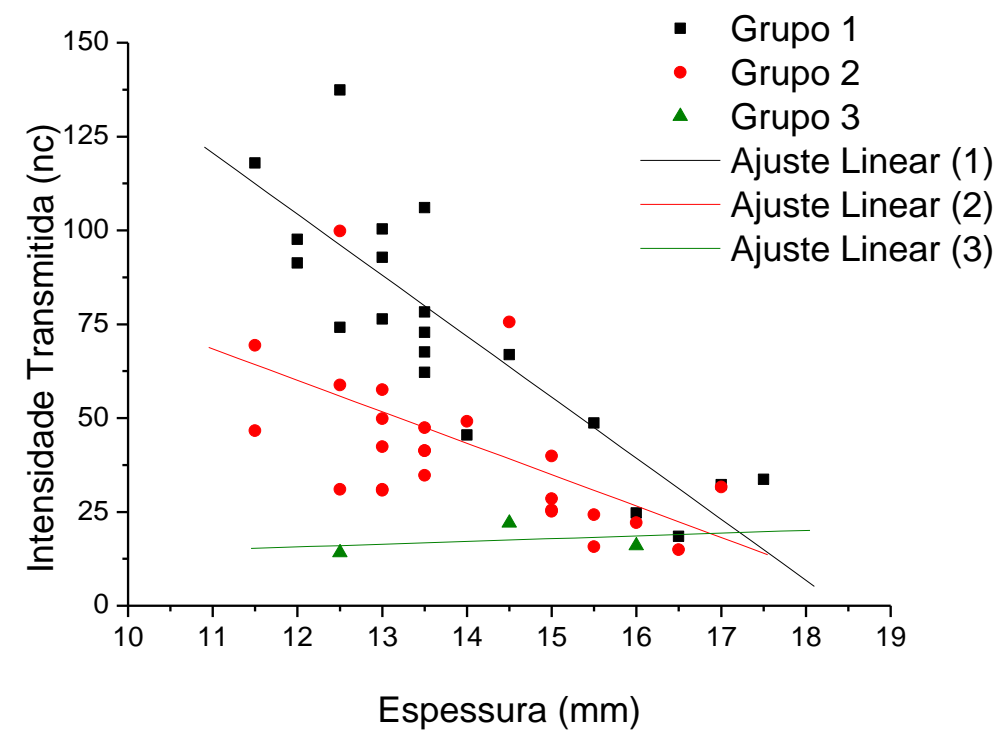

Figura 3.31: Intensidade transmitida pelos dedos para $\lambda=633 \mathrm{~nm}$.

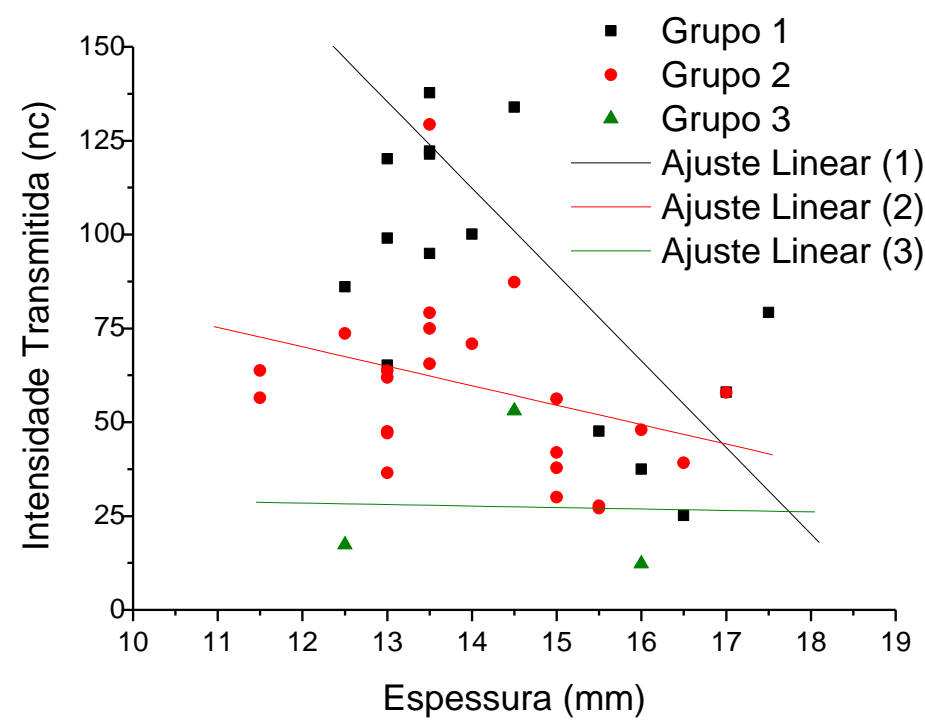

Figura 3.32: Intensidade transmitida pelos dedos para $\lambda=820 \mathrm{~nm}$.

Ao compararmos os três grupos percebemos que a intensidade transmitida é maior para o grupo 1 e menor para o grupo 3 , pois a concentração de melanina é um fator muito importante para a atenuação do feixe. Para os grupos 1 e 2 a intensidade também diminui com a espessura dos dedos enquanto que no grupo 3 as intensidades praticamente não variam com a espessura. Ressalvado o pequeno tamanho desse grupo, isso significa que para o grupo 3 a atenuação é principalmente causada por absorção na pele. 
$\mathrm{Na}$ figuras 3.31 e 3.32 o coeficiente angular das retas ajustadas para o grupo 1 é maior que para as do grupo 2. Esse fato mostra que, para o grupo 1, a espessura do dedo é mais relevante para alterar a intensidade transmitida que para o grupo 2 .

Quando comparamos as intensidades transmitidas pelo mesmo dedo para os dois feixes (figura 3.33) fica claro que o feixe do laser infravermelho $(\lambda=820 \mathrm{~nm})$, é menos atenuado que o feixe do laser vermelho $(\lambda=633 \mathrm{~nm})$, para os grupos 1 e 2 . A causa é o fato de a melanina absorver mais no vermelho que no infravermelho como pode ser visto no espectro de absorção da melanina na figura 2.2. Para o grupo 3 o comportamento não pôde ser verificado devido ao pequeno tamanho da amostra.

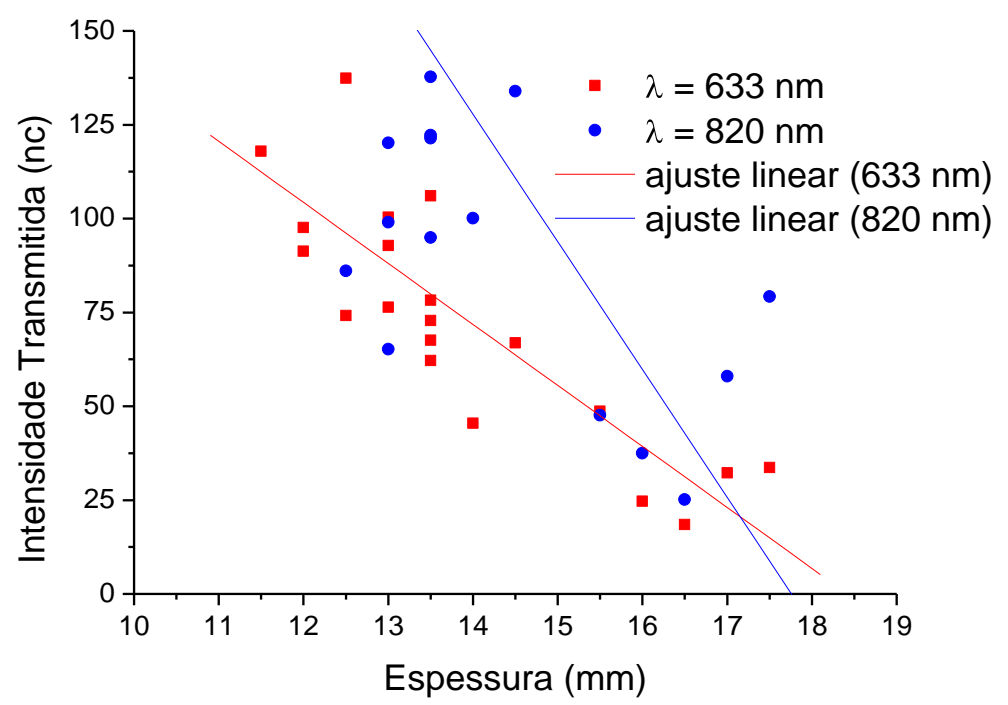

Figura 3.33: Intensidade transmitida pelos dedos do Grupo 1 (em cima), grupo 2 (meio), e grupo 3 (em baixo) $\operatorname{com} \lambda=633 \mathrm{~nm}$ e $\lambda=820 \mathrm{~nm}$. (continua) 

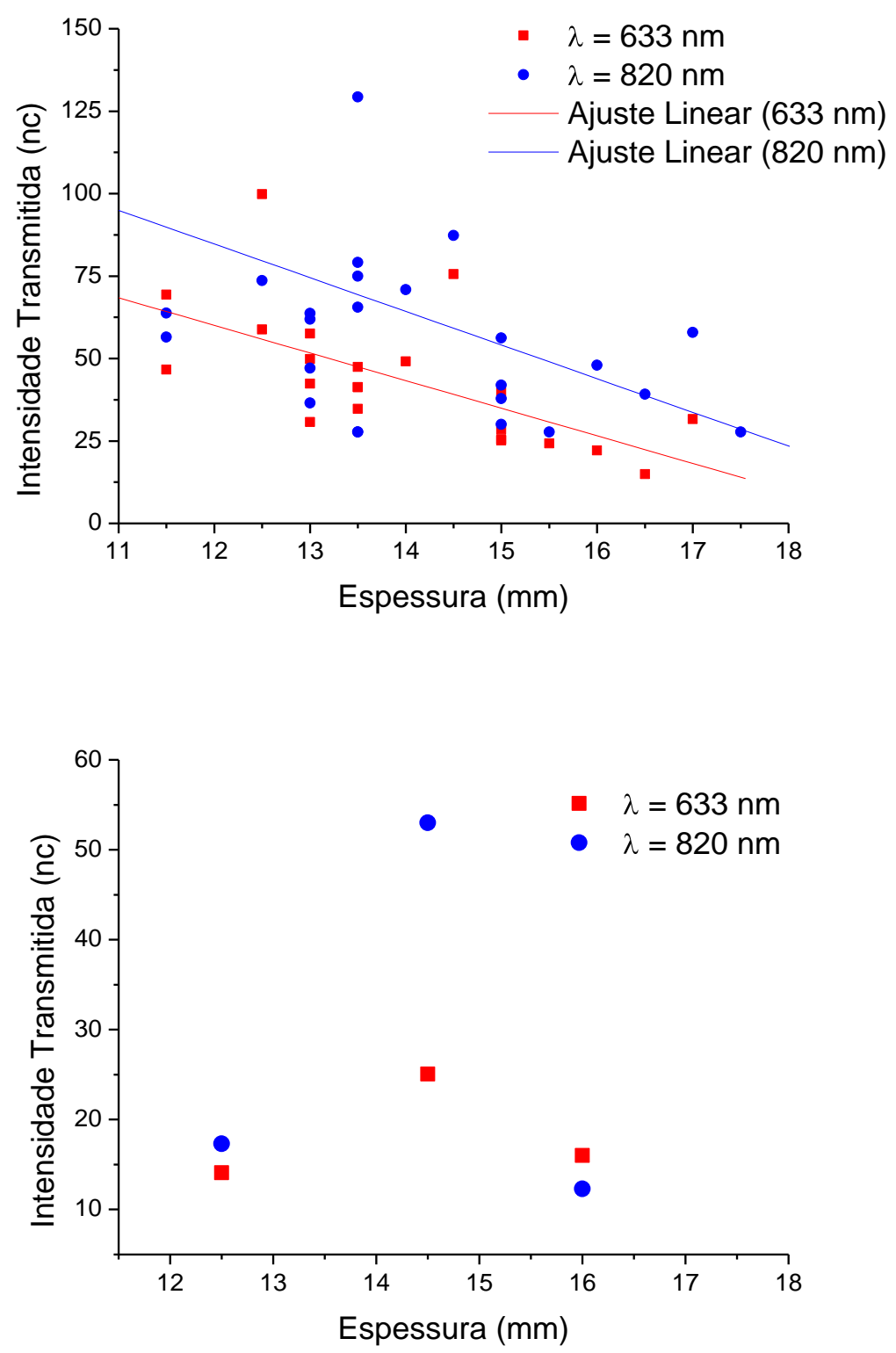

Figura 3.33: Intensidade transmitida pelos dedos do Grupo 1 (em cima), grupo 2 (meio), e grupo 3 (em baixo) $\operatorname{com} \lambda=633 \mathrm{~nm}$ e $\lambda=820 \mathrm{~nm}$.

\subsubsection{Análise Qualitativa:}

Nessa seção serão analisadas de forma mais pormenorizada as imagens de luz transmitida pelos seis dedos. Esses dedos foram escolhidos, pois representam os seguintes casos: A) Dedo pequeno do grupo 1; B) Dedo pequeno do grupo 2; C) Dedo pequeno do Grupo 3; D) Dedo grande do grupo 
1; E) Dedo grande do grupo 2; F) Dedo grande do grupo 3. A espessura dos dedos $A, B$ e $C$ é $12,5 \mathrm{~mm}$, a espessura dos dedos $D$ e $E$ é $17,0 \mathrm{~mm}$ e do dedo F é $16 \mathrm{~mm}$.

As imagens da luz transmitida através dos dedos podem ser vistas na figura 3.34 .

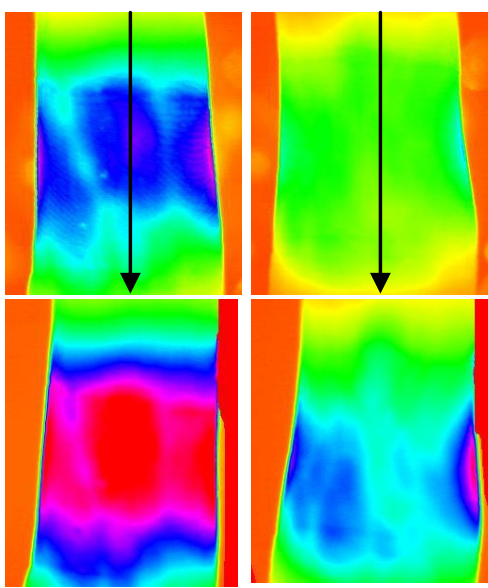

Figura 3.34: Imagens da luz transmitida através dos dedos. As imagens aparecem da esquerda para a direita de $A$ até $F ; \lambda=633 \mathrm{~nm}$ em cima e $\lambda=820 \mathrm{~nm}$ embaixo.

Comparando as imagens fica claro que a luz no infravermelho (laser diodo $\lambda=820 \mathrm{~nm}$ ) atravessa os dedos com maior intensidade que a no vermelho (laser $\mathrm{HeNe} \lambda=633 \mathrm{~nm}$ ). As maiores intensidades geralmente acontecem no centro do dedo, pois esse é o local da incidência do feixe, mas podemos notar intensidades altas também na lateral dos dedos, isso ocorre por que essa região é menos espessa do que o centro do dedo, portanto o caminho óptico é menor e a probabilidade de interação se torna menor. Nessa figura a distribuição isotrópica em torno do centro de iluminação, correspondendo a perfil aproximadamente gaussiano, que era uma regra geral para as amostras de simuladores, não é mais obtida em todas as direções. Isso se deve à geometria aproximadamente cilíndrica dos dedos, que faz com que as espessuras variem muito com a posição. Em alguns casos o perfil da luz 
transmitida, na direção indicada pelas setas nas imagens da figura 3.34, ainda é possível verificar um perfil aproximadamente gaussiano (figura 3.35).

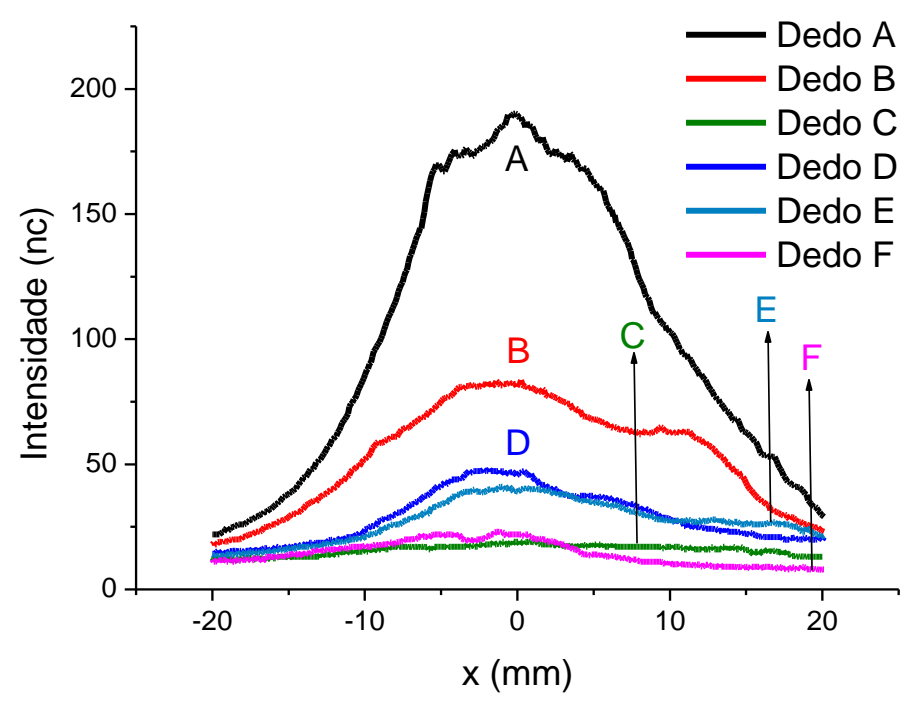

Figura 3.35: Perfil da luz transmitida através dos dedos de $A$ até $F$, nas direções das setas indicadas na figura $3.32(\lambda=633 \mathrm{~nm})$.

Podemos facilmente notar que a intensidade é maior em A que em B que por sua vez é maior que em $\mathrm{C}$, mesmo esses dedos tendo a mesma espessura. Esse comportamento é explicado pela maior absorção de luz em peles mais escuras, ou seja, com maior concentração de melanina.

Comparando A com D, B com E, e C com F vemos que o aumento da espessura do dedo leva a uma diminuição da intensidade transmitida, pois 0 aumento do caminho óptico possibilita a interação do feixe de laser com um número maior de centros espalhadores e / ou absorvedores.

\subsection{Simuladores de Dedo:}

Os resultados apresentados até aqui levaram a um melhor entendimento das características ópticas dos materiais e dos tecidos biológicos estudados. A 
partir de comparações feitas entre os materiais e os tecidos biológicos foi possível escolher quais materiais devem ser usados para melhor simular cada tecido.

Os resultados apresentados até aqui deixam claro que:

1) Tons de pele mais escuros absorvem mais a luz.

2) $O$ coeficiente de absorção é maior para $\lambda=633 \mathrm{~nm}$ que para $\lambda=820 \mathrm{~nm}$.

3) O principal fator de atenuação no tecido adiposo é o espalhamento.

4) O principal fator de atenuação no músculo é a absorção.

Segundo Roggan e colaboradores (1985), o tecido ósseo, para comprimentos de onda no vermelho, tem os seguintes parâmetros ópticos: $\mu_{\mathrm{a}}=1,3 \mathrm{~cm}^{-1} ; \mu_{\mathrm{s}}=190 \mathrm{~cm}^{-1}$ e $\mathrm{g}=0,87$ por isso podemos dizer que o principal fator de atenuação para o tecido ósseo é o espalhamento.

Comparando os perfis das intensidades transmitidas por $2 \mathrm{~mm}$ de parafina e de pele de suíno verificamos que ambas difundem a luz de forma semelhante (figura 3.36). Portanto, a parafina é um bom material para simular a pele. $\mathrm{O}$ tecido adiposo será simulado pela amostra de resina com $10 \%$ de $\mathrm{Al}_{2} \mathrm{O}_{3}$ alfa, pois este material nessa concentração espalha a luz praticamente da mesma forma que o tecido adiposo (figura 3.37). 


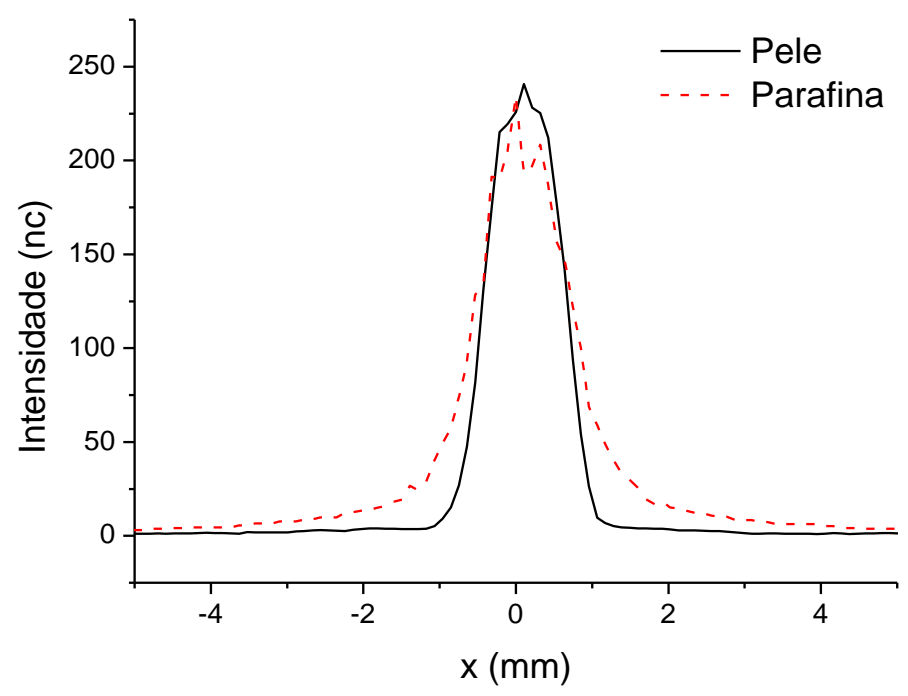

Figura 3.36: Comparação entre os perfis de transmissão por pele de suíno e parafina.

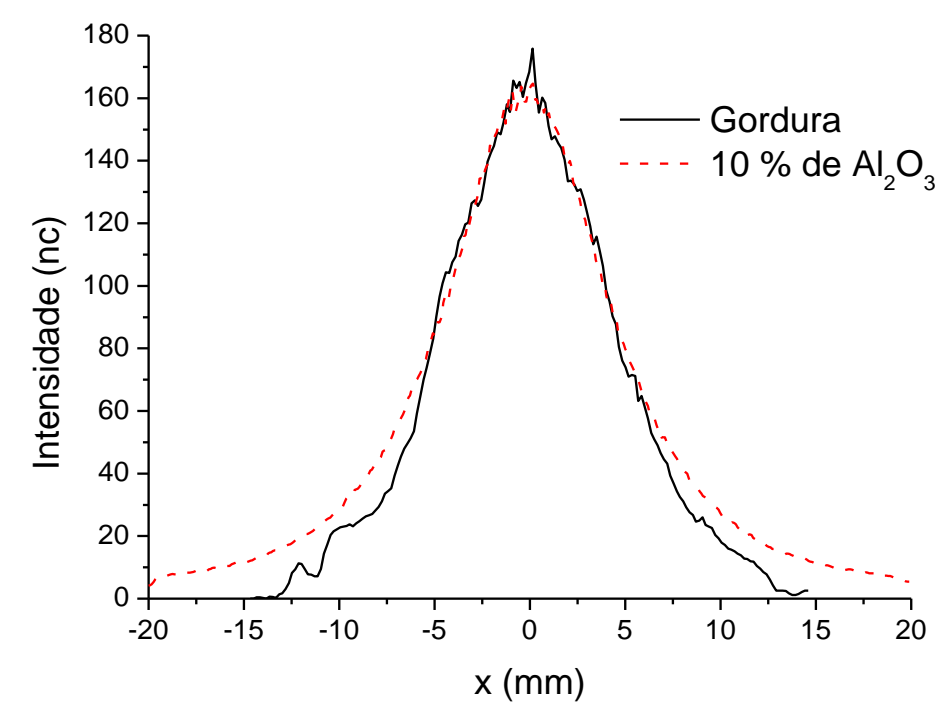

Figura 3.37: Comparação entre os perfis de transmissão por tecido adiposo de suíno e amostra de resina com $10 \%$ de $\mathrm{Al}_{2} \mathrm{O}_{3}$ como espalhador.

Os simuladores de dedo foram construídos em duas partes. A interna é constituída de um cilindro que simula os tecidos internos: osso, músculo, tecido adiposo, etc. e a externa que é uma casca cilíndrica que simula a pele. As diferenças na intensidade transmitida devido a diferenças de espessura dos dedos foram bastante significativas, por isso foram feitos simuladores em duas 
espessuras. Uma das espessuras é $14,0 \mathrm{~mm}$, pois, esta é a média das espessuras dos dedos. A outra espessura dos simuladores é 18,0 mm, que é maior do que qualquer espessura de dedo medida para esse trabalho. Essa espessura foi escolhida para analisarmos melhor os efeitos das diferenças nas espessuras dos dedos.

A parte cilíndrica tem $10 \mathrm{~mm}$ de diâmetro no menor dedo simulado e 14 mm de diâmetro no maior; a casca cilíndrica tem $2 \mathrm{~mm}$ de espessura em ambos os casos. A parte interna é feita de resina com $\mathrm{Al}_{2} \mathrm{O}_{3}$ alfa como espalhador e tinta preta para resina como absorvedor. Para a confecção dessa parte do simulador foram usadas as medidas mostradas na tabela 3.1. Foram feitas 8 dessas partes cilíndricas, 4 das pequenas e 4 das grandes, todas a partir da mesma preparação de materiais da tabela 3.1.

Tabela 3.1 Composição da parte interna do simulador.

\begin{tabular}{|c|c|c|}
\hline Material & Massa $(\mathrm{g})$ & Proporção (\%) \\
\hline Resina de Poliéster & $65,5(1)$ & 79,9 \\
\hline Monômero de estireno & $6,6(1)$ & 8,0 \\
\hline Al2O3 alfa & $8,2(1)$ & 10,0 \\
\hline Tinta & $0,100(4)$ & 0,1 \\
\hline Endurecedor Mek & $1,600(64)$ & 2,0 \\
\hline Total & 82,0 & 100,0 \\
\hline
\end{tabular}

A parte externa é feita de parafina, pois esse é o material que melhor simula a pele. As observações das imagens da luz transmitida através dos dedos nos mostram que a cor da pele (concentração de melanina) influencia fortemente a absorção da luz. Para simular esse efeito adicionamos tinta à parafina.

Os espectros de absorção de tintas de várias cores (figura 3.38) foram comparados ao espectro de absorção da melanina artificial (figura 2.2) Nenhuma cor isoladamente conseguiu ter espectro semelhante à melanina, no 
entanto a mistura das tintas castanho claro, castanho escuro e azul, na proporção $6: 4: 3$, resultou em um espectro que se assemelha ao da melanina (figura 3.39). Portanto, para construirmos a "pele" do simulador, adicionamos essa mistura de tintas à parafina.

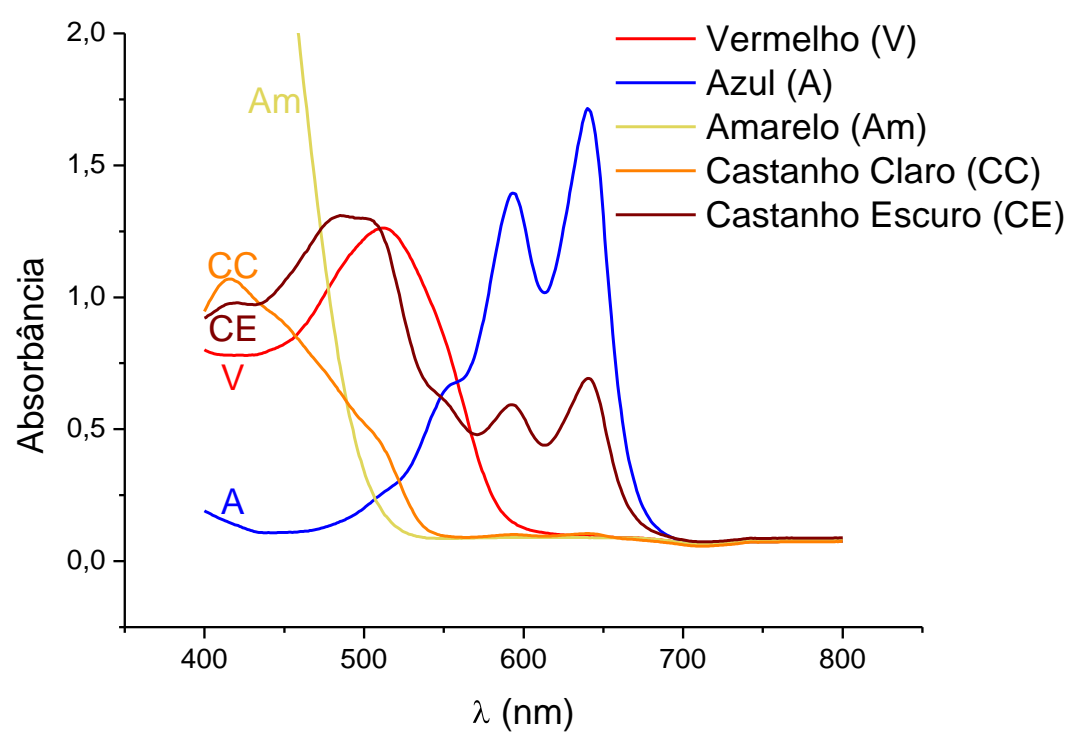

Figura 3.38: Espectro de absorção das tintas para parafina.

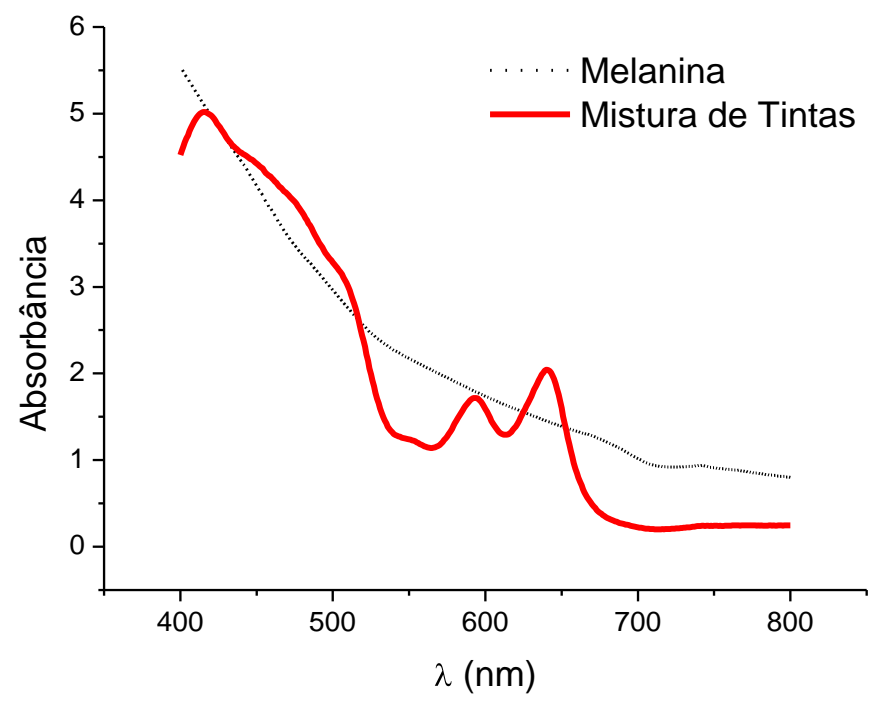

Figura 3.39: Comparação entre os espectros de absorção da melanina e da mistura de tintas. 
Foram feitos 6 tipos de simuladores com as mesmas características dos dedos de $A$ até $F$, como pode ser visto na tabela 3.2. Os simuladores podem ser vistos na figura 3.40 .

Tabela 3.2: Tipos de Simuladores.

\begin{tabular}{|c|c|c|}
\hline Simulador & Diâmetro $(\mathrm{mm})$ & Parte Externa \\
\hline SA & 14 & Concentração baixa de tinta \\
\hline SB & 14 & Concentração média de tinta \\
\hline SC & 14 & Concentração alta de tinta \\
\hline SD & 18 & Concentração baixa de tinta \\
\hline SE & 18 & Concentração média de tinta \\
\hline SF & 18 & Concentração alta de tinta \\
\hline
\end{tabular}

PARTE INTERNA PEQUENA

SA

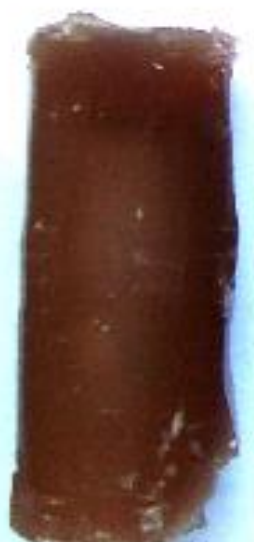

SD

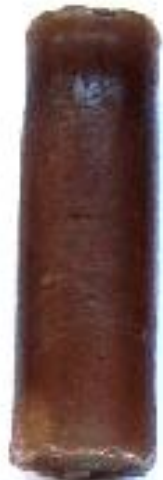

SB

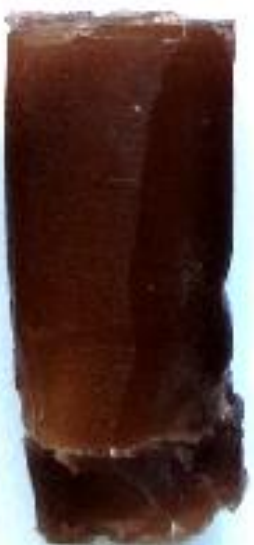

SE

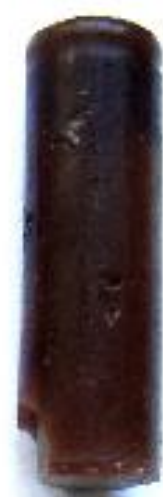

$\mathrm{SC}$

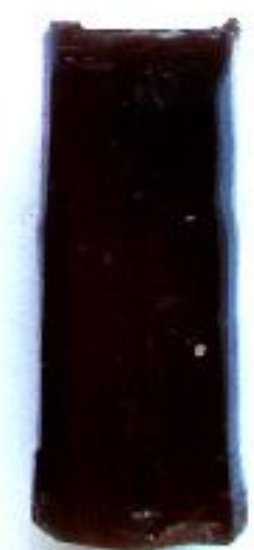

SF

GARTE IN

Figura 3.40: Simuladores. 
As imagens da luz transmitida através dos simuladores podem ser vistas na figura 3.41. Os perfis de transmissão através dos simuladores na direção indicada pelas setas na figura 3.41 podem ser vistos na figura 3.42. Esses perfis são aproximadamente gaussianos e isso mostra a homogeneidade do material.
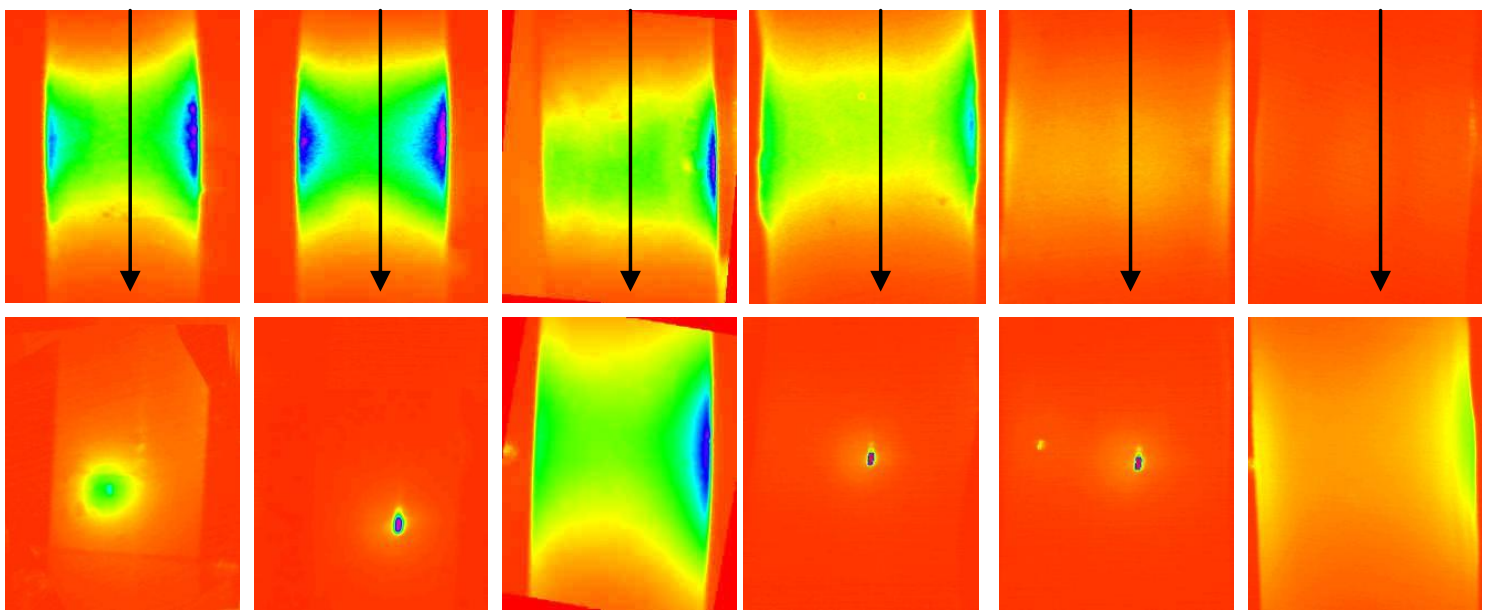

Figura 3.41: Imagens da luz transmitida pelos simuladores. As imagens aparecem, da esquerda para a direita, de SA até SF; $\lambda=633 \mathrm{~nm}$ em cima e $\lambda=820 \mathrm{~nm}$ em baixo.

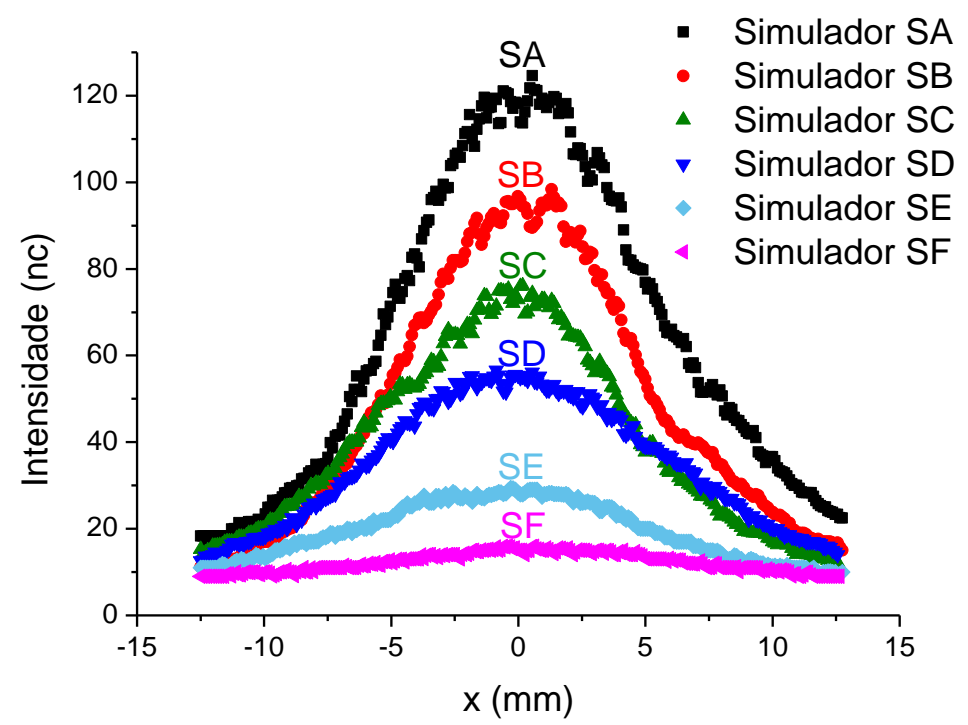

Figura 3.42: Perfil de intensidade transmitida pelos simuladores, para $\lambda=633 \mathrm{~nm}$. 
Esses perfis são mais bem comportados que os de dedo, isso é muito útil para reproduzir e / ou adaptar protocolos dosimétricos. Comparando $\mathrm{I}_{\mathrm{M}}$, w e área sob as curvas, vemos que os simuladores funcionam bem para a maioria dos casos (figura 3.43).
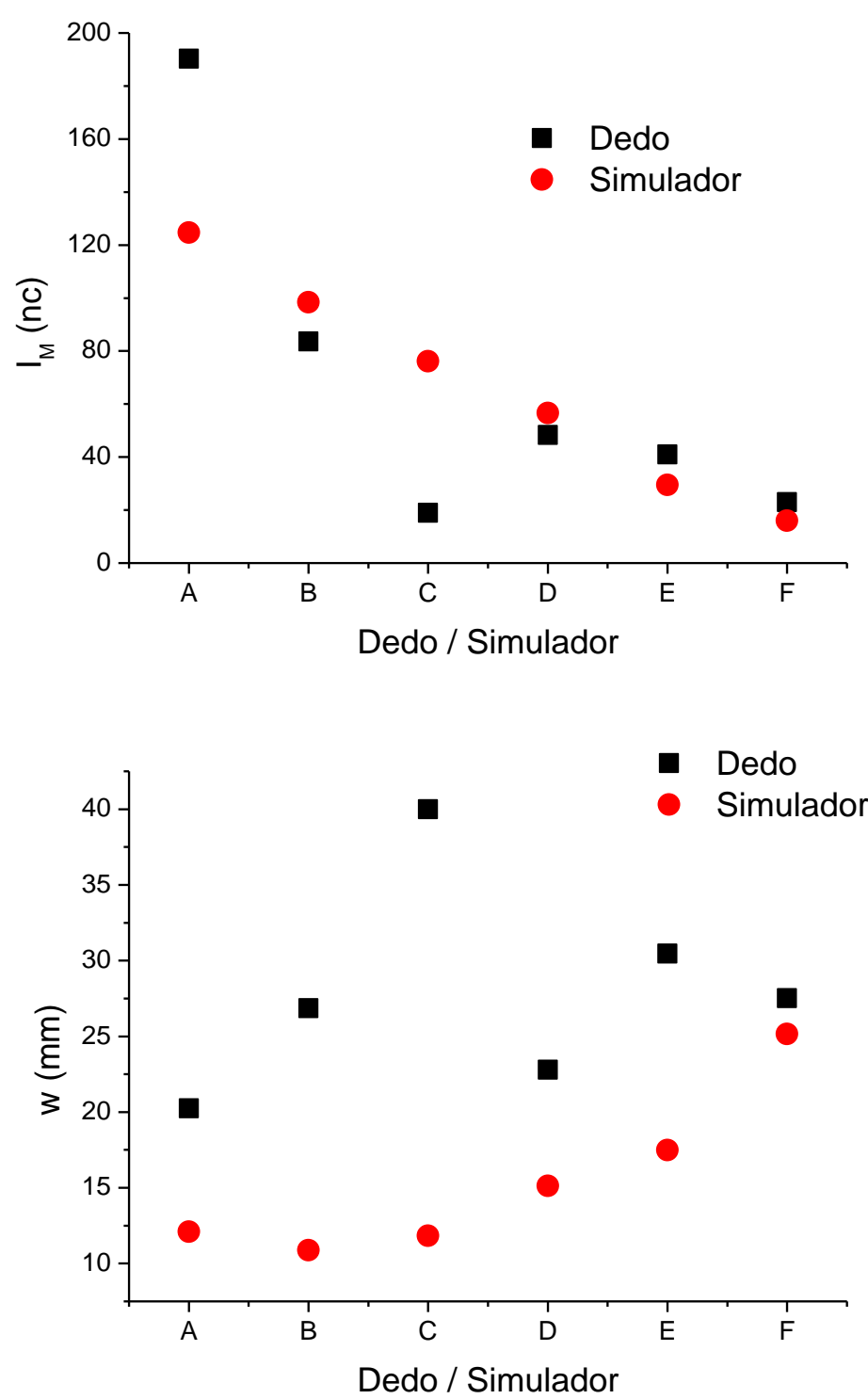

Figura 3.43: Comparação entre $I_{M}$, w e área dos perfis dos dedos de $A$ até $F$ e dos simuladores de SA até SF. (continua) 


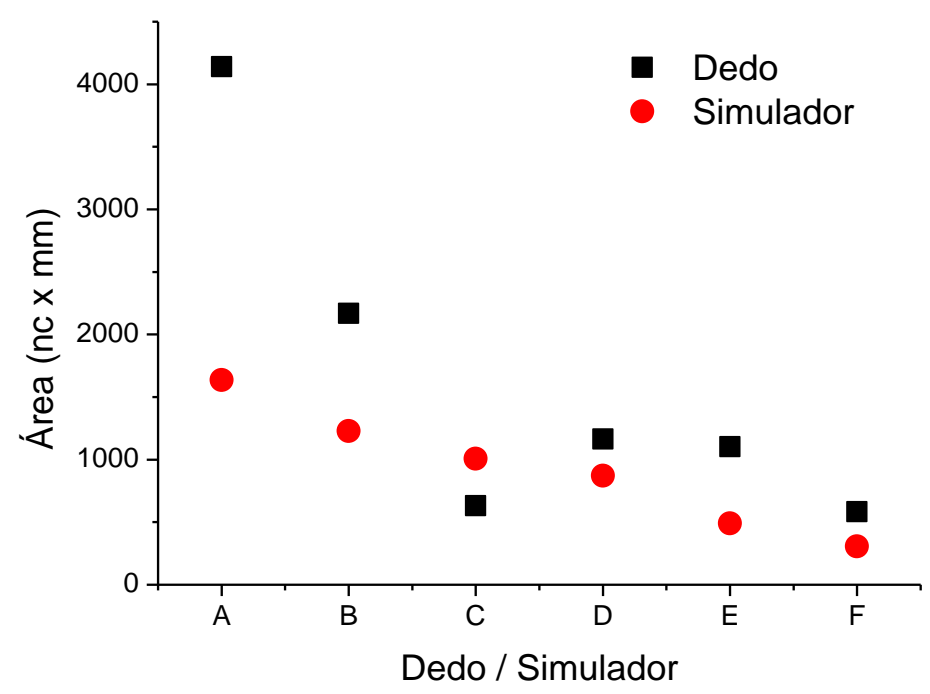

Figura 3.43: Comparação entre $I_{M}$, $w$ e área dos perfis dos dedos de $A$ até $F$ e dos simuladores de SA até SF.

A intensidade máxima coincide para a maioria dos casos. Os dedos $\mathrm{A}$ e C são os que apresentam maior disparidade, isso se deve principalmente por serem casos extremos de pele muito clara (A) e pele muito escura (C).

A largura do perfil foi sempre maior nos dedos do que nos simuladores isso se deve em parte a geometria do dedo, um cilindro achatado, levemente diferente da geometria do simulador. Outro fator que faz $w$ ser maior para os dedos é que a curva para eles não é bem comportada e apresentam múltiplos picos que reduzem a acurácia da medida de $\mathrm{w}$. A baixa intensidade transmitida faz com que não apareçam picos no perfil, isso invalida a medida de w para C e superestima as medidas para F e SF.

A área sob as curvas fornece uma estimativa da intensidade total que atravessa a amostra e é proporcional a $I_{\mathrm{M}} \mathrm{e}$ a $\mathrm{w}$. A área é muito maior em $\mathrm{A}$ do que em SA, pois os valores de $\mathrm{I}_{\mathrm{M}} \mathrm{e} \mathrm{w}$ de A são superestimados como já foi dito. 
Comparando a intensidade média transmitida através dos dedos de $\mathrm{A}$ até $\mathrm{F}$ e seus respectivos simuladores de $\mathrm{SA}$ até SF fica claro que os simuladores têm as seguintes características semelhantes aos dedos:

1) A intensidade transmitida diminui com a espessura no simulador assim como no dedo.

2) A intensidade transmitida diminui com a concentração de absorvedor: melanina, nos dedos; e a mistura de tintas, nos simuladores (figura 3.43).
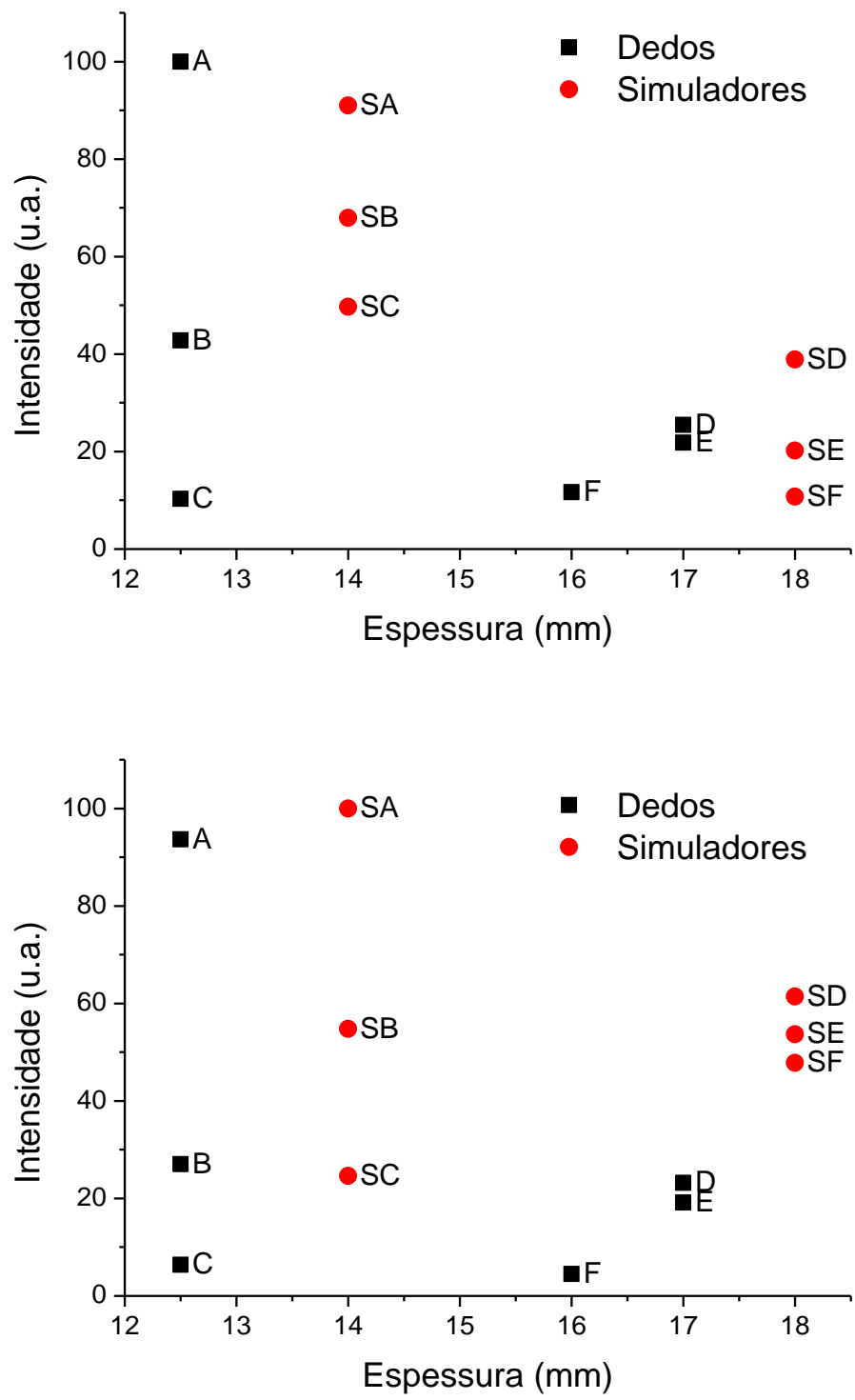

Figura 3.44: Intensidade transmitida pelos dedos e simuladores para $\lambda=633 \mathrm{~nm}$ (em cima) e $\lambda=820 \mathrm{~nm}$ (em baixo), normalizados para que a intensidade máxima seja 100. 


\section{Conclusão:}

Os experimentos apresentados nesse trabalho nos permitiram conhecer melhor as características ópticas de tecidos biológicos como pele, tecido adiposo e músculo. Esses conhecimentos foram a peça fundamental para o desenvolvimento de simuladores ópticos que mimetizam dedos humanos.

A melanina artificial diluída em água a uma concentração de $125 \mu \mathrm{g} / \mathrm{mL}$ foi iluminada por dois feixes de laser $(\lambda=633 \mathrm{~nm}$ e $\lambda=820 \mathrm{~nm})$, e a partir da absorção causada pela amostra foi possível concluir que para $\lambda=633 \mathrm{~nm}$ $\mu_{\mathrm{a}}=3,12 \mathrm{~cm}^{-1}$ e para $\lambda=820 \mathrm{~nm}, \mu_{\mathrm{a}}=1,16 \mathrm{~cm}^{-1}$.

O perfil de intensidade da luz transmitida através de amostras essencialmente espalhadoras como as de resina com partículas de $\mathrm{Al}_{2} \mathrm{O}_{3}$ alfa, $\mathrm{Al}_{2} \mathrm{O}_{3}$ gama e microesferas de vidro é aproximadamente gaussiano. A intensidade transmitida por essas amostras tende a diminuir com o aumento da concentração de partículas o que era esperado, pois com uma concentração maior aumenta a probabilidade de espalhamento.

Para as amostras que têm $\mathrm{Al}_{2} \mathrm{O}_{3}$ alfa como espalhador a largura do perfil de intensidade transmitida aumenta com a concentração de espalhadores para concentrações baixas, pois a probabilidade de espalhamento aumenta. Mas chega à máxima largura para concentração de $15 \%$ de $\mathrm{Al}_{2} \mathrm{O}_{3}$. Para concentrações mais altas há uma tendência de redução da largura, o que indica que a amostra está se tornando opaca.

Para as amostras que têm $\mathrm{Al}_{2} \mathrm{O}_{3}$ gama como espalhador a largura do perfil de intensidade transmitida, na faixa de concentrações ensaiadas, sempre 
tende a aumentar indicando aumento da probabilidade de interação sem chegar ao limite de opacificar a amostra.

Os perfis de luz espalhada a $90^{\circ}$ pelas amostras de resina que têm $\mathrm{Al}_{2} \mathrm{O}_{3}$ alfa como espalhador mostram rápido crescimento da intensidade seguida de queda assintoticamente exponencial. A intensidade máxima espalhada a $90^{\circ}$ depende da concentração de espalhadores: inicialmente aumenta com a concentração, pois a chance de espalhamento aumenta com a concentração; para concentrações aumentadas os espalhamentos múltiplos fazem com que a quantidade de fótons que chegam à câmera diminua. Para concentrações maiores o máximo acontece mais próximo da superfície de incidência, isso é explicado porque para concentrações mais altas a chance de ocorrer interação nas primeiras camadas da amostra é muito grande.

Para as amostras que têm ME de vidro como espalhador a largura do perfil de intensidade transmitida, na faixa de concentrações ensaiadas, sempre tende a aumentar com o aumento da concentração, indicando aumento da probabilidade de interação sem chegar ao limite de opacificar a amostra. Esse comportamento é observado tanto para $\lambda=633 \mathrm{~nm}$ quanto para $\lambda=820 \mathrm{~nm}$. A intensidade, para esses dois comprimentos de onda, é atenuada com o aumento da concentração de ME de maneira equivalente, isso mostra que a probabilidade de interação é a mesma para os dois comprimentos de onda. No entanto, a largura do pico é maior para $\lambda=633 \mathrm{~nm}$ o que indica que 0 espalhamento nesse comprimento de onda é mais isotrópico.

A intensidade transmitida diminui para amostras de parafina mais espessas, pois mais fótons serão absorvidos ou difundidos ao atravessar a 
amostra. A largura do perfil de transmissão aumenta com a espessura, pois há maior probabilidade de espalhamento em amostras mais espessas.

Estudamos o espalhamento de luz a $90^{\circ}$ pelas amostras de parafina variando a distância (z) do ponto de incidência do laser à superfície fotografada de 1 até $8 \mathrm{~mm}$. O perfil apresentou o mesmo comportamento que o de espalhamento a $90^{\circ}$ das amostras de resina com $\mathrm{Al}_{2} \mathrm{O}_{3}$ como espalhador. $\grave{A}$ medida que $z$ aumenta maior deve ser o número de fótons que interagem antes de chegar à superfície, e isso faz com que a intensidade máxima fique menor e ocorra em uma profundidade maior; o pico fique mais largo e a atenuação exponencial assintótica se torna mais suave, ou seja, o $\mu_{\mathrm{as}}$ fica menor.

Os perfis de transmissão através das cinco amostras inteiras de tecido suíno revelaram que essas amostras têm alguns comportamentos semelhantes aos das amostras não biológicas como a redução na intensidade transmitida e o aumento da largura do pico do perfil de transmissão quando a amostra é mais espessa. Os perfis de espalhamento a $90^{\circ}$ mostram que cada tecido tem propriedades de absorção e espalhamento distintas dos demais, pois há mudanças perceptíveis no perfil, nas interfaces de tecidos.

Analisando pele, tecido adiposo e músculo de suíno foi possível obter informações sobre as propriedades de atenuação desses tecidos. Entre elas podemos citar:

1) A luz se difunde ao atravessar a pele.

2) O tecido adiposo é muito espalhador.

3) A atenuação no tecido muscular acontece principalmente por absorção e espalhamento frontal. 
Medidas realizadas com dedos humanos revelaram que a cor da pele e a espessura do dedo têm relevância fundamental para a atenuação da luz. Nas pessoas de peles mais claras a intensidade transmitida através dos dedos foi muito maior que nas pessoas de peles mais escuras. Nos grupos de pessoas com peles mais claras e tons intermediários foi observado a redução na intensidade transmitida conforme os dedos ficavam mais espessos; esse comportamento não foi verificado nas peles mais escuras, pois, para essas, o principal fator de atenuação é a absorção causada pela melanina. $O$ comprimento de onda utilizado no infravermelho $(\lambda=820 \mathrm{~nm})$ é mais penetrante que o vermelho $(\lambda=633 \mathrm{~nm})$.

Foram confeccionados simuladores feitos com parafina e tintas, para imitar a pele; e de resina com $\mathrm{Al}_{2} \mathrm{O}_{3}$ alfa, para mimetizar os tecidos internos dos dedos. Eles são de seis tipos para imitar três tons de pele e duas espessuras. Comparando esses simuladores com dedos percebemos que eles apresentam as mesmas tendências de redução na intensidade com o aumento da espessura e da concentração de absorvedores. Esses simuladores podem ainda ser aperfeiçoados no formato anatômico e na mistura de tintas, mas são um bom ponto de partida para phantoms ópticos.

Os simuladores funcionaram bem e poderão ser usados efetivamente na prática clínica para a otimização, adaptação e desenvolvimento de dosimetria para LBI e PDT. 


\section{Referências:}

Baptista IMC, “Análise do efeito do laser de baixa potência na prevenção da deiscência incisional em cirurgia cardíaca", Dissertação (Mestrado em Engenharia Biomédica) - Universidade do Vale do Paraíba, 2003.

Basford JR, "Low-energy laser therapy: controversies and new research findings". Lasers Surg. Med; 9(1):1-5, 1989.

Bjordal JM, Couppe C, Chow RT, et al. "A systematic review of low level laser therapy with locationspecific doses for pain from chronic joint disorders". Australian Journal of Physiotherapy, 49(2) 107-116, 2003.

Boulnois JL, "Photophysical processes in recent medical laser developments: a review." Lasers Med. Sci. 1: 47-66, 1986.

Bowes LE, Nouri K, Berman B, Jimenez G, Pardo R, Rodriguez L, Spencer JM. "Treatment of pigmented hypertrophic scars with the $585 \mathrm{~nm}$ pulsed dye laser and the $532 \mathrm{~nm}$ frequency-double Nd:Yag laser in the Q-switched and variable pulse modes: a comparative study.” Dermatol. Surg.; 28(8): 714-9, 2002.

Brosseau L, Welch V, Wells G, Tugwell P, De Bie R, Gam A, Harman K, Shea B, Morin M. "Low level laser therapy for osteoarthritis and rheumatoid arthritis: a metaanalysis". J. Rheumatol; 27(8):961-969, 2000 .

Chavantes MC (editora), "Laser em bio-medicina”, Atheneu, 2009.

Cheong W, Prahl SA, Welch AJ, "A review of the optical properties of the biological tissues", Jornal of Quantum Eletronics, 26 (12): 2166 - 2185, 1990.

Dortbudak O, Haas R, Mailath-Pokorny G, "Effect of low-power laser irradiation on bony implant sites". Clinical Oral Implants Research; 13(3): 288-292, 2002.

Einstein A, "Zur Quantum Theorie der Bremsstrahlung", Deutsch Physik Ges., 1916. Apud Chavantes MC (editora), "Laser em Bio-medicina", Atheneu, 2009.

Finsen N, "La Phototherapie", Medicinske Lysinstitut de Copenhague, 1899. Apud Karu TI, "Photobiology of low-power laser therapy", Harwood Academic Publishers, 1989.

Flock ST, Wilson BC, Patterson MS, "Total attenuation coefficients and scattering phase function of tissues and phantom materials at 633 nm”, Medical Physics, 14: 835 - 841, 1987.

Gorbachewich E, "The influence of Rays of Different Colors on the growth and development of mammals", 1883. Apud Karu TI, "Photobiology of low-power laser therapy", Harwood Academic Publishers, 1989.

Guzzardella GA, Tigani D, Torricelli P, et al. "Low-power diode laser stimulation of surgical osteochondraldefects: Results after 24 weeks". Biotechnology; 29(3): 235-244, 2001.

Ishimaru A, "Wave Propagation and scattering in Radom Media", Academic Press, 1968.

Karu TI, "Molecular mechanism of the therapeutic effect of low-intensity laser radiation", Laser in life science, 1988.

Karu TI, "Photobiology of low-power laser therapy", Harwood Academic Publishers, 1989.

Karu TI, "Photobiology of Low-Power Laser Effects. Health Physics”; 56: 691-704, 1989. 
Katzir A, "Laser and optical fibers in medicine", Academic Press, 1993.

Kerker M, “The scattering of light”, Academic Press, 1969.

Klimenko IT, Shuvalova IN, "Low intensity laser radiation in complex therapy of patients with vascular obliterating atherosclerosis of low extremities.” Lik. Sprava; 8: 98-102, 2002

Machado AE, "Terapia fotodinâmica: princípios, potencial de aplicação e perspectivas”, Química Nova, 23(2), 2000.

Magacho T, "Nova possibilidade terapêutica menos invasiva no tratamento de estenose traqueal através do efeitobiomodulador do laser de baixa potência". Dissertação (Mestrado em Engenharia Biomédica) Universidade do Vale do Paraíba, 2005.

Maiman T, “Stimulated optical radiation in ruby”, Nature, 187 (4736): 493 - 4941960.

Mester AF, Mester A, "Clinical-data of laser biostimulation in wound-healing." Lasers in Surgery and Medicine; 7(1): 78-78, 1987

Mester E, Jasz agy-Nagy, "The effect of laser radiation on wound healing and collagen synthesis", Stud. Biophysics, 5: 227 - 234, 1973.

Mie G, "Beitrige zur Optik truber Medien, speziell kolloidaler Metallsungen," Ann Phys. (Leipzig) 25, 376-445, 1908. Apud Karu TI, "Photobiology of low-power laser therapy", Harwood Academic Publishers, 1989.

Niemz M, “Laser-Tissue Interactions”, Springer, 2004.

Ohshiro T, Calderhead RG. "Progress in laser therapy". John Wiley, 1991.

Ozawa Y, Shimizu N, Kariya G, Abiko Y, "Low-energy laser irradiation stimulates bone nodule formation at early stages of cell culture in rat calvarial cells", Bone; 22(4): 347-54, 1995

Petrek M, Hubácek J, Ordeltová, "Immunomodulatory effects of Laser therapy in the treatment of chronic tonsillitis.” Acta Univ. Olomuc. Fac. Med; 129: 119-26, 1991.

Perkowitz, "From ray-gun to Blu-ray”, Physics World, 23 (5): 16-20, 2010.

Pinto NC, Chavantes MC, Stolf NAG, "Prevent complications in cardiovascular surgery: a successful method applying low level laser therapy”. Lasers Surgery Medicine; 40:61, 2008.

Pogue B, Patterson MS, "Review of tissue simulating phantoms for optical spectroscopy, imaging and dosimetry", Journal of Biomedical Optics, 11(4), 041102, 1-16, 2006.

Prahl SA, "Light transport in tissue", Ph.D. dissertation, Univ. Texas, Austin,1988.

Ramos A, et al, "Monte Carlo simulations combined with experimental measurements: a new possibility of study of the light distribution in fat emulsions.", proceedings SPIE 7567, 756709 2010.

Roelandts, "The history of phototherapy: Something new under the sun?", Journal of the American Academy of Dermatology, 46(6): 926-930, 2002.

Roggan A, et al, "Experimental set-up and Monte-Carlo model for the determination of optical tissue properties in the wavelength range $330-1100$ nm.” Proc. SPIE 2323, 21-36, 1995.

Saito M, et al, "Difusão de luz em tecidos biológicos", anais do XIV Congresso Brasileiro de Física Médica, 2009 
Saito S, Shimizu N, "Stimulatory effects of low power laser irradiation on bone regeneration in midpalatal suture during expansion in the rat". American Journal of Orthodontics and Dentofacial Orthopedics; 111:525-532, 1997

Shulakova IN et al. "The efficacy of low-intensity laser radiation in the treatment of arterial hypertension complicated by isquemic heart disease”. Vopr. Kurortol. Fizioter. Lech. Fiz. Kult; 4: 3-6 2001

Sliney DH, "Radiometric Quantities and Units Used in Photobiology and Photochemistry: Recommendations of the Commission Internationale de l'Eclairage (International Commission on Illumination)" Photochemistry and Photobiology, 83: 1-8, 2007

Sugrue ME, Carolan J, Leen EJ. "The use of infra-red laser therapy in the treatment of venous ulcerations". Annals of Vascular Surgery"; 4: 179-181, 1990.

Tagliabule P, et al. "Use of low-potency lasers in plastic surgery”. Minerva Med; 75(5): 177-84, 1984.

Tam G, “Low Power Laser Therapy and Analgesic Action”. J Clin Laser Med Surg; 17(1): 29-33, 1999.

Trelles MA, Mayayo E, "Bone-fracture consolidates faster with low-power laser". Lasers in Surgery and Medicine, 7(1): 36-45, 1987.

Von Tappeiner, "Uber die wirkung fluorescierender Stoffe auf Infusorien: nach Versuchen von O. Raab." 1900. Apud: Babilas, et al. "Photodynamic therapy in dermatology: state-of-the-art". Photodermatology, Photoimmunology \& Photomedicine 26, 118-132. 2010

Watmough DJ, "Diaphanography: mechanism responsible for the images" Acta Radiol. Oncol. 21 (1), 11 15, 1982.

Wilksch PA, Jacka F, Blake AJ, "Studies of light propagation in tissue", in Porphyrin Localization and Treaament of Tumors, Dorion DR e Gomer CJ, Eds. New York 1984 Alan R Liss, pp. 149-161, 1984.

Yoshimura EM, Itri R, “Dosimetria na Terapia Fotodinâmica”, Jornal Brasileiro de Laser. 1, 2007. 